\title{
ESTUDO DA DISTRIBUIÇÃO \\ DE UMA BASE DE DADOS APOIADA \\ NO MODELO DE REPRESENTAÇÃO DE OBJETOS
}

\author{
Joāo Eduardo Ferreira
}

Orientaçāo:

Prof.Dr. Caetano Traina Jr.

Dissertação apresentada ao Instituto de Física e Química de São Carlos, USP, para a obtençāo do título de Mestre em Ciências "Física Aplicada".

Departamento de Física e Ciência dos Materiais

São Carlos - 1991

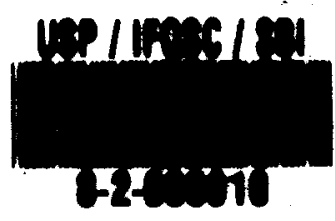


Dedico este trabalho à minha māe, que embora hoje muito distante, sempre esteve e estará presente. 


\section{AGRADECIMENTOS}

Ao Prof.Dr. Caetano Traina Jr., meu orientador e amigo, pela competência e paciência dispensadas para que este trabalho se realizasse, não medindo esforços para auxiliar a superar todas as dificuldades encontradas.

Aos participantes do Grupo de Estudo de Base de Dados ICMSC-USP, que contribuiram para o surgimento e realização de muitas idéias deste trabalho.

À Maria Benedita de Souza (Benê), desenhista do Grupo de Instrumentação e Informática do IFQSC-USP, pela competência e dedicação na elaboraçāo dos desenhos em Autocad apresentados neste trabalho.

Ao DEMAC-IGCE-Unesp Rio Claro, pelo ambiente de trabalho proporcionado, que facilitou em muito a realização deste trabalho.

À CAPES, através do Programa Institucional de Capacitação de Docentes, e ao Instituto de Física e Química de São Carlos pela oportunidade de aprimoramento técnico e científico que me foi oferecida.

A Coordenadoria de Divulgação Científica e Cultural do IFQSC-USP, por ter deixado a disposição os equipamentos necessários para edição deste trabalho.

À Renata Grilli, pela colaboração na estética final do texto e pela gentileza na reserva para utilização dos equipamentos necessários para edição deste trabalho.

A todos os amigos, que direta ou indiretamente, contribuiram com seu apoio e auxilio. Em especial: Dinis, Gilberto, Hilda, Liliane, D.Maria, Maurício, Miled, Noedir, Pedro, Renato, Reginaldo, Roberto, Sergio, Valêncio e Wagner.

Aos meus irmãos Juarez e Joseane, pela amizade e incentivo principalmente nos momentos mais difíceis. Ao meu pai, por ter fornecido as condições económicas para que eu pudesse estudar.

À Regina, pela colaboração na correçāo do texto e por tudo que construímos até hoje, incluindo nossos filhos Vítor e Danilo. 


\section{CONTEÚDO}

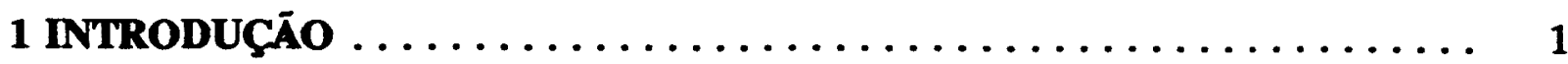

1.1 - Caracterização do Problema .......................... 1

1.2 - Organizaçāo do Trabalho $\ldots \ldots \ldots \ldots \ldots \ldots \ldots \ldots \ldots \ldots \ldots \ldots \ldots$

2 CONTROLE DE CONCORRÊNCIA $\ldots \ldots \ldots \ldots \ldots \ldots \ldots \ldots \ldots, 4$

2.1 - Descrição do Problema ....................... 4

2.2 - Teoria da Serialização ....................... 7

2.2.1 - Execução Serial ....................... 7

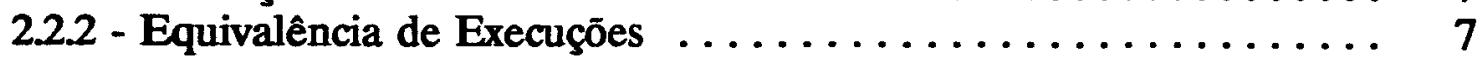

2.2.3 - Execuçōes Serializáveis ..................... 7

2.4 - Teorema da Serialização .................. 8

2.3 - Escalonadores Baseados em Bloqueios . . . . . . . . . . . . 9

2.3.1 - Bloqueios Mútuos (DeadLock) . . . . . . . . . . . 11

2.3.2 - Método de Bloqueio em Duas Fases (2PL) ........... 13

2.3.3 - Métodos de Bloqueio num Ambiente Distribuído ......... 14

2.3.4 - Bloqueios Mútuos no Caso Distribuído ............. 16

2.4 - Escalonadores Baseados em Pré-ordenação ................ 16

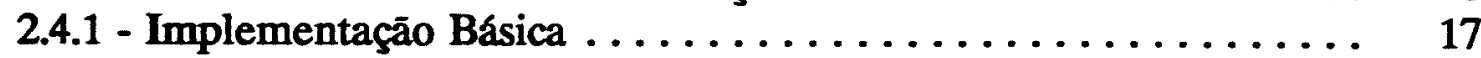

2.4.2 - Implementação Conservativa ................. 19

2.4.3 - Implementação Baseada em Versões Múltiplas ......... 20

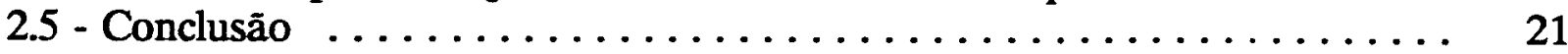

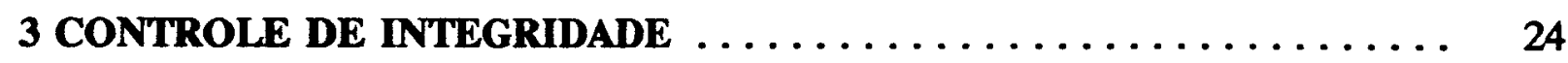

3.1 - Falhas no Sistema de Base de Dados . . . . . . . . . . . . . . 24

3.2 - Mecanismos de Controle de Integridade ................ 27

3.2.1 - Programas Restauradores ................... 27

3.2 .2 - Descargas . . . . . . . . . . . . . . . . . 28

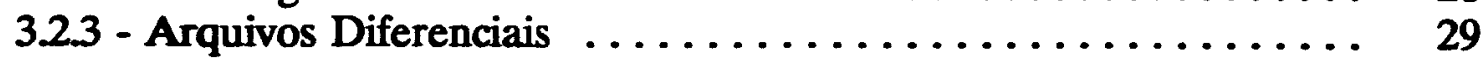

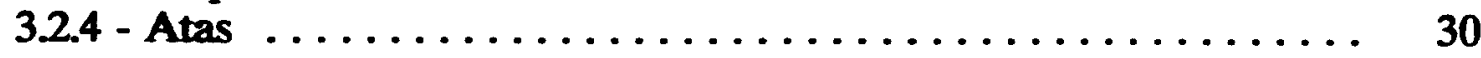

3.2 .5 - Imagens Transientes $\ldots \ldots \ldots \ldots \ldots \ldots \ldots \ldots \ldots \ldots, 31$

3.3 - Protocolo de Bloqueio Bifásico para Comunicações $\ldots \ldots \ldots \ldots \ldots . . \ldots 34$

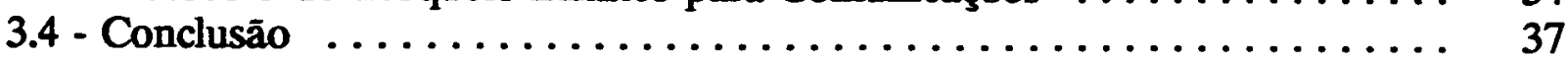


4 O MODELO DE REPRESENTAÇĀO DE OBJETOS

4.1 - Introdução . . . . . . . . . . . . . . . . . . . .

4.2 - Conceitos do Modelo de Representação de Objetos ............

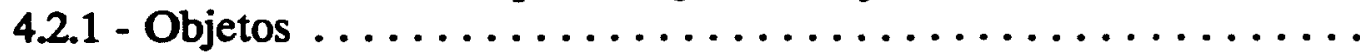

4.2.2 - Relacionamentos .....................

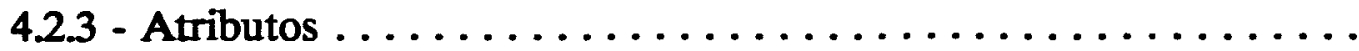

4.2.4 - Colónias de Objetos ....................

4.2.5 - Exemplo de Modelagem do MRO ................

4.2.6 - Relacionametos de Generalização e Sumarização ..........

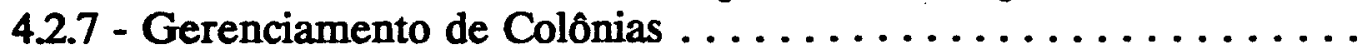

4.3 - O Gerenciador de Objetos (GEO) $\ldots \ldots \ldots \ldots \ldots \ldots \ldots \ldots \ldots$

4.3.1 - GEO Mono-usuário . ...................... 53

4.3.2 - Sistema de Gerenciamento de Memória(SGM) Mono-usuário .. 55

4.3 .3 - GEO Multi-usuário ................... 55

4.3.4 - Sistema de Gerenciamento de Memória Multi-usuário ....... 58

4.3.5 - Sistema de Ger. de Transação do GEO multi-usuário ....... 59

4.4 - Conclusão ............................. 60

5 DISTRIBUIÇĀO DA BASE dE DAdOS APOIADA NO MRO ........ 61

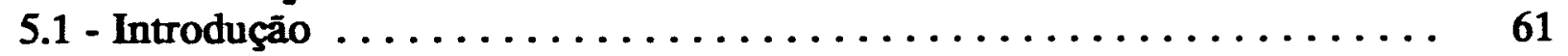

5.2 - Conceitos Envolvidos na Distribuição do MRO ............ 63

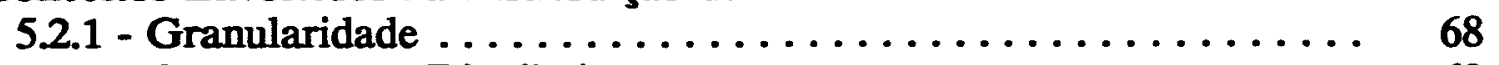

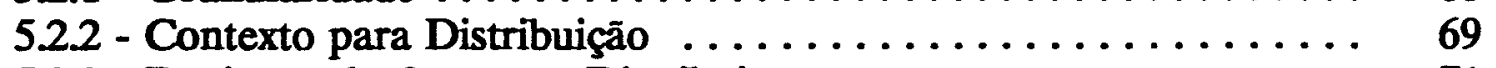

5.2 .3 - Registros da Operaçāo Distribuição .............. 71

5.2.4 - Modelagem da Operação de Distribuição Através do MRO .... 72

5.3 : Operação Distribuição ........................... 74

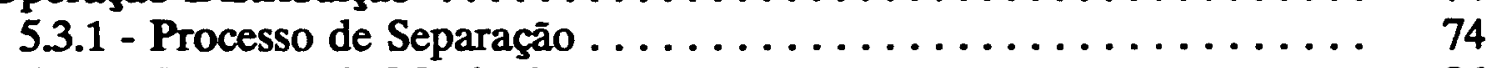

5.3 .2 - Processo de Manipulaçăo .................. 86

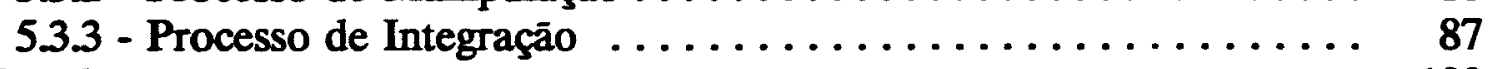

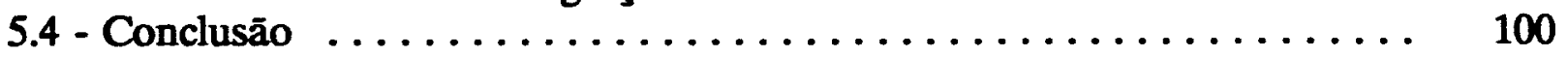

6 DEcisóes de PRojeto, futuras Pesquisas E CONClusões ... 102

6.1 - Decisōes de Projeto . . . . . . . . . . . . . . . . . 102

6.1.1 - Necessidades de Distribuição em Modelos Convencionais e no MRO ........................ 102

6.1.2 - Definição dos tipos de ligação entre bases original e cópia .... 103

6.1.3 - Diferenciação de Objetos da Base Cópia ............. 105

6.1.4 - Relacionamento de Interface .................. 106

6.1 .5 - Relacionamento Triplo .................... 106

6.2 - Futuras Pesquisas .......................... 107

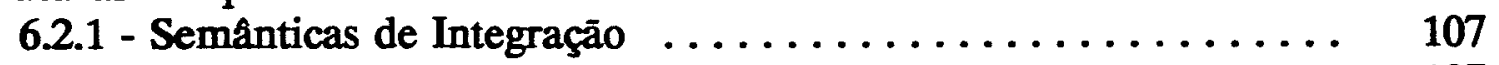

6.2 .2 - Novos tipos de Integração . . . . . . . . . . . . . 107

6.2 .3 - Controle de Integridade na Operação de Integração . . . . . . 108

6.2.4 - Tipo de Ligação "Online" . . . . . . . . . . . . . . . . . 108

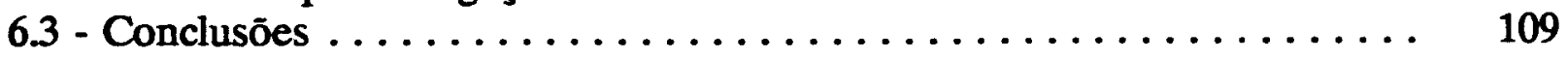

BIBLIOGRAFIA $\ldots \ldots \ldots \ldots \ldots \ldots \ldots \ldots \ldots \ldots \ldots \ldots \ldots \ldots \ldots \ldots \ldots \ldots$ 


\section{LISTA DE FIGURAS}

Fig.2.1: Formas de conectar os nós $\ldots \ldots \ldots \ldots \ldots \ldots \ldots \ldots \ldots \ldots \ldots$. 5

Fig.2.2: Arquitetura de um SGBDDD. $\ldots \ldots \ldots \ldots \ldots \ldots \ldots \ldots \ldots \ldots 6$

Fig.2.3: Grafo de serialização. .................... 8

Fig.2.4: Sequência de transações T1,T2 e T3. ................ 12

Fig.2.5: Dígrafo para T1, T2 e T3. .................. 13

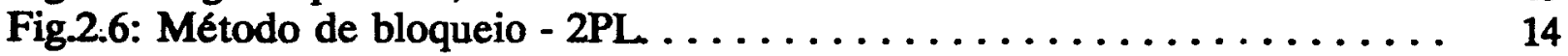

Fig.2.7: Quadro Comparativo do Controle de Concorrência .......... 22

Fig.3.1: Classificação e frequência das falhas ................ 26

Fig.3.2: Diagrama de estados das transaçōes. ............... 27

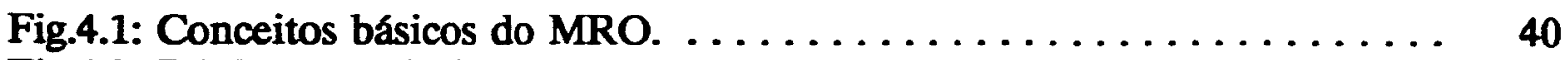

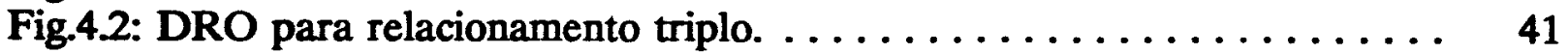

Fig.4.3: Subconjunto do Meta-esquema MRO. .................. 46

Fig.4.4: Experimento de aprisionamento de átomos. ............ 48

Fig.4.5: DRO do experimento de resfriamento de átomos. $\ldots \ldots \ldots \ldots \ldots 48$

Fig.4.6: DRO do relacionamento triplo. ................ 49

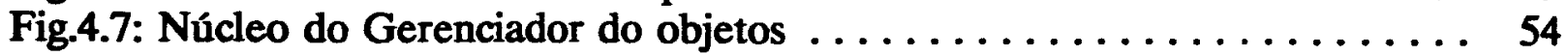

Fig.4.8: Módulos lógicos do GEO mono-usuário $\ldots \ldots \ldots \ldots \ldots \ldots \ldots \ldots$

Fig.4.9: Módulos lógicos do Geo multi-usuário $\ldots \ldots \ldots \ldots \ldots \ldots \ldots \ldots$

Fig.4.10: Diagrama hierárquico do SGM ............... 57

Fig.4.11: Sistema de controle de transaçāo. ................ 58

Fig.4.12: Sistema multi-usuário MRO. ................... 60

Fig.5.1: Tipos de ligações entre a base original e a cópia .......... 64

Fig.5.2: Possíveis tipos de ligações entre a base cópia e original $\ldots \ldots \ldots \ldots 65$

Fig.5.3: Sub-operações da separação, manipulação e integração. ........ 67

Fig.5.4a: Níveis de granularidade no MRO. ................ 68

Fig.5.4b: Granularidade variável. ....................... 68

Fig.5.5: Descrição do registro de autorizaçāo para cada colônia. . . . . . . . 69

Fig.5.6: Contexto da colônia com os respectivos níveis de autorização. . . . . 70

Fig.5.7: Tipos de ligaçōes entre original e cópia $\ldots \ldots \ldots \ldots \ldots \ldots \ldots \quad 72$

Fig.5.8: Registros para Operação Distribuição. .............. 73

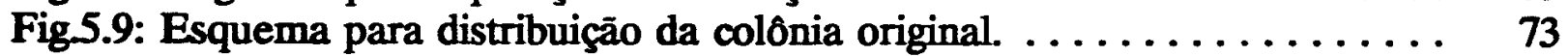

Fig.5.10: Esquema para distribuição da colônia cópia. ............ 74

Fig.5.11: Possf́veis tipos de ligaçōes para a operaçāo separação. $\ldots \ldots \ldots \ldots 76$

Fig.5.12: Tipos de acessos para os relacionamentos de interface. . . . . . . 83

Fig.5.13: Operação Integração para cada tipo de ligação. . . . . . . . . 88 


\section{LISTA DE PRIMITIVAS}

Primitiva 1: Geração_do_Registro_de_Autorização. ............. 77

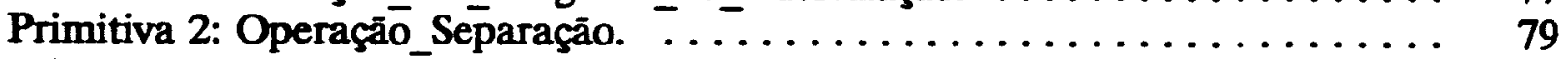

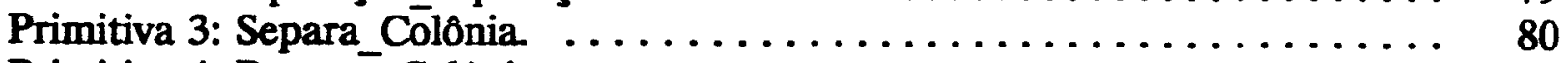

Primitiva 4: Preparā Colónia. ...................... 81

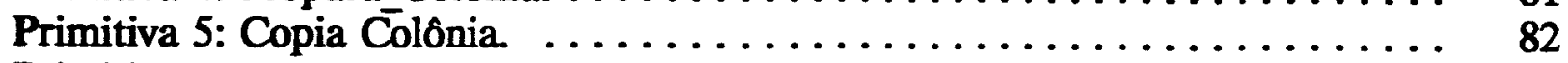

Primitiva 6: Tratamento_Relacionamento_Externo. ............. 84

Primitiva 7: Busca_Contexto. ................... 85

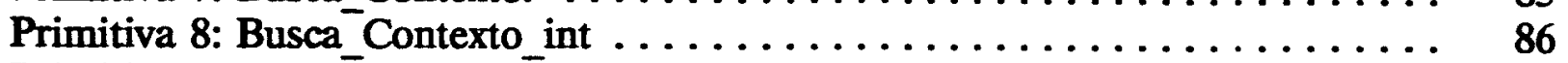

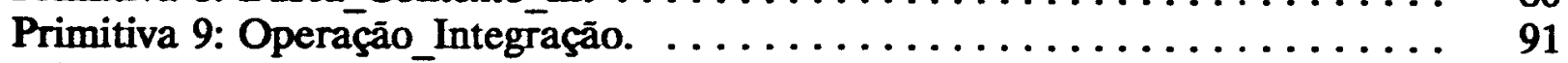

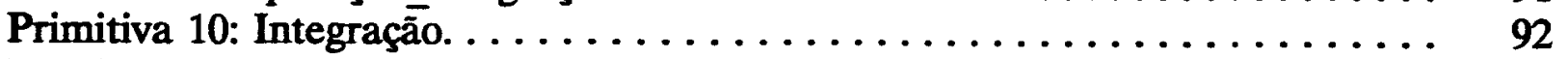

Primitiva 11: Intrg_Cria_Objeto. . . . . . . . $\ldots \ldots \ldots \ldots \ldots \ldots .93$

Primitiva 12: Intgr_Apaga_Objeto $\ldots \ldots \ldots \ldots \ldots \ldots \ldots \ldots \ldots \ldots \ldots .93$

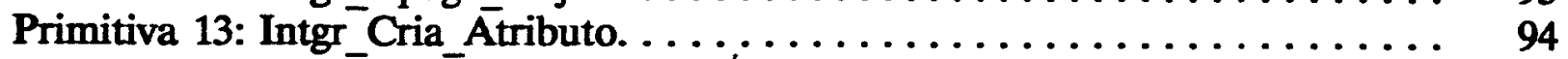

Primitiva 14: Intgr_Apaga_Atributo. . $\ldots \ldots \ldots \ldots \ldots \ldots \ldots \ldots \ldots .94$

Primitiva 15: Intgr_Modifica_Atributo. .................. 95

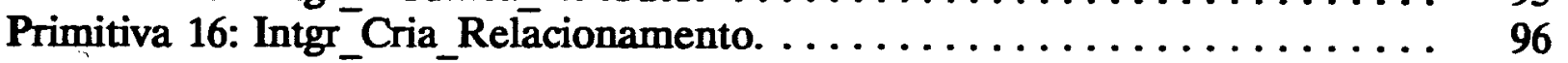

Primitiva 17: Intgr_Apaga_Relacionamento. ............... 96

Primitiva 18: Intgr_Modifica_Relacionamento. ................ 97

Primitiva 19: Intgr_Copia Atributo. ...................... 98

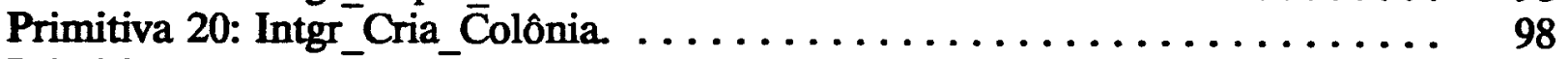

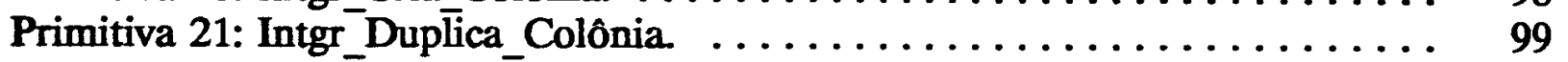

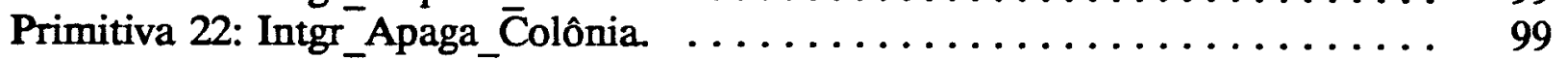

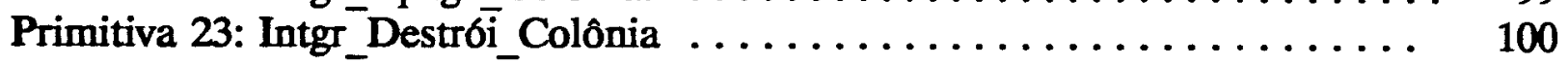




\section{RESUMO}

A distribuição de uma Base de Dados convencional caracteriza-se pela necessidade dos dados estarem disponíveis, ao mesmo tempo, a todos os usuários, de modo que os problemas de conflito devido a concorrência para obtenção dos mesmos, tornam-se muito acentuados.

A Base de Dados apoiada no Modelo de Representação de Objetos(MRO), devido a suas características semânticas, oferece o suporte necessário para atendimento das necessidades de distribuição num ambiente de desenvolvimento de projetos.

Neste trabalho é feita uma proposta de um modelo lógico e funcional para a distribuição da Base de Dados apoiada no MRO. Esta distribuição se caracteriza pela disponibilidade dos dados de forma que cada ítem (objeto) da base cópia possua um tipo de ligação com a base original. Foram definidos cinco tipos de ligações: apenas leitura (r-), isolado(is), flagrante(n), mutuamente exclusivo(me) e independente(in).

Com isto, tanto a base cópia como a original, respeitando as limitações impostas pelo tipo de ligação entre as mesmas, podem evoluir, e depois de um determinado tempo sofrerem um processo de integraçāo, que também é caracterizado pelo tipo de ligaçāo entre a base original e cópia. 


\section{ABSTRACT}

One of the most important characteristics of Distributed Database Systems is the permanent availability of data to all users at the same time. This situation emphatizes the conflicts occurring due to the competition among the users to obtain data.

Due to its semantics characteristics, the Database Systems based on the Object Representation Model (MRO) offer the necessary support to attend all the distribution needs in a computer-aided project development environment.

In this work, it is presented a functional and logical model for the distribution of MRO based databases. This distribution is charaterized by the availability of data. So far, each item (object) in each copied database has a kind of link with the original database.

Five types of links were defined: read only(r-), isolated(is), snapshot(n), mutually exclusive(me) and independent(in).

This arrangement allows both, the copied database and the original one, to evolve in parallel, restricted by the limits imposed by the kinds of links between them. After a while, the copied and the original databases may suffer an integration process, which is also characterized by these kinds of links between them. 


\section{Capítulo 1 \\ INTRODUÇĀo}

\section{1 - Caracterização do Problema.}

A distribuição de Bases de Dados Convencionais [CASANOVA_84], [BERNSTEIN_80a], caracteriza-se pela necessidade dos dados estarem disponíveis ao mesmo tempo a todos os usuários, de modo que os problemas de conflito devido à concorrência para obtençāo dos mesmos tornam-se muito acentuados.

Conseqüentemente, o desenvolvimento de um sistema que trate tal distribuição é especificado de modo a não permitir inconsistência dos dados. Para isso, existem algoritmos que buscam escalonamento de transações conflitantes [ESWARAM_76], que operam sobre um conjunto de dados parcialmente ou totalmente comuns a mais de um usuário.

Esses algoritmos atendem tanto uma situação de concorrência dos dados num ambìente multi-usuário, como também num ambiente distribuído. Ressalta-se, no entanto, que as características de cada uma dessas situações são diferenciadas, devido à natureza das transaçōes envolvidas. Num ambiente multi-usuário, o tempo da transação é normalmente pequeno, configurando assim um sistema de controle de concorrência que atenda à especificação em questão.

Além do problema de concorrência num Sistema de Bases de Dados Convencionais, existe também o Controle de Integridade [CASANOVA_84], que é ainda mais acentuado num ambiente distribuído, em decorrência da possibilidade de falhas, durante a comunicação entre os nós pertencentes à rede. Em decorrência disso, são usadas Estruturas Robustas, de modo a diminuir o efeito das falhas de comunicação no sistema Embora isto comprometa ainda mais a eficiência do Sistema, oferece ao usuário a existência "simultânea" e consistente dos dados.

Este trabalho preocupa-se com a caracterização de algoritmos que atendam às necessidades de distribuiçâo de ambientes automatizados para suporte a projetos. As necessidades de distribuição num ambiente para desenvolvimento de projetos são 
distintas daquelas impostas pelas aplicaçōes convencionais.

Uma característica muito importante num ambiente computadorizado de suporte ao desenvolvimento de projetos é o fato de tanto a cópia quanto a versão original poderem evoluir independentemente, ou então apenas uma evoluir mas manter liberadas as operaçōes de leitura nas demais cópias. Após um determinado tempo, as bases cópia e original podem sofrer um processo de re-integração, o qual sintetiza as operaçôes ocorridas tanto na cópia quanto na original.

Com isto algumas características importantes em aplicaçōes convencionais, tal como a atomicidade e serializabilidade passam a não ter a mesma relevância na especificaçāo de um ambiente distribuído voltado a desenvolvimento de projetos, enquanto outras necessidades tornam-se mais importantes de serem atendidas pelo sistema distribuido.

Em funçāo das novas necessidades de distribuiçāo, buscou-se estudar um modelo de representaçāo de dados, mais especificamente o Modelo de Representação de Objetos-MRO [TRAINA_88], que apresenta características que atendem a um amplo espectro de aplicaçōes, incluindo aplicaçōes integradas de projeto e produção de sistemas em geral.

Tal como seu nome indica, o Modelo de Representação de Objetos possui o enfoque de ser orientado a objetos, devido ao fato de permitir a representação de informações tanto através de conjuntos de objetos estruturalmente semelhantes, quanto individualmente, permitindo tratar de cada objeto isoladamente, quando for o caso. Devido a isso, é um modelo que permite a representação de grande conteúdo semântico, adequado a sistemas de apoio à documentação e desenvolvimento de projetos, onde cada objeto de projeto tanto pode ser único, quanto podem existir conjuntos de dados semelhantes, tratados coletivamente. Além disso, o MRO permite a construção de MetaSistemas, em que a especificação dos requisitos da própria aplicação deve ser mantida na Base de Dados.

Neste trabalho buscou-se tornar um problema complexo que é a distribuição de um modelo que tem uma grande representação semântica, em aspectos mais simples que pudessem ser abordados em detalhes. Para isso, a operação de distribuição foi desmembrada em diversos processos bem localizados. Primeiramente dividiu-se em três processos mais genéricos: separaçāo, manipulaçāo e integração. Posteriormente cada um destes processos foi tratado de modo específico. Com isso, o problema inicial de distribuição de uma base de dados voltada ao suporte de ambientes de projeto foi 
dividido em um conjunto de problemas bem menores, e foi empreendida sua análise.

\section{2 - Organização do Trabalho.}

- Capítulo 1: Apresentam-se as idéias básicas que motivaram o desenvolvimento deste trabalho ora apresentado, bem como a sua organização.

- Capítulo 2: São apresentados conceitos relevantes para o Controle de Concorrência em Bases de Dados Convencionais: Teoria da Serializaçāo, Escalonadores Baseados em Bloqueios e em Pré-ordenação.

- Capítulo 3: E feita uma apresentação dos tipos de falhas que podem ocorrer num Sistema de Base de Dados. São também abordados os mecanismos que objetivam diminuir o efeito de tais falhas: Programas Restauradores, Descargas, Arquivos Diferenciais, Atas e Imagens Transientes. Finalmente, é apresentado o Protocolo de Bloqueio Bifásico para Comunicaçōes.

- Capítulo 4: E feita uma apresentação detalhada dos conceitos do MRO: Objetos, Relacionamentos, Atributos, Colônias. Eapresentado também um exemplo de modelagem utilizando o experimento de resfriamento de átomos. São tratados também aspectos do Gerenciador de Objetos em suas versōes mono-usuário e multi-usuário.

- Capítulo 5: Apresenta um Projeto Funcional e Lógico para a Distribuição do MRO, juntamente com as primitivas especificadas para as Operações de Separação e Integração. E neste capítulo que apresentam-se as contribuições para o Modelo de Representaçāo de Objetos, as quais não foram previamente estabelecidas em outros trabalhos.

- Capítulo 6: É apresentada uma análise dos resultados deste trabalho, através da descrição das principais decisōes de projeto adotadas, as sugestōes de novas pesquisas e conclusões. Isto é feito principalmente em referência ao projeto apresentado no capítulo 5. 


\section{Capítulo 2 \\ CONTROLE DE CONCORRÊNCIA}

\section{1 - Descrição do Problema.}

O desenvolvimento de bases de dados distribuídas surgiu da necessidade de se compartilhar os mesmos dados usados em locais distintos. Portanto, pressupōe-se a existência de um conjunto de unidades computacionais interligadas (nós), cada uma contendo um Sistema Gerenciador de Base de Dados, idênticas ou não, capazes de processar as transações locais (operaçōes sobre o banco de dados local) e as transaçōes globais que solicitam o acesso a dados em outros nós.

Por distribuição de dados entende-se: a replicação de duas ou mais cópias do mesmo arquivo alocadas em nós distintos; ou o particionamento de arquivos divididos em conjuntos disjuntos e alocados em nós específicos, sem duplicação da base de dados.

Existem diversas maneiras para conectar os nós, e o critério para a adoçāo de determinada configuração dependerá fundamentalmente da maneira com que se deseja distribuir os dados. A figura 2.1 apresenta formas básicas de conexão dos nós: estrela, anel e árvore.

A especificação de sistemas de base de dados tem se apoiado tradicionalmente na arquitetura centralizada. Nessa situaçāo existe um único computador onde processam-se todas as transações solicitadas pelos vários usuários. Tal arquitetura tem se mostrado eficiente para solucionar problemas de controle de segurança, integridade, e de modo geral, o gerenciamento das operaçōes sobre os dados.

Entretanto a arquitetura centralizada não facilita a disponibilidade de dados ao usuário. Esse problema tende a se agravar quando um grande número de transações de 
diversos usuários solicita operaçōes sobre a base de dados centralizada. Outro fator importante é que o custo de processamento da comunicação tem aumentado em relação ao custo dos processadores. Com isto, ao invés de transportarem-se os dados para um processador central, aloca-se a capacidade computacional para o nó que dispõe dos dados para a manipulaçāo local.

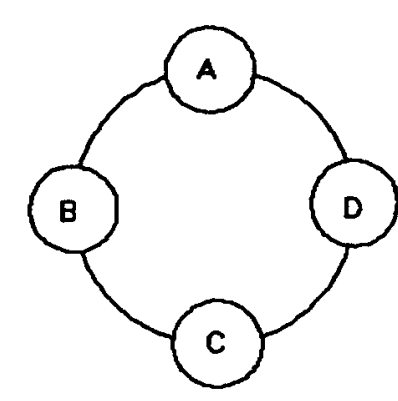

Rede Anel

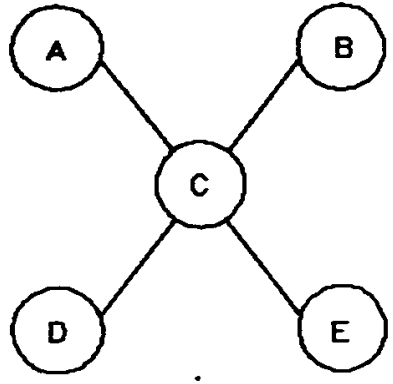

Rede Estrela

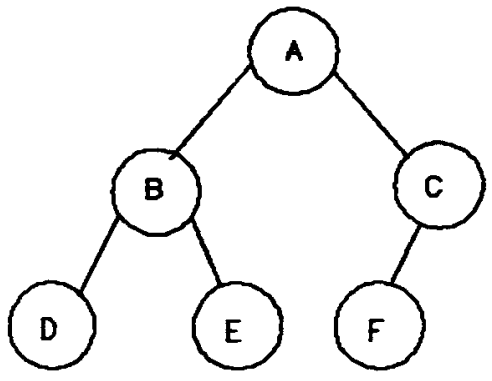

Rede Árvore

Fig21: Formas de conectar os nos

Aliado a estas vantagens, uma base de dados distribuída pode ser projetada de modo a melhorar a disponibilidade de dados em cada local, através da replicação ou particionamento em cada nó, dos dados pertencentes ao sistema, permitindo assim o crescimento modular, através da adiçāo de novos processadores e conseqüentemente novos blocos replicados ou particionados.

A arquitetura de um sistema distribuído traz muitas dificuldades para o desenvolvimento de um Sistema Gerenciador de Bancos de Dados Distribuídos (SGBDD) genérico.

Para um controle de concorrência consistente, é necessário o conhecimento do estado global do sistema [BERNSTEIN_80a], ou seja, é preciso conhecer nāo só a maneira da distribuiçāo dos dados, mas também ter o controle e a informação sobre a situação geral do sistema. Portanto um SGBDD não pode ser entendido apenas como uma soma de Sistemas Gerenciadores de Base de Dados centralizados. Existe a necessidade de uma camada de software [BERNSTEIN 80b] que interligue os SGBD locais, possibilitando a implementação da Arquitetura Distribuída, que a nível do usuário pode ser vista como consistindo dos seguintes elementos:

-Transaçōes; comunicam-se com os Gerenciadores de Transaçōes. 
-Gerenciadores de Transações (GT); supervisionam as transações submetidas, enviando-as para os devidos nós para execuçāo.

-Gerenciadores de Dados (GD); operam sobre a base de dados de acordo com as especificações dos GT.

A figura 2.2 ilustra os conceitos descritos apresentado interaçōes entre os mesmos.

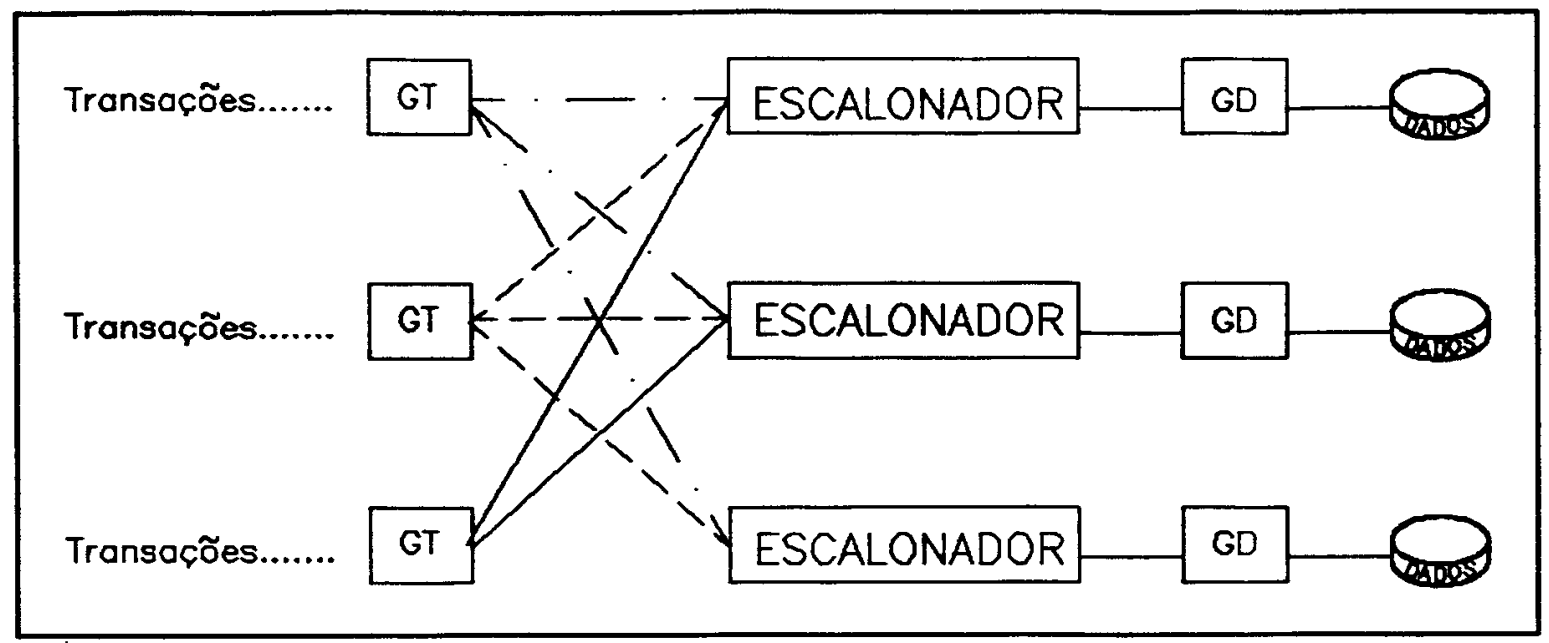

Fig.22: Arquitetura de um SGBDDD.

As solicitaçōes de operaçōes sobre a base de dados são feitas através de transaçōes, as quais são conjuntos de comandos em uma linguagem de manipulação de dados. Os comandos são decodificados e executados pelo sistema gerenciador de base de dados. Tal conjunto deve ser iniciado e finalizado respectivamente pelos comandos COMEÇO-DE-TRANSAÇÃOe FIM-DE-TRANSAÇÃO. Cada transaçāo T corresponde a uma sequeência de ações elementares sobre os objetos da base de dados. As transações devem ser codificadas de maneira que sempre sejam concluídas e ainda preservem a consistência da base de dados.

Dentre os problemas citados, o controle de concorrência tem merecido grande atençāo na procura de soluçōes. Quando se têm transaçōes que comutam, ou seja, o resultado final das transaçōes independe da ordem pela qual são executadas, então dizemos que tais transaçōes não sāo conflitantes. Entretanto, parte das transaçōes em um ambiente distribuído não comutam. Com isto tem-se duas possibilidades:

-ou submetem-se as transaçōes para execuçāo em modo seqūencial, tendo-se um critério pré-estabelecido, como por exemplo data e local da transação; -ou procura-se estabelecer um escalonamento único, composto de operaçōes que fazem parte de cada transação, equivalendo a execução seqüencial das transações envolvidas.

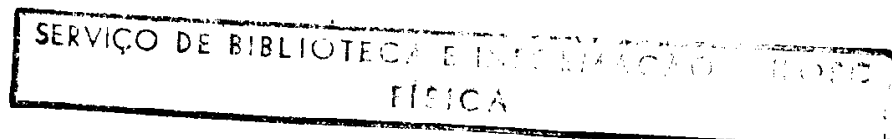


Casanova em [CASANOVA_84], afirma que a Teoria da Serialização se propõe a capturar de forma precisa quando, numa execução concorrente de um grupo de transações, cada uma delas é executada integralmente sem interferência.

\section{2 - Teoria da Serialização.}

\subsection{1 - Execução Serial.}

Pode-se afirmar que o objetivo do gerenciamento da execuçāo serial de transaçōes concorrentes [CASANOVA_84] é garantir a equivalência computacional.

Formulando mais precisamente este conceito, garante-se que uma execução E de um conjunto de transaçōes $T$ gerada por um escalonamento global $L$ é serial se e somente se:

-para cada escalonamento local de L, para cada par de transações Ti e Tj em T, ou todas as operações de Ti precedem todos as operaçōes de $\mathrm{Tj}$, ou vice-versa; -para cada par de transaçōes Ti e Tj, se as operações de Ti precedem as operaçōes de Tj em um escalonamento local de L, então o mesmo é verdade para todos os outros escalonamentos de $\mathrm{L}$.

\subsection{2 - Equivalência de Execuçóes.}

Além da Execução Serial, outro conceito importante é a Equivalência de Execuções [DATE_88]. Esse conceito estabelece que as execuçōes E1 e E2 que inicializam com um mesmo estado de dados são equivalentes, quando:

-E1 e E2 geram estados finais idênticos

-em qualquer momento da transação T os dados lidos por E1 e E2 sāo os mesmos.

\subsection{3 - Execuçōes Serializáveis.}

Para que uma execuçāo $\mathbf{E}$ de um conjunto $T$ gerado por escalonamento $L$ seja serializável, necessariamente $\mathrm{E}$ tem que ser equivalente a uma Execuçāo Serial. 
Com os conceitos de Execução Serial e Equivalência de Execuçōes, conclui-se que um método de controle de concorrência incluirá apenas transações que permitam Execuções Serializáveis. Isso equivale a dizer que, se execuçōes sāo serializáveis, é porque são equivalentes a execuções seriais, e como as execuçōes seriais garantem naturalmente a consistência dos dados, conseqũentemente as execuçōes serializáveis herdarão tal propriedade.

Para encerrar as considerações sobre a teoria da serialização apresenta-se, através de dois teoremas, condiçōes suficientes embora não necessárias, que garantem que diante de um conjunto de transações T1 ..... Tn ocorrerá a serialização.

\subsection{4 - Teorema da Serialização.}

Há duas maneiras de definir o Teorema da Serialização [CASANOVA_84] [BERNSTEIN_81]:

-a primeira, é através da utilização de grafos. Considerando-se um escalonamento L sobre um conjunto de transaçōes $T 0, T 1, T 2, \ldots . T n$, o grafo de serializaçāo para $L$, GS(L) teria as transaçōes T0, T1,...,Tn como vértices do grafo sendo suas arestas tal que, para algum objeto $x$, exista:

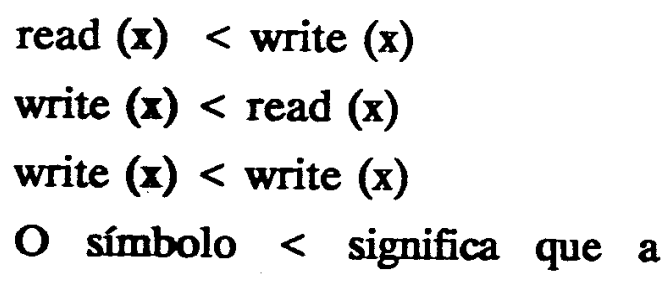
operação da esquerda precede 'a operação da direita.

Um possível GS(L) é apresentado através da figura 2.3 , onde descreve-se a dependência das transações.

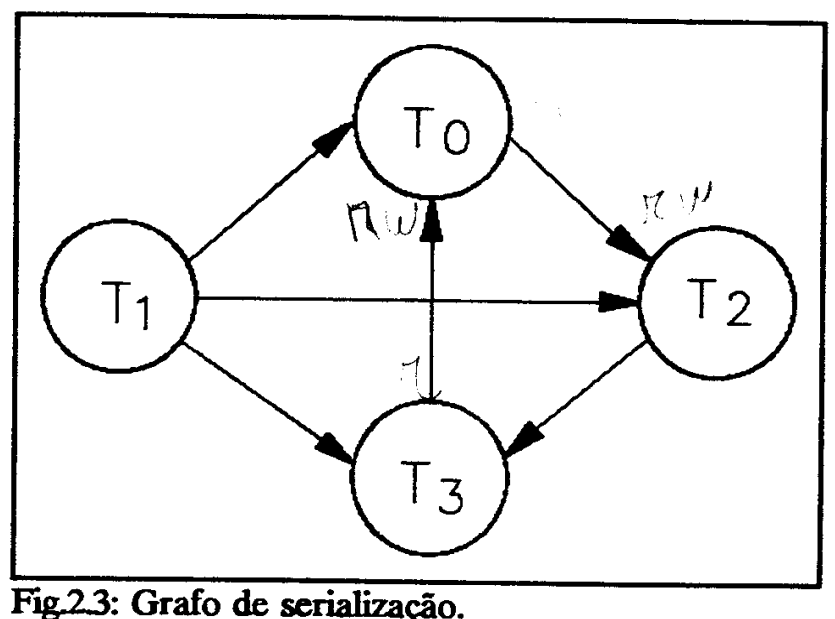

Teorema1: Se GL(L) é acíclico então L e Serializável.

-a segunda, utilizando considerações formais. Seja $T$ um conjunto de transaçōes e $L$ um escalonamento global para $T$. Seja $L_{\mathbf{k}}$ um escalonamento local de $L$. Duas ações elementares $O_{i}$ e $O_{j}$ de $L_{k}$ conflitam se e somente se elas agem sobre um mesmo objeto físico e uma delas é uma operação de atualização. Operações conflitantes são 
importantes pois, se sua ordem relativa for alterada em $L_{\mathbf{b}}$ o resultado final da execução poderá ser modificado. Tome-se como exemplo as operaçoos read(x) e write(x). Supondo-se que $\mathbf{L}_{\mathbf{x}}$ seja da forma ...read(x)....write(x)....,então read(x) não lê o valor de $x$ que foi criado por write(x). Se a ordem das operações for trocada em $\mathbf{L}_{\mathbf{k}}$ para ..write(x)...read(x)... e entre write(x) e $\operatorname{read}(x)$ nāo houver uma outra operação de atualizaçāo para $x, \operatorname{read}(x)$ passará agora a ler o valor criado por write(x), possivelmente (mas não necessariamente) alterando o estado final do banco de dados ou das operaçōes resultantes. Definiremos ainda que $O_{i}$ precede com conflito $O_{j}$ em $L_{k}$ (denotado por $O_{i}<O_{j}$ ) se e somente se $O_{i}$ ocorre antes de $O_{j}$ em $L_{k}$ e $O_{i}$ e $O_{j}$ conflitam.

De posse desta relação entre açōes elementares, define-se que $T_{i}$ precede por conflito $T_{\mathbf{j}}$ em $L$ (denotado por $T_{\mathbf{i}}<T_{\mathbf{j}}$ ) se e somente se existir um escalonamento local $L_{k}$ de $L$ e operaçōes $O_{i}$ e $O_{j}$ em $L_{k}$ tais que $O_{i}$ e $O_{j}$ são operaçōes de $T_{i}$ e $T_{j}$ respectivamente e $\mathrm{O}_{\mathrm{i}}<\mathrm{O}_{\mathrm{j}}$. A relaçāo < é chamada de relação de precedência por conflito para $T$ induzida por $\mathbf{L}$ Novamente quando mais de uma destas relações estiverem em jogo, subscritos serão usados para distinguí-las.

Teorema2: Seja $\mathrm{T}=(\mathrm{T} 1, . . ., \mathrm{Tm})$ um conjunto de transaçōes e $\mathrm{E}$ uma execução de $T$ modelada por um escalonamento global $L=(L 1, . ., L n)$. Se a relação de precedência por conflito para $T$ induzida por $L$ for uma relação de ordem parcial, então $E$ é serializável.

\section{3 - Escalonadores Baseados em Bloqueios.}

Estratégias de bloqueio ou exclusão mútua, consistem em algoritmos e procedimentos que visam evitar a geração de escalonamentos incorretos, através do atraso de uma ou mais transaçōes que tentam executar operaçōes que causam conflito no acesso ao mesmo objeto [ESWARAN_76].

O objetivo dos algoritmos de bloqueio é permitir a ocorrência de execuções simultâneas apenas de operaçōes não conflitantes, e serializar as operações conflitantes de modo a garantir a consistência dos objetos.

Geralmente pode-se detectar o conflito das operaçōes através de uma matriz de ordem $\mathrm{n} x \mathrm{n}$, onde cada linha ou coluna representa uma determinada operação. Como 
exemplo, seja:

$\mathrm{Mij}=1 \Rightarrow$ modos compativeis

Mij $=0 \Rightarrow$ não compatíveis

onde:

M11 = 1 operação ler-ler

M12 = 0 operação ler-gravar

M21 = 0 operação gravar-ler

M22 = 0 operação gravar-gravar

Dessa maneira, o escalonador permitiria apenas a execução simultânea da operação M11.

No contexto de serializadores baseados em bloqueios, existem duas situações para os objetos:

-Bloqueado: apenas a transação que obtém o objeto pode acessá-lo;

-Livre: qualquer transação pode requisitar o objeto.

Além das funçōes Ler(x) e Gravar(x) tem-se:

-Bloq(x): bloqueia o objeto x para uma determinada transação;

$-\mathrm{Lib}(\mathrm{x})$ : libera 0 objeto $\mathrm{x}$ para próximas transaçōes.

Estas funções são controladas pelo gerente de bloqueio, o qual deve manter as informaçōes sobre cada objeto bloqueado, qual transação o bloqueou, e as transações seguintes que solicitam o objeto. Como exemplo, poderia ser utilizada uma tabela com a tripla $(\mathrm{x}, \mathrm{T}, \mathrm{F})$, onde:

$x$ : identificação do objeto $x$

$T$ : transação que bloqueia $x$

F: fila de espera das transaçōes que solicitam o objeto $x$.

Para se ter uma noção mais concreta da situação de um objeto no que se refere ao seu estado de bloqueio e liberação, tem-se abaixo as idéias fundamentais para uma 
possível implementação do Gerente de Bloqueio:

Operaçóes do Gerente de Bloqueio

OP1: -Inicializar a tabela de objetos bloqueados(zerar).

OP2. -Pesquisar a tripla com o objeto x que foi solicitado pela transação $T$ através da funçāo $\operatorname{Bloq}(x)$ :

-Se encontrou, acrescente $T$ no final da Fila $F$ da tripla em questão;

- Senão, acrescente a tripla $(x, T, F)$ na tabela.

OP3: •Pesquisar a tripla com objeto $x$ liberada pela transação $T$ através da função

$\operatorname{Lib}(x)$.

-Se encontrou:

- Se F vazia, retire a tripla da tabela para liberação de $x$;

- Se $F$ näo vazia retire $T$ da fila e libere $x$ para $T$,substituindo a tripla $(x, T, F)$ por $\left(x^{\prime}, T^{\prime}, F^{\prime}\right)$.

-Senão:

-Ignore a função $\operatorname{Lib}(x)$.

\subsection{1 - Bloqueios Mátuos (DeadLock).}

O método de bloqueios [KORTH_82], [KORTH_83], em alguns casos poderá impedir o término das transaçōes. Isto acontece quando as esperas não sāo controladas.

Suponha a seqüência de transaçāo T1, T2 e T3 ilustrada com a figura 2.4 onde cada uma representa a leitura ou gravação de um determinado objeto.

G1(y) não escalonado pois conflita com L2(y)

G2(z) não escalonado pois conflita com $\mathbf{L 3}(z)$

G3(x) nāo escalonado pois conflita com L1(x)

A probabilidade de bloqueios mútuos pode ser aumentada se: 


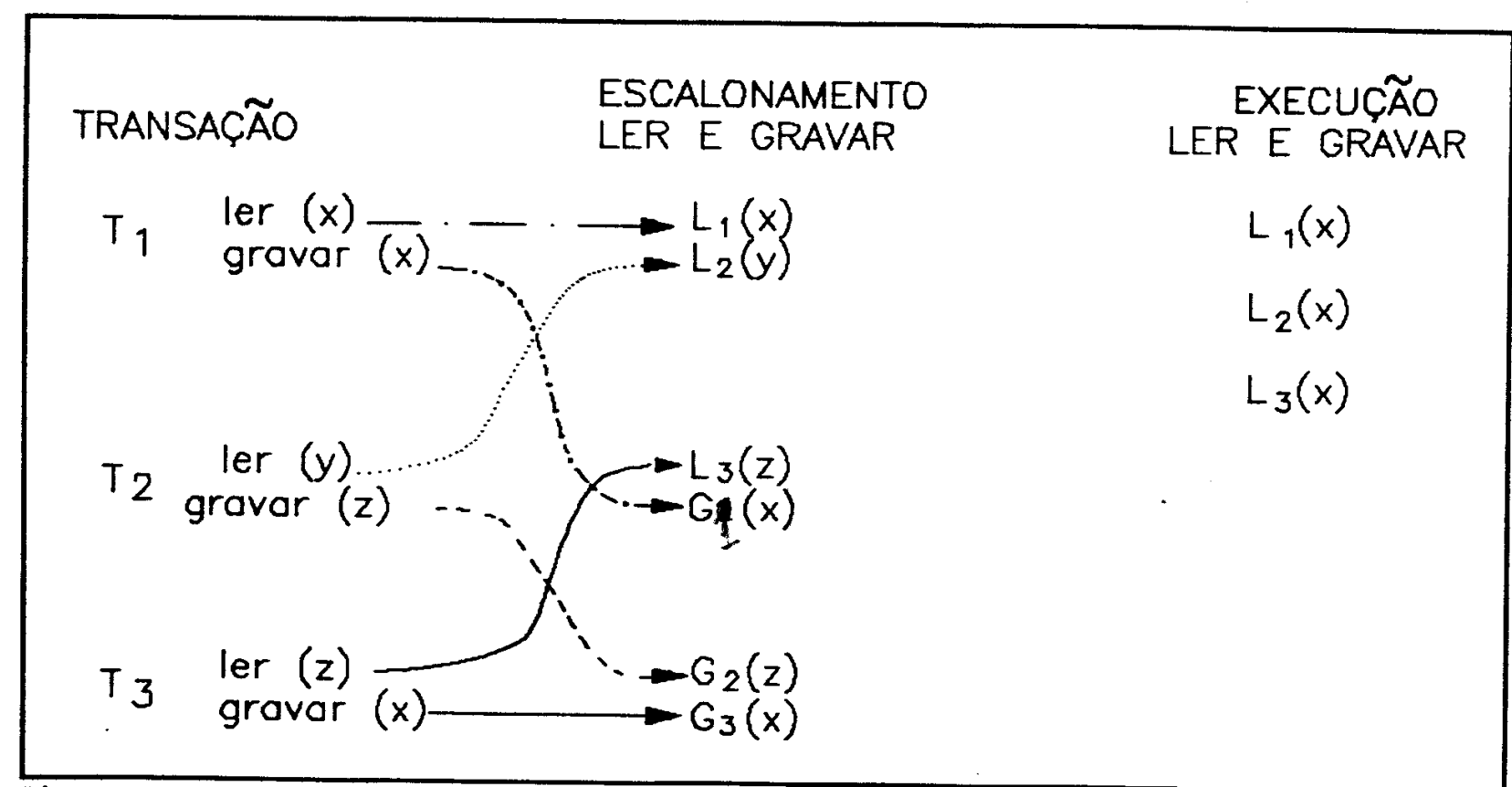

Fig_24: Sequência de transaçōes T1,T2 e T3.

-mais de uma transação é bloqueada esperando por um mesmo objeto.

-a execução de uma transaçāo não pertencente a um determinado conjunto de transaçōes, não permite a liberação de qualquer transação pertencente a esse conjunto.

Há duas maneiras para evitar o bloqueio mútuo:

-Deteção/Solução: periodicamente um processo independente I é disparado para detectar e solucionar bloqueios mútuos. Isto pode ser feito mantendo-se dígrafos de "deadlocks". Os vértices do dígrafo representam as transaçōes, e as arestas representam o relacionamento "esperando por". Se uma aresta é definida da transação Ti para Tj e se Ti está esperando por um bloqueio retido por Tj, configura-se então um bloqueio mútuo. Portanto a fase de deteç̧ão limita-se a verificar se o dígrafo é acíclico ou não. A figura 2.5 ilustra tal situaçāo.

A fase de soluçāo consiste em retirar transaçōes, de forma que o dígrafo torne-se acíclico. Existem vários critérios para escolher a transação a ser retirada do dígrafo: uma possibilidade consiste na eliminação do arco correspondente a transação mais recente de um ciclo do sistema.

-Prevenção: um método satisfatório para previnir o bloqueio mútuo considera que 
deva ser realizado um teste para cada transação Ti que solicita um novo objeto ocasionalmente já bloqueado por $\mathrm{Tj}$. Se Ti passar pelo teste, então a transação pode ser acrescentada na fila da tripla de $x$, caso contrário cancela-se $\mathrm{Ti}$ ou $\mathrm{Tj}$. Quando o critério adotado para escolha da transação cancelada for Ti entāo o

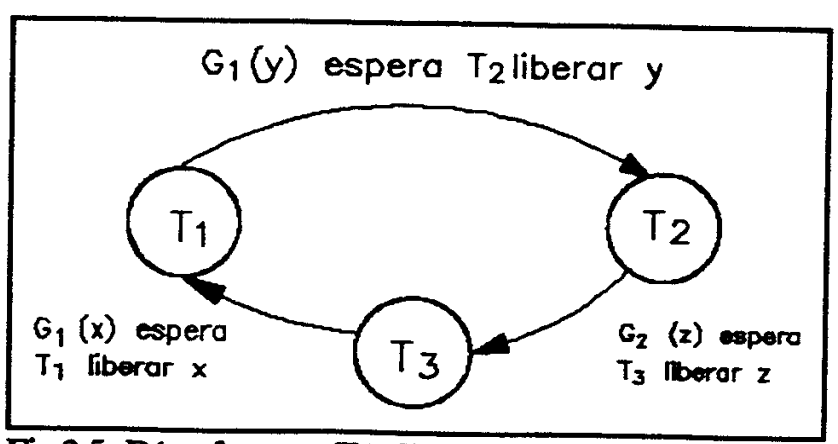

Fig.25: Digrafo para T1, T2 e T3.

método é chamado de não preemptivo, se for $\mathbf{T j}$, o método é preemptivo.

O objetivo da prevenção é garantir que ao inserir-se Ti na fila da tripla(x,T,F) da tabela de espera de transaçōes, nunca ocorra a formação de bloqueios mútuos. Isso corresponde ao fato de que no dígrafo de espera, cada nova inserçāo não cria ciclos.

\subsection{2 - Método de Bloqueio em Duas Fases (2PL).}

Como qualquer método baseado em bloqueio,o 2PL [BERNSTEIN_81] deve garantir que todas as transaçōes iniciadas em um escalonamento E sejam concluídas (como já discutiu-se anteriormente) e ainda que E seja serializável.

Apenas o uso de bloqueios não garante a serialização. Por exemplo:

-bloquear $\mathrm{x}$ antes de acessá-lo

-liberar $\mathrm{x}$ imediatamente após acessá-lo

Considerando esses dois critérios obter-se-ia qualquer intercalação entre as operações das transações e nāo necessariamente uma serializaçāo.

Para garantir a serialização é necessário que existam duas fases:

-a transação deve bloquear cada objeto antes de acessá-lo e liberar todos os objetos bloqueados antes de sua finalização.

-a transação não pode bloquear novos objetos depois da liberação de algum objeto anteriormente bloqueado.

Pode-se ilustrar estas fases através de um gráfico apresentado na figura 2.6. 


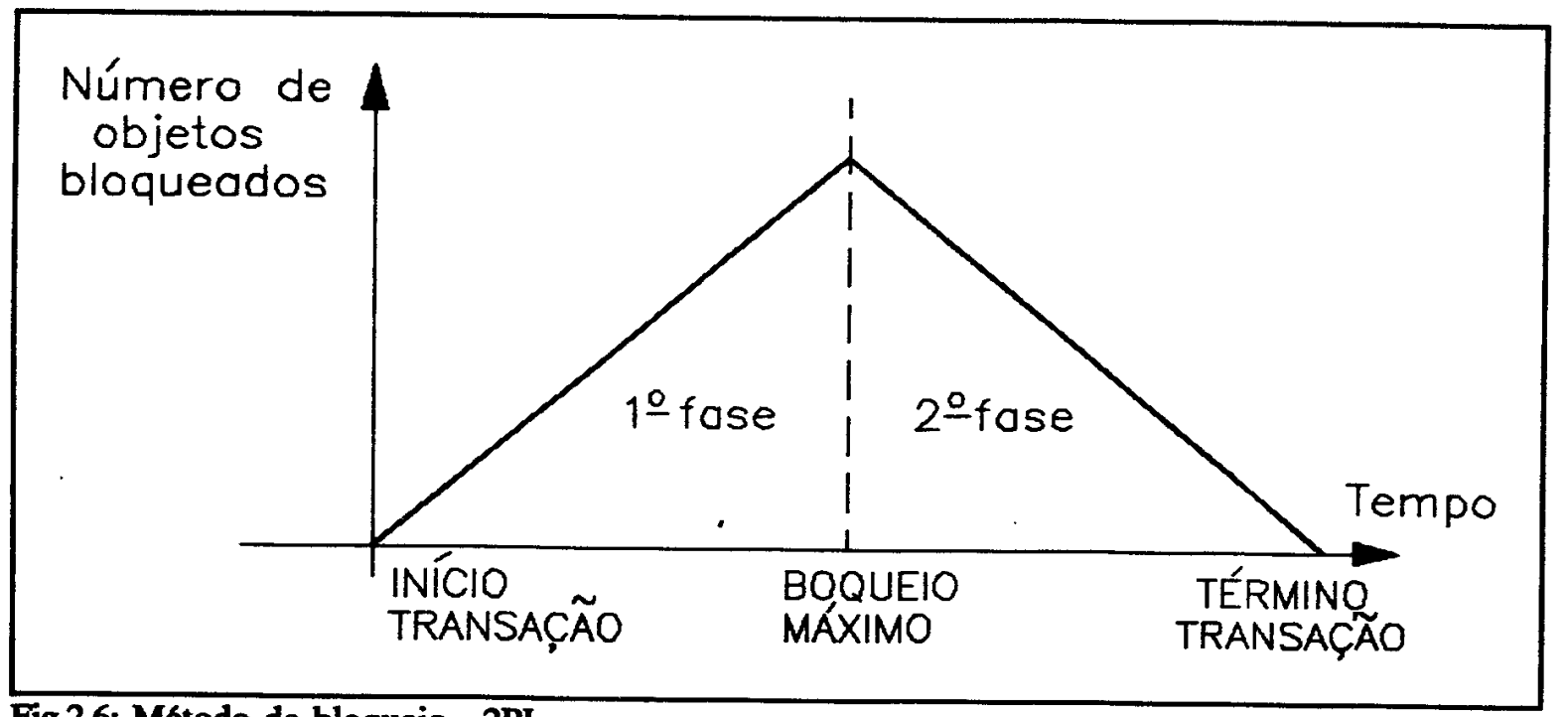

Fig.2.6: Metodo de bloqueio - 2PL.

A ordem da serialização é obtida em função da seqüência pela qual as transações solicitam e obtêm os bloqueios sobre os objetos que serão então bloqueados até o fim da primeira fase. Após o bloqueio máximo, os objetos começam a ser liberados até atingir o término da transação.

\subsection{3 - Métodos de Bloqueio num Ambiente Distribuído.}

Num ambiente distribuído, apresenta-se um problema adicional que é a localização da tabela de bloqueios ao longo da rede, dificultando a deteção de bloqueios mútuos globais [DATE_88].

Existem três variaçōes do método para o ambiente distribuído:

-Básica; considera que a tabela de bloqueios é distribuída para cada nó, juntamente com os dados. Esta variação caracteriza-se pela dificuldade de deteção dos bloqueios mútuos. Uma possível implementação deveria conter os seguintes aspectos:

a)para cada operação sobre o objeto x, realizada em um determinado n6, um bloqueio $\operatorname{Bloq}(x)$ deve ser criado imediatamente antes.

b)imediatamente após a mensagem de "Prepare-se" recebida pelo nó remoto para a atualizaçāo de um determinado objeto $\mathrm{x}$, na primeira fase do bloqueio 2PL, deve ser criado um bloqueio $\operatorname{Bloq}(\mathrm{x})$. 
c)imediatamente após a mensagem de "Prepare-se" recebida pelo nó remoto, na primeira fase do bloqueio 2PL, se o objeto $x$ não foi alterado, uma liberação Lib(x) deve ser criada.

d)após receber a mensagem "Confirme", ou seja, as modificaçōes já estão instaladas no banco de dados, ou após uma mensagem "Cancele", uma liberação $\mathrm{Lib}(\mathrm{x})$ deve ser criada.

Este método não pressupõe um controle de cópias. Se os objetos bloqueados se constituem em cópias, o gerente de transações é que deverá solicitar as respectivas atualizaçōes, ficando desse modo transparente ao controle de concorrência.

-Implementação por Cópias Prímárias; na tentativa de diminuir o desperdício dos recursos locais pelo bloqueio realizado em todas as cópias de um mesmo objeto logico, pode ser utilizado o recurso de manter-se cópias primárias. Este recurso consiste num conjunto de objetos físicos segmentados, onde cada segmento contém cópias do mesmo dado, sendo que um único objeto físico é o representante do referido segmento denominado de cópia primária(xp). Antes de qualquer operação sobre algum objeto pertencente ao segmento, a cópia primária correspondente deverá ser bloqueada. A nível de implementação, os mesmos aspectos da variação Básica devem ser seguidos, com o incremento de mensagens para que, a cada transação $T$ que solicita um objeto $\mathrm{x}$, envie-se para o nó que detém a cópia primária um bloqueio de xp para $T$. Caso obtenha sucesso no bloqueio, o nó detentor de xp, envia a resposta confirmando o bloqueio.

Embora exista uma tendência a diminuir o processamento local de cada nó em função da diminuição do número de bloqueios, a cópia primária exigirá mensagens adicionais gerando um aumento do tráfego na rede.

Este problema pode ser contornado variando a granularidade na formação de cada objeto lógico, ou seja, reagrupar objetos físicos em unidades lógicas que representarāo um grupo, e por sua vez a respectiva cópia primária, diminuindo-se o número de mensagens enviadas. A granularidade tem um limite: nāo se pode atribuir a um objeto $x$ todo o banco de dados.

A deteçāo dos bloqueios mútuos é difícil de ser realizada devido a distribuição das cópias primárias pelos diversos nós. 
-Implementaçảo por Bloqueio Centralizado; as duas propostas anteriores dificultam a deteção de bloqueios mútuos pois necessitam consultar todos os nós.

Uma outra solução consiste em centralizar a tabela de bloqueios em um nó coordenador da rede. Para cada objeto a ser acessado é necessário consultar o referido nó para obter resposta sobre o estado do objeto requisitado.

Dessa maneira, a deteção de bloqueios mútuos é imediata, bastando consultar o nó coordenador.

Entretanto tal proposta gera uma dependência muito grande da base de dados em relação ao nó coordenador, acarretando dois problemas: sobrecarrega uma região localizada da rede com mensagens adicionais; cancelamento de todas as transações, quando o nó coordenador em questão não puder ser contactado, exigindo assim que um outro nó seja eleito para coordenador.

\subsection{4 - Bloqueios Mátuos no Caso Distribuído.}

No caso distribuído os problemas sāo semelhantes ao centralizado, adicionando porém, um outro elemento na geração de prioridades, pois transaçōes podem ter a mesma prioridade, mas submetidas em nós distintos. $O$ par $(n, t)$ soluciona o impasse, onde:

n: identificação do nó

t: data/hora em que a transação' foi gerada

A deteçāo/solução de bloqueios mútuos no caso da implementação básica e cópia primária é difícil de ser realizada, pois não se tem garantia que a união dos subgrafos acíclicos dos diversos nós, resulte um grafo geral acíclico.

Uma soluçāo consiste em considerar subgrafos de espera local e grafo de espera global. Periodicamente, cada nó envia seu subgrafo local a um determinado nó central que construirá o grafo global utilizando os mesmos critérios do caso centralizado. Esta solução caracteriza-se por resolver bloqueios de maneira mais localizada.

\section{4 - Escalonadores Baseados em Pré-ordenação.}


No controle de concorrência por Pré-ordenação [BERNSTEIN_80a], [BERNSTEIN_81], [CASANOVA_84], a ordem das operaçōes é estabelecida antes das transações serem submetidas. O protocolo básico, em linha geral, limita-se a a garantir duas condiçōes: a) cada transaçāo, antes de ser iniciada, deve receber uma "senha", exclusiva ao longo da rede, sem o conhecimento do usuário.

b) em cada nó deve haver um tratamento para as transaçōes conflitantes, tendo como critério a avaliação das senhas de cada transação.

O protocolo de Pré-Ordenação opera de maneira oposta ao de Bloqueio. $\mathrm{Na}$ situação de Pré-Ordenação a geração e atribuiçāo das senhas às transações impōe uma ordem antes das transaçōes serem submetidas. Já no caso de Bloqueio, as transaçōes são submetidas e a serialização ocorre quando as transações solicitam determinados objetos ou recursos. Isto impōe uma diferença fundamental entre as duas filosofias de controle de concorrência, oferecendo assim opçōes para implementação dos mecanismos de controle de concorrência de acordo com as exigências do ambiente em que se insere a distribuição dos dados. Haverá situaçōes em que as características das transaçōes determinarão qual mecanismo usar: bloqueio ou pré-ordenação.

\subsection{1 - Implementação Básica.}

Como foi dito anteriormente; o protocolo de pré-ordenaçāo tem duas características:

-geração das senhas;

-tratamento das senhas em cada nó para criação do escalonamento.

A solução do tratamento das senhas pode ser feita através da atribuição para cada objeto físico do sistema, das seguintes variáveis:

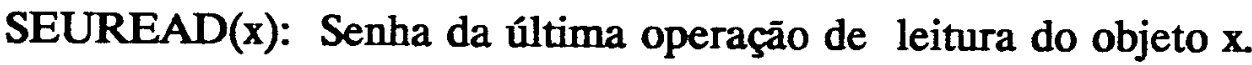

SEUWRITE(x): Senha da última operação de escrita do objeto $x$.

Com estas duas variáveis, um algoritmo possível para controle das senhas, teria que tratar as seguintes situações:

-Se for uma operação de leitura $\boldsymbol{R}(x)$ com número de senha= $\gamma$ então:

- Se y maior que qualquer SEUWRITE(x) para o objeto $x$

-então processe a leitura e SEUWRITE $(x)=\gamma$

- senão rejeite a leitura e submeta novamente a transação. 
- Se for uma operação de escrita $W(x)$ com número de senha = $\gamma$ então:

- Se y maior que qualquer SEUWRITE(x) ou SEUREAD(x)

-então processe a escrita e SEUWRITE $(x)=\gamma$

- senão rejeite a escrita e submeta novamente a transação.

-As transações novamente submetidas recebem um número de senha maior que $a$ anterior.

Entretanto esta implementação básica apresenta três problemas: -armazenamento das variáveis $\operatorname{SEUREAD}(x)$ e SEUWRTE( $(x)$ para cada objeto $x$ do sistema;

-interação com o protocolo bifásico de comunicação (2PL) reponsável pelas operaçōes de atualização dos demais nós da rede;

-as transações submetidas novamente podem entrar em reinícios cíclicos, e nunca serem processadas.

Uma possível solução para evitar-se a atribuição das variáveis $\operatorname{SEUREAD(x)~e~}$ SEUWRITE(x) para cada objeto consiste em manter-se duas tabelas com uma quantidade limitada dos valores de $\operatorname{SEUREAD}(x)$ e SEUWRITE(x), desconsiderando os valores mais antigos. Os mais recentes deverão ser armazenados em variáveis auxiliares. Assim, para cada objeto ter-se-iam as seguintes estruturas de dados:

-TabRead: tuplas da forma(x,SEUREAD(x));

-TabWrite: tuplas da forma(x,SEUWRTTE(x));

-MaxRead: maior valor de SEUREAD(x) que foi eliminado da tabela TabRead;

-MaxWrite: maior valor de SEUWRITE(x) que foi eliminado da talela TabWrite.

Estas tabelas funcionam através da substituição de tuplas, caso operem sobre um mesmo objeto. Se a tabela estiver cheia para inserção de uma nova tupla, retirar-se-a a tupla mais antiga e sua senha será comparada com MaxRead ou MaxWrite para possível atualização.

Como exemplo, seja uma transação que solicite do objeto x uma leitura. Logo, a tupla(x,w) terá que ser adicionada à tabela TabRead. Caso já exista uma tupla(x,u), esta será substituída por $(x, w)$.

Se a tabela estiver completa, uma tupla(z,r) será selecionada, segundo um critério pré-estabelecido, para ser retirada e sua senha r será comparada com MaxRead para atualização, se necessário. 
Isto posto, quando solicita-se a consulta do valor da senha de determinado objeto, pesquisa-se inicialmente a tabela de leitura ou escrita. Existindo uma tupla $(x, t)$ que satisfaça à pesquisa, $t$ é tomado como senha. Caso não exista o objeto em questão, então MaxRead ou MaxWrite $\epsilon$ tomado como valor da senha, que corresponderá sempre a um valor igual ou maior ao da verdadeira senha que se deseja encontrar.

Para o segundo problema, no qual o protocolo bifásico é utilizado para atualização dos demais nós da rede, dois tipos de mensagens sāo exigidos: Prepare e Confirme.

No início do protocolo, mensagens de "Prepare" são enviadas aos nós. Caso a transação seja aceita, as mensagens de "Confirme" são enviadas liberando as atualizaçōes. Dessa maneira, o tempo exato para avaliação da transação será no recebimento da mensagem Prepare e nāo no início das atualizaçōes propriamente ditas. Assim o mecanismo de controle de concorrência deverá avaliar as transações na medida em que receber mensagens Prepare, e garantir que nenhuma transaçāo de leitura ou escrita, será efetuada no objeto que está sendo atualizado pelo protocolo bifásico. Caso contrário, ocorrerá inconsistência dos dados. Uma das possíveis maneiras realizar-se isso e fazer com que as operaçōes de leitura e escrita pertencentes à transação em fase de atualização pelo protocolo bifásico recebam valores infinitos de senha, provocando o reinício de todas as outras transações que solicitem o mesmo objeto. Terminada a operação de atualização, as senhas voltam a ter seus valores verdadeiros. Esta solução pressupōe um bloqueio para garantir a consistência dos dados no momento da atualização dos diversos nós.

Com relação ao terceiro problema, uma transação pode não terminar se for reiniciada ciclicamente. Isto pode acontecer quando o acréscimo do tempo para atribuição das senhas gerar um sincronismo entre as transações conflitantes causando um reinício mútuo entre as mesmas. Por exemplo, seja a seqüência de transações Ti0,Ti1,Ti2,......,Tim-1,Tim de tal maneira que Tij força o reinício de $\mathbf{T i j}+1$.

Se o incremento do tempo da senha for constante, então tem-se a repetição da situação indefinidamente. Pode-se minimizar o reinício das transações utilizando incrementos aleatórios para as senhas. Esta solução não evita completamente o reinício ć́clico, entretanto diminui sua probabilidade de ocorrência.

\subsection{2 - Implementação Conservativa.}


A implementação conservativa [CER__84] utiliza filas para leitura e escrita em cada nó i pertencente à rede. $O$ controle de concorrência é feito localmente, onde o gerente de transações (GT), é encarregado de enviar os subcomandos para as filas acima mencionadas.

FilaRead(GT): fila com subcomandos enviados por GT para o no i para leitura na respectiva base de dados.

FilaWrite(GT): fila com subcomandos enviados por GT para o nó i que atualizam a respectiva base de dados.

Cada elemento da fila contém a especificação da senha. $O$ mecanismo para controle de concorrência se limita portanto a:

- esperar que todas as filas contenham algum comando;

- selecionar o subcomando com a menor senha e processá-lo.

Com isto, a implementação conservativa elimina o problema do protocolo bifásico que ocorre na implementação básica, e nunca força o reinício das transações. Entretanto, exigirá uma comunicação mais intensa entre os gerentes de transaçōes de cada nó para selecionar o subcomando de menor senha e durante esta escolha, as transaçōes ficam bloqueadas.

Caso um nó i não receba transaçōes, o protocolo pode ficar paralizado, pois o mecanismo de controle de concorrência pressupōe subcomandos na fila referente ao nó i. Se a fila permanecer vazia, ocorrerá um bloqueio perpétuo.

Este problema pode ser contornado, fazendo-se com que cada gerente de transação envie periodicamente mensagens de controle a todos os nós com que se comunica, contendo a senha corrente, mesmo que os nós não recebam subcomandos das transações.

Dessa maneira, é possível fazer com que não haja bloqueio perpétuo. Entretanto, devido à comunicação adicional entre os gerentes e os nós, torna-se proibitiva tal implementação num ambiente de grande porte.

\subsection{3 - Implementação Baseada em Versōes Múltiplas.}

O objetivo da implementaçāo baseada em Versōes Múltiplas [CERI_84], [DATE_88], [CASANOVA_84] é manter um histórico com todas as versōes de atualizações dos objetos, juntamente com seus respectivos valores de senha.

Pretende-se com isto minimizar o reinício das transações, na medida em que 
dispōe-se de um histórico do objeto. Quanto maior o número de versōes registradas, menor será o índice de rejeição das transações de escrita e praticamente nulo o reinício das transações de leitura.

Estrutura de Dados para implementação de versões múltiplas:

SeqRead(x): seqüência de todas as senhas das açōes de leitura para o objeto $x$. Versōes( $\mathrm{x}$ ): seqüência contendo todas as versões de $\mathrm{x}$, com tuplas da forma $(\mathrm{s}, \mathrm{V})$; $s=$ senha, $V=$ versão de $x$.

Mecanismo de Controle de Concorrência para versōes múltiplas:

a)Seja $R(x)$ uma leitura com senha r. Selecione a tupla(s,V) onde s é a maior senha em Versōes $(x)$, entretanto menor que r:

-V é o valor de $x$ para $R(x)$;

-Insere-se $r$ em SeqRead(x), respeitando a ordenação.

b) Seja $W(x)$ uma escrita com senha $w$, e ainda $t(x)$ a menor senha em Versöes $(x)$ maior que w:

-Se existe alguma versão de $x$ e alguma senha r em SeqRead(x), tal que $w<r<t(x)$, então a operação gerará inconsistência e terá que ser rejeitada;

-caso contrário, processe a atualização, criando um novo par ( $w, V$ em Versōes $(x)$.

Esta implementação, poderá utilizar uma quantidade de memória adicional que a tornará proibitiva. Pode-se atenuar esta sobregarga, mantendo cópias apenas das últimas versōes criadas, limitando assim o tamanho das tabelas SeqRead(x) e Versões(x) e permitindo, a um custo plausível, diminuir o volume das transaçōes reiniciadas.

Nesta implementação o problema com o protocolo bifásico, ocorrerá da mesma forma que na implementação básica, sendo resolvido de forma semelhante.

\section{5 - CONCLUSÃO.}

Um quadro geral, comparando os métodos de gerenciamento e controle de concorrência extraído de [CASANOVA_84], é apresentado através da figura 2.7. Nesta figura mostram-se todos os métodos, comparados em funçāo da Estrutura de Dados, 
Mensagens Adicionais, Existência de Cópias e Problemas de Conclusão da Transaçāo

\begin{tabular}{|c|c|c|c|c|c|}
\hline \multirow{2}{*}{\multicolumn{2}{|c|}{ IMPLEMENTAÇÃO }} & \multirow{2}{*}{\multicolumn{4}{|c|}{ Caracterf́sticas }} \\
\hline & & & & & \\
\hline \multirow[t]{3}{*}{ BLOQUEIO } & Básica & $\begin{array}{l}\text { tabela de } \\
\text { bloqueios } \\
\text { distribuída }\end{array}$ & $\begin{array}{c}\text { não são } \\
\text { necessárias }\end{array}$ & $\begin{array}{c}\text { não } \\
\text { reconhece }\end{array}$ & $\begin{array}{l}\text { bloqueios } \\
\text { mútuos } \\
\text { difíceis de } \\
\text { detectar }\end{array}$ \\
\hline & $\begin{array}{c}\text { Cópias } \\
\text { Primárias }\end{array}$ & $\begin{array}{c}\text { tabela de } \\
\text { bloqueios } \\
\text { para cópias } \\
\text { primárias }\end{array}$ & $\begin{array}{l}\text { bloquear } \\
\text { copias } \\
\text { primárias }\end{array}$ & reconhece & $\begin{array}{l}\text { bloqueios } \\
\text { mútuos } \\
\text { diff́ceis de } \\
\text { detectar }\end{array}$ \\
\hline & Centralizada & $\begin{array}{l}\text { tabela de } \\
\text { bloqueios } \\
\text { centralizada }\end{array}$ & $\begin{array}{c}\text { bloquear } \\
\text { n6 } \\
\text { coordenador }\end{array}$ & $\begin{array}{c}\text { nāo } \\
\text { reconhece }\end{array}$ & $\begin{array}{l}\text { bloqueios } \\
\text { mútuos } \\
\text { fáceis de } \\
\text { detectar }\end{array}$ \\
\hline \multirow[t]{3}{*}{$\begin{array}{c}\text { PRÉ- } \\
\text { ORDENAÇÃo }\end{array}$} & Básica & $\begin{array}{c}\text { listas de } \\
\text { senhas }\end{array}$ & $\begin{array}{c}\text { não são } \\
\text { necessárias }\end{array}$ & $\begin{array}{c}\text { não } \\
\text { reconhece }\end{array}$ & $\begin{array}{c}\text { reinício } \\
\text { ć́clico e } \\
\text { mútuo de } \\
\text { fácil } \\
\text { solução }\end{array}$ \\
\hline & $\begin{array}{c}\text { Conservati- } \\
\text { va }\end{array}$ & $\begin{array}{l}\text { listas de } \\
\text { senhas e } \\
\text { versōes }\end{array}$ & $\begin{array}{c}\text { não são } \\
\text { necessárias }\end{array}$ & $\begin{array}{c}\text { não } \\
\text { reconhece }\end{array}$ & $\begin{array}{c}\text { bloqueios } \\
\text { eternos }\end{array}$ \\
\hline & $\begin{array}{l}\text { Versões } \\
\text { Múltiplas }\end{array}$ & $\begin{array}{l}\text { listas de } \\
\text { senhas e } \\
\text { versōes }\end{array}$ & $\begin{array}{c}\text { não são } \\
\text { necessárias }\end{array}$ & $\begin{array}{c}\text { não } \\
\text { reconhece }\end{array}$ & $\begin{array}{l}\text { reinício } \\
\text { cíclico e } \\
\text { mútuo de } \\
\text { fácil } \\
\text { solução }\end{array}$ \\
\hline
\end{tabular}

Fig.27: Quadro comparativo dos Mecanismos de Controle de Concorrência

E muito difícil comparar as várias formas de controle de concorrência apresentadas, sem especificar o ambiente e as características da base de dados em que se insere tal controle de concorrência. Entretanto pode-se levantar alguns parâmetros que auxiliam na decisão:

-custo adicional de comunicação: número de mensagens necessárias utilizadas para o controle de concorrência;

-custo adicional de processamento local: tempo gasto em processamento para o controle de concorrência; 
-custo adicional de processamento de transaçōes: tempo que uma transação é bloqueada ou número de vezes que é reiniciada.

Existem duas abordagens para analisar os mecanismos de controle de concorrência:

-pessimista: alto nível de transaçōes conflitantes;

-otimista: baixo nível de transaçōes conflitantes.

Numa abordagem pessimista, considera-se que a porcentagem de conflitos é muito alta. $O$ objetivo então é diminuir o custo para resolver tais conflitos. Deve-se escolher um mecanismo que minimize as transações reiniciadas. Na abordagem otimista, considera-se uma taxa pequena de conflitos, e deve-se portanto escolher um mecanismo que minimize o custo para gerenciar ou prever tais conflitos.

No caso de pré-ordenação tem-se duas opgōes: uma é a conservativa, e nunca reinicia as transações, mas em contrapartida gera um volume considerável de mensagens adicionais; a outra é a de versões múltiplas, que utiliza uma estrutura de dados que ocupará mais memória.

No caso do bloqueio em duas fases, o protocolo centralizado é o mais indicado pois num cenário pessimista bloqueios mútuos serão muito freqüentes, e a forma centralizada permite fácil deteção/solução dos bloqueios mútuos.

No caso otimista, de modo geral, as opçōes do mecanismo de controle de concorrência se igualam na eficiência, pois a percentagem de ocorrência de conflitos é muito baixa. Dessa maneira, quando ocorre o conflito, o tempo que o sistema gastará para atender tal conflito, será pequeno em relação as operaçōes realizadas sobre a base de dados. 


\section{Capítulo 3 \\ CONTROLE DE INTEGRIDADE}

\section{1 - Falhas no Sistema de Base de Dados.}

Todos os Sistemas de Base de Dados estāo sujeitos a falhas de hardware ou de software [CASANOVA_84], [CERI_84] e [DATE_88]. Estas falhas comprometem parcial ou totalmente a integridade da Base de Dados. Portanto, um SGBD deve conter mecanismos que diminuam acentuadamente os efeitos de tais falhas.

De modo simples, a única maneira de garantir a integridade dos dados contra falhas é a redundância dos mesmos no sistema [KOHLER_81], [LORIE_T] e [SKEEN_83]. $\mathrm{Na}$ ocorrência de um determinado tipo de falha interferindo sobre um conjunto de dados, o sistema poderá se recompor através da ativação da respectiva cópia. $\mathrm{Na}$ medida em que a Base de Dados é dinâmica, ou seja, transações alteram os dados contidos na Base ao longo do tempo, é necessário que as operaçōes de redundância sejam acionadas freqüentemente, de modo a garantir que no caso da ocorrência de uma falha, o sistema possa ativar a cópia mais recente anterior a referida falha.

As falhas de hardware e software podem ser melhor especificadas através da classificação dos elementos envolvidos:

a) procedimentos: referem-se a todos os programas aplicativos que compõem o SGBD.

b) processadores: processador central, processadores em unidades de controle de periféricos, terminais, modem, etc. 
c) memoria principal ou volatil: corresponde à memória RAM. As falhas que ocorrem afetando este tipo de memória, como interrupção de energia elétrica, defeitos nos processadores ou procedimentos, denominam-se falhas primárias.

d) memória secundária ativa: são as memórias dos dispositivos físicos de $\mathrm{E} / \mathrm{S}$, como discos e fitas magnéticas, onde a Base de Dados é armazenada. Normalmente utilizam-se discos magnéticos pelas suas características de acesso aos dados. As falhas primárias não interferem na memória secundária ativa. Estas falhas, chamadas secundárias, se caracterizam por defeitos nos cabeçotes de leitura/escrita ou partículas indesejáveis na superficie dos discos, que acabam por provocar perda de setores e/ou trilhas, destruindo assim parte da Base de Dados armazenada.

e) memória secundária dormente: esta memória se caracteriza pelo fato de nāo ter algum vínculo com o sistema em funcionamento. Devido à sua grande capacidade de armazenamento de dados utilizam-se normalmente fitas magnéticas para cópia de todo Sistema de Base de Dados. O objetivo é garantir que numa eventual falha secundária onde todo ou parte dos dados são danificados, o sistema possa ser recuperado pelo menos com a versão mais recente gravado em fita magnética. Tal versão em fita magnética não necessariamente é a que o sistema dispunha no momento da falha. São chamadas falhas terciárias e inutilizam ou destroem o conteúdo da memória secundária dormente. Como exemplo, tem-se incêndios, furtos ou outros incidentes afins.

f) cancelamento de transaçōes: neste caso, não se tem as falhas dos componentes do sistema. Entretanto, por motivo de controle de concorrência, ou até mesmo a pedido do usuário, transações são canceladas. Estes acontecimentos são chamados de pseudo-falhas do sistema, que deverão ser tratados pelos mecanismos de controle de integridade, com intuito de desfazer os possíveis efeitos das operaçōes pertencentes às transaçōes canceladas.

Além da classificação das falhas, é preciso associá-las com a frequêencia com que ocorrem na prática, e também com o tempo necessário para que o controle de integridade recomponha a Base de Dados. A figura 3.1, extraída de [CASANOVA_84] sintetiza tal situação. 


\begin{tabular}{|c|c|c|}
\hline Tipo de Falhas & Freqũência & Recuperação \\
\hline pseudo-falha & algumas/minuto & milisegundos \\
\hline primária & algumas/mês & segundos \\
\hline secundária & algumas/ano & minutos \\
\hline terciária & algumas/século & dias \\
\hline
\end{tabular}

Fig.3.1: Classificação e freqũência das falhas.

As falhas descritas até o momento foram consideradas indepentes uma das outras, de modo que o efeito cascata, onde falhas provocam outras falhas, é desconsiderado. Após a descriçāo dos possíveis tipos de falhas, pode-se afirmar que a elaboração de um sistema controlador de integridade capaz de dar proteção total à Base de Dados é impossível. Isto pode ser exemplificado pela imprevisibilidade da ocorrência de falhas, pois no momento em que o sistema está se recuperando de um determinado tipo de falha, outros tipos podem ocorrer de modo a caracterizar falhas simultāneas. Portanto os mecanismos de proteção objetivam tornar o SGBD cadạ vez mais confiável. No entanto, isto só pode ser realizado a custo de um aumento de sofisticaçāo. Esta sofisticaçāo tem limites. Ela não pode permitir um custo absurdamente alto na implementação de suas estruturas, pois inviabilizaria o próprio SGBD.

Antes de começar a descrever os mecanismos para controle de integridade que estāo intimamente ligados ao Gerenciador de Transação (GT), é preciso definir detalhadamente o conceito de Estado de Transação.

Quando uma transação T é submetida em um determinado nó, o Gerenciador de Transaçāo em questāo assume o controle do processamento de T. Com isto, o estado da transação $T$ submetida pode estar nas seguintes situações abaixo descritas:

- ativo: estado inicial da transação, na qual o GT identifica de maneira unívoca cada ação elementar pertencente à transação em questão;

- parcialmente confirmado: após a execução da última ação pertencente à transaçāo excluindo a instrução FIM-DE-TRANSAÇĀO;

- cancelado: por motivo de controle de concorrência, falhas ou mesmo a pedido do 
usuário, a execução do conjunto das ações elementares é interrompida;

- confirmado: após a execução da instrução FIM-DE-TRANSAÇÃO onde as alteraçōes realizadas já se encontram gravadas em memória secundária.

- excluído: a transação foi cancelada e não mais submetida a execução.

A figura 3.2 apresenta o diagrama de estados da transação, onde tem-se os caminhos possíveis que uma transação pode percorrer quando está sendo submetida a execução.

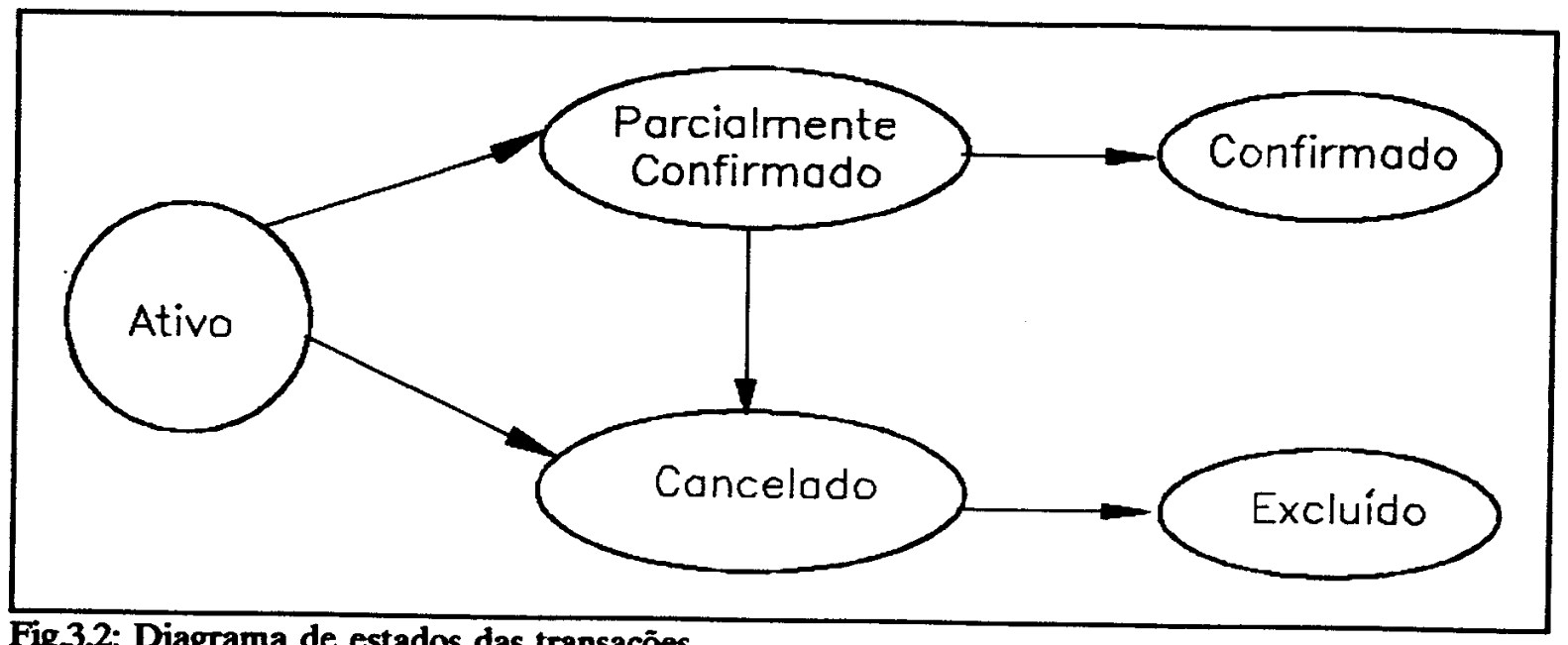

Fig.3.2: Diagrama de estados das transaçóes.

\section{2 - Mecanismos de Controle de Integridade.}

\subsection{1 - Programas Restauradores.}

Os programas restauradores atuam após a ocorrência de algum tipo de falha tentando recuperar o máximo possível de dados consistentes. Alguns arquivos podem ser perdidos, se não atenderem os critérios de consistência subjacente ao algoritmo Restaurador. Desta forma, este método garante que a Base de Dados permaneça consistente, entretanto incompleta.

Estes programas atuam em situações de transferência de conteúdo da memória principal para memória secundária. $\mathrm{Na}$ ocorrência de falhas que interrompam tais processos, o programa restaurador verificará os arquivos em memória secundária, 
avaliando a consistência dos mesmos, para determinar se é possfivel a recuperação ou, em casos críticos, a eliminação dos arquivos envolvidos.

Este método é utilizado como último recurso para garantir a integridade da Base de Dados. Normalmente está associado a sistemas que pressupõem que os dados estejam alocados em outras formas de armazenamento, de modo que os eventuais arquivos ou dados eliminados possam ser recompostos através de consultas a versōes imediatamente anteriores às falhas.

Embora seja um método primitivo de controle de integridade, os Programas Restauradores têm validade em sistemas de Base de Dados com estruturas de dados elementares.

\subsection{2 - Descargas.}

Este método transfere periodicamente (descarrega) todo o conteúdo da memória secundária para outros dispositivos de armazenamento, normalmente fitas magnéticas, as quais por sua vez serão arquivadas como memória secundária dormente. Numa eventual falha onde os mecanismos de controle de integridade mais sofisticados não possam atuar, a Base de Dados pode ser recomposta com a versão da última descarga. Portanto as transaçōes em andamento ou concluídas após a última descarga serão desconsideradas.

Uma alternativa para tornar a transferência de dados mais eficiente é a descarga incremental. Esta consiste na transferência apenas dos dados que foram alterados desde a última descarga.

Descargas devem atuar em conjunto com outros mecanismos de controle de integridade. Como exemplo, um sistema simples poderia conter os Programas Restauradores em sintonia com as Descargas, no qual arquivos que porventura se mostrarem impossíveis para a recuperação através dos Restauradores, seriam recompostos com sua última versão através da consulta à memória secundária dormente, gerenciada pelo mecanismo de descarga.

A periodicidade com que realizar-se-ão as descargas dependerá das características da Base de Dados envolvida. Quanto maior for a freqüência da ocorrência das descargas, mais eficiente será o mecanismo de recomposição do sistema, pois as versões serão mais recentes em relação ao momento da ocorrência da falha. 
Entretanto, isto acarretará um comprometimento do tempo de resposta do sistema.

As Descargas podem ser implementadas de duas maneiras:

a) estática: o SGBD interrompe as transaçōes por um determinado momento e aciona o mecanismo de descarga. No fim da operação de transferência, o SGBD retoma a execuçāo das transaçōes anteriormente bloqueadas.

b) dinâmica: o SGBD realiza as descargas, entretanto fica disponível para a execução de algumas transaçōes com um tempo de resposta comprometido. Esta implementaçāo garante que a partir de um referencial de tempo t, apenas as transações finalizadas antes de $\mathbf{t}$ terāo suas atualizaçōes refletidas na cópia descarregada.

\subsection{3 - Arquivos Diferenciais.}

Este método pressupõe que as alterações da Base de Dados sejam registradas em arquivos auxiliares chamados diferenciais, com o objetivo de preservar o arquivo original. Assim, ocorrendo uma falha na transferência dos dados da memória principal para o arquivo diferencial, o SGBD restauraria a consistência através da consulta da cópia original em memória secundária.

Há dois problemas para manter a integridade dos dados decorrentes desta concepção: o primeiro se refere à perda das transaçōes já confirmadas e registradas no arquivo diferencial mas não na base, no momento da falha, que pode ser minimizado, a um custo de degradaçāo do sistema, através da duplicação dos arquivos diferenciais; o outro é o processo de consulta aos dados que inicialmente deverão ser pesquisados nos arquivos diferenciais; caso nāo encontrados a pesquisa recairá sobre o original. Este processo de pesquisa, que dificilmente pode ser otimizado, ocasionará perda de eficiência na resposta do sistema.

O método descrito acima tem a seu favor uma melhor eficiência nas descargas incrementais, pois os arquivos diferenciais, a princípio, devem ser bem menores que os originais.

O arquivo diferencial no seu início de ativação, solicita os objetos do arquivo original que deverão ser atualizados pela transaçāo. Ao invés de copiar novamente para o arquivo de origem, a nova versão do objeto é registrada num outro arquivo juntamente com a especificação do objeto, de modo que no momento em que houver 
a descarga, ou seja, a atualizaçāo dos arquivos origem pelos respectivos objetos que constituem o arquivo diferencial, não ocorra inconsistência dos dados.

Há entretanto a possibilidade da falha no momento da descarga. Para contornar este problema, o mecanismo de descarga pode incorporar os comandos INICIO e FIM do processo de atualização. Ao estado FIM, pressupõe que todos os objetos do arquivo origem foram substituídos pelo respectivo valor do arquivo diferencial, configurando uma situaçāo de sucesso da operaçāo. Aṕ́s isto, o arquivo diferencial pode ser "zerado" e ser colocado a disposição para acumulação dos novos objetos.

Se ocorrer uma falha antes do mecanismos atingir o estado FIM do Processo de Atualização, o processo de descarga terá que ser reiniciado. Isto sugere que falhas sincronizadas podem levar o mecanismo de descarga a nunca efetivar a devida atualização. Pode-se contornar este problema diminuindo o tamanho do arquivo diferencial, ou então segmentando o arquivo diferencial para operação de atualização, com a utilização de pontos de verificação (checkpoints).

\subsection{4 - Atas ( $(\mathrm{Log})$.}

O método de controle de Integridade através de Atas tem como proposição fundamental o conceito de transaçāo como unidade básica para operaçōes sobre a Base de Dados. Quando ocorre alguma falha, transaçōes são interrompidas em pleno andamento. Assim que o Sistema de Base de Dados superar a falha, este terá que desfazer as alterações parciais causadas pelas transações em andamento na ocasião da falha.

Para realizar esta tarefa, cada operação elementar deve ser registrada em uma "Ata", a qual deverá conter os valores iniciais e finais de cada objeto envolvido, bem como a transação responsável por tal modificação. Esta Ata deve ser gravada em memória secundária para que o Sistema de Base de Dados, ao se recompor, possa consultá-la e agir de acordo com a situação de cada transação de modo a:

- desfazer as alteraçōes realizadas pelas transaçōes em andamento no momento da falha;

- retomar, através da Ata, as transaçōes confirmadas, entretanto não registradas em memória secundária. 
A Ata deve conter ainda o registro do início e fim de cada transaçāo submetida, de modo a permitir que o Sistema de Base de Dados identifique as transaçôes em andamento no momento da falha.

Com isto, o método de Integridade através de Atas consiste em obter algoritmos que garantam o sincronismo entre a entrada dos registros das operaçōes elementares na Ata e as alterações dos objetos em memória secundária. Abaixo, apresentam-se os passos importantes para implementação do método em questão, considerando que os registros em Ata antecedem as operaçōes em memória secundária:

- pesquisa-se a página para localização do objeto requisitado pela transação, transportando-a para memória principal caso necessário;

- executam-se as alteraçōes necessárias na referida página;

- registra-se, em Ata, a operação elementar contendo valores iniciais e finais dos objetos envolvidos, com sua respectiva transação;

- reescreve-se a página da memória principal para secundária

Uma característica inerente a este método (Atas) é o fato de conter todo o histórico das alterações, incluindo as transaçōes já executadas. Para evitar esta grande quantidade de informações desnecessárias em Ata, que comprometeria a eficiência do Sistema de Base de Dados, utilizam-se Descargas. Estas avaliam de acordo com um determinado intervalo de tempo o estado de cada transação registrada em Ata. Se as transaçōes já estiverem concluídas antes do momento da descarga, então serão descartadas da Ata. As restantes são mantidas com as mesmas informaçōes.

\subsection{5 - Imagens Transientes.}

No caso das imagens transientes, considera-se que a memória secundária está dividida em blocos, e que estes sāo a menor unidade para leitura/gravação, os quais podem ter o mesmo tamanho da página que é a menor divisão da Base de Dados. Portanto um objeto constituído de várias páginas é descrito por um conjunto de blocos, no qual seus endereços estão listados num diretório de blocos. Ao se executar uma transação, ao invés de reescrever as possíveis alterações nos blocos que correspondem à versão original dos objetos envolvidos, alocam-se novos blocos e 
transcreve-se para a memória secundária a nova versão. Uma vez confirmada a gravação, atualiza-se o diretório com os novos endereços dos blocos, liberando assim os blocos da versão original.

Este método objetiva garantir que na passagem da mémoria principal para secundária, seja mantida a integridade dos dados. Para isso, o método consiste em alocar blocos livres em memória secundária para as alterações, mantendo os blocos originais intactos. Somente após a confirmaçāo do sucesso da operação de gravação, libera-se os blocos que correspondem a versão original.

De maneira mais detalhada, o método consiste em :

a) carregar o bloco desejado da memória secundária para memória principal;

b) processar as alteraçōes necessárias no referido bloco;

c) pesquisar um bloco livre na memória secundária;

d) reescrever o bloco da memória principal para o bloco livre encontrado na memória secundária;

e) alterar o diretório de páginas, atualizando-o com o endereço do novo bloco;

f) liberar o bloco ocupado anteriormente pela página

Com isto, cria-se uma imagem dos objetos a serem alterados pelas transações. Estas imagens substituirão os originais, uma vez confirmado o processo de gravação em memória secundária. Se porventura ocorrer uma falha no sistema durante a criação da imagem transiente, as originais estariam inalteradas e representariam o estado consistente mais recente da Base de Dados.

Pode-se implementar o método das imagens transientes através de vetores de ponteiros ou listas de intençōes.

No caso de vetores de ponteiros, considera-se a Base de Dados dividida em segmentos que contém um conjunto de páginas. Para cada segmento, ao invés de alocar o conteúdo das páginas, tem-se um vetor de ponteiros para o endereço dos blocos de suas respectivas páginas. Além disto, supõe-se a existência de dois vetores de bits para registrar a situação dos segmentos e blocos da Base de Dados. Um, é o vetor chamado mapeador ou resumidamente BITMAP, onde o i-ésimo bit representa a situação do i-ésimo bloco da memória secundária: 1 ocupado e 0 livre. O outro, chamado Estado representa a situação do i-ésimo segmento: 1 alocado na memória 
principal, significando que transações estão manipulando páginas deste segmento, e 0 caso disponivel.

Apresentam-se abaixo os principais passos que deve conter o algoritmo para atualização de uma determinada página de um segmento:

a) consultar o vetor de bit(Estado) para identificar se o segmento a ser alterado já näo está sendo utilizado na memória principal por outras transaçōes;

b) caso não esteja, copiar o conteúdo do vetor Vj do segmento desejado em um outro vetor Vj'em memória secundária;

c) trazer o bloco de endereço $V j(k)=y$, que corresponde à página que seră alterada para a memória principal;

d) fazer as operaçōes de atualizaçōes da página na memória principal;

e) pesquisar um bloco livre $(x)$ da memória secundária através do vetor MAP;

f) transcrever a página da memória principal para memória secundária no bloco de endereço $x$;

g) alterar o conterido de $V j(k)=y$ para $V j(k)=x$;

h) copiar o vetor BITMAP num outro vetor BITMAP' em memória secundária;

i) liberar o bloco do vetor BITMAP fazendo BITMAP(y)=0 e BITMAP(x)=1;

j) liberar os blocos utilizados por BITMAP' e Vj'.

Os passos b) e h) garantem que em caso de falha, o sistema de Base de Dados possa se recompor ao seu estado anterior, transferindo o conteúdo dos vetores Vj' e MAP' para os Vj e MAP.

A outra maneira de implementar o método de Imagens Transientes é utilizando listas de intençōes. Este considera que cada arquivo está dividido em páginas e que a própria Base de Dados armazena num diretório $\mathrm{D}$ os blocos onde as páginas do arquivo se encontram.

Portanto, ao se processar as transaçōes criam-se imagens transientes, analogamente a técnica de vetores de ponteiros, de forma que o arquivo com uma determinada página de $\mathrm{P} 1, \ldots . ., \mathrm{Pn}$ tenha os endereços originais $\mathrm{X} 1, \ldots . ., \mathrm{Xn}$ e os transientes $\mathbf{Y} 1, \ldots$ Yn. Após esta operação, o diretório terá que ser atualizado. Para isso, uma lista de açōes contendo as alteraçōes necessárias para $D$ deverá ser executada. Esta lista de ações $\mathrm{L}=(\mathrm{A} 1, \ldots . ., \mathrm{An})$ é chamada de lista de intenções, onde os $\mathrm{Ai}$ representam as alterações em $\mathrm{D}$ para as novas versōes de $\mathrm{Pi}$. 
Com o objetivo de detalhar a técnica acima descrita, apresentam-se os seguintes passos:

a) transaçōes geram imagens transientes das páginas $(P 1, \ldots, P n)$ de um determinado arquivo de diretório $D$;

b) cria-se a lista de intenções $L$ para atualização de D;

c) gravar L em memória secundária por motivo de segurança;

d) atualizar o diretório $D$, executando a lista de intençōes $L$;

e) liberar o espaço ocupado por L na memória secundária.

Até o passo c), se ocorrer alguma falha no sistema, as alterações serão ignoradas pois o diretório $D$ não sofreu nenhuma alteração em relaçāo ao estado anterior. Após o passo c) o sistema terá condiçōes de retornar as alteraçōes recuperando a lista de intençōes gravada em memória secundária através da atualização de $\mathrm{D}$.

\section{3 - Protocolo de Bloqueio Bifásico para Comunicações.}

Em um sistema de Base de Dados Distribuída, replicado ou particionado, uma vez gerada uma transação em um determinado nó, esta precisa ser repassada para outros nós pertencentes à rede para a devida atualizaçāo. Para realizar esta tarefa é necessário um protocolo de comunicação entre os nós, que incorpore mecanismos de proteção contra falhas que possam gerar inconsistência na Base de Dados Distribuída.

Para estabelecer o protocolo de atualização é preciso estabelecer o nó centralizador e os demais nós participantes (nós remotos) da operação. Normalmente, num sistema distribuído, o nó gerador da transação é eleito como coordenador e será responsável pela inicialização do protocolo de atualização que é composto em duas fases: a primeira, consiste na preparação do ambiente para inicializar o protocolo; e a segunda, na confümação das operações solicitadas.

O Protocolo descrito acima é denominado Protocolo Bifásico, no qual o nó coordenador, gerencia as atualizaçōes diante dos demais nós participantes, enviando mensagens: PREPARE (primeira fase) e CONFIRME (segunda fase). Este protocolo também é utilizado quando transações executadas no nó coordenador, solicitam 
recursos de outros nós participantes (nós remotos) para realização de determinadas operações. Tanto neste caso, como nas atualização de dados resultantes de transaçōes realizadas em um único no, pressupōe-se um armazenamento resumido das informaçōes de toda a Base de Dados em cada nó.

A seguir apresenta-se o Protocolo Bifásico, que tem como critério básico para garantir a integridade das informaçōes a serem enviadas, a gravação em memória secundária do resultado de cada etapa do Protocolo de Comunicaçāo, de modo que, na ocorrência de falhas, o sistema gerenciador possa recompor-se ao estado anterior sem causar inconsistência dos dados ou das operaçōes.

\section{PRIMEIRA FASE}

\section{Coordenador:}

- Inicia o processo do envio de mensagens registrando este estado em memória secundária;

- Verifica os nós participantes enviando a mensagem PREPARE, juntamente com a lista de objetos que serão utilizados no processo de atualização;

- Aguarda a resposta dos nós participantes. Caso nāo receba a resposta de um ou mais nós participantes ou a resposta seja negativa, o nó coordenador aborta a transaçāo, envia mensagem de cancelamento da atualizaçāo aos nós remotos, e restaura o ambiente local no momento anterior ao início do Protolo de Comunicação.

\section{N6 Remoto:}

- Ao receber a mensagem PREPARE, tenta interromper as atividades locais, salvando-as em local seguro;

- Registra o resultado da operação acima (sucesso ou não);

- Envia ao nó coordenador o resultado da operação registrada no item anterior,

- Aguarda a resposta do Coordenador no que se refere a continuidade ou não do Protocolo de Comunicação. Caso a resposta seja negativa ou não a receba, este cancelará as operaçōes realizadas, retomando ao ambiente anterior ao momento do início do Protocolo de Comunicação. 


\section{SEGUNDA FASE}

\section{Coordenador}

- Analisa as respostas dos nós remotos e define a situação de conclusão ou não da transaçāo;

- Registra em local seguro tal análise;

- Envia aos nós participantes o conjunto de operações que constituem as transaçōes, juntamente com a mensagem CONFIRME;

- Aguarda a mensagem dos nós participantes confirmando ou não as atualizaçōes enviadas. Caso não receba a resposta ou seja negativa, abortará a transação, restaurando o ambiente anterior ao início do Protocolo de Comunicação.

\section{Nó Remoto}

- Recebe as devidas atualizaçōes do coordenador e tenta executá-las;

- Grava em memória secundária o sucesso ou nāo de tais atualizaçōes;

- Envia ao coordenador a resposta do item anterior, confümando ou não a transação;

- Recompóe o nó de acordo com o estado anterior ao início da execução do Protocolo de Comunicação.

\section{N6 Coordenador}

- Após receber a mensagem CONFIRME de todos os nós remotos, conclui a transação.

O Protocolo Bifásico pressupõe que os problemas da comunicação entre os nós restringem-se apenas ao fato das mensagens serem ou não recebidas pelos destinatários. Portanto, problemas relacionados com a deturpação dos dados são considerados de responsabilidade exclusiva da rede de comunicação entre os nós. Assim, para o Protocolo Bifásico, se a mensagem chega ao nó destino, os dados necessariamente são confiáveis. 


\section{4 - Conclusão.}

A tendência atual dos Sistemas Gerenciadores de Base de Dados no que diz respeito ao tratamento das possíveis falhas, é o de reagrupar das mais variadas formas os mecanismos, apresentados neste capítulo, visando cobrir um amplo espectro de falhas [STONEBRAKER_76], [HAMMER_79] e [GRAY_81]. Como exemplo, apresenta-se o Sistema R, [DATE_88], que utiliza uma combinação dos mecanismos de Arquivo Diferencial e Imagens Transientes.

Quando uma página é atualizada cria-se, de acordo com os critérios do mecanismo de Imagem Transiente, um novo bloco para alocar tais atualizaçōes, juntamente com as devidas alteraçōes do diretorio. Entretanto as páginas atualizadas só farão parte da Base de Dados e a versão anterior será desconsiderada, quando for ativado o processo de atualização da cópia original, que é uma característica do Arquivo Diferencial.

O Sistema $\mathbf{R}$ apresenta um recurso adicional para recuperação conhecido como savepoints. Este consiste na utilização dos comandos SAVE (registra o estado de transaçāo atual em um log) e RESTORE (retorna a transação ao estado imediatamente anterior registrado pelo SAVE), possibilitando o suporte para aninhamento de transaçōes.

Por definiçāo do Sistema Gerenciador, cada transação iniciada (BEGIN TRANSACTION) gerará o primeiro savepoint. Suponha-se que a transação A inclua um procedimento $B$, que deve ser atômico. Antes de chamar o procedimento $B$, a transação emite SAVE e posteriormente o RESTORE de acordo com o sucesso ou não da operação de B. A confirmaçāo da transação A dependerá do sucesso do procedimento $B$, pois os procedimentos aninhados constituem uma única transação caracterizada pelo primeiro savepoint. 


\section{Capítulo 4 \\ O MODELO DE REPRESENTAÇÃO DE OBJETOS}

\section{1 - Introdução.}

Traina Jr. sustenta em [TRAINA_88] e [TRAINA_91c], que os Sistemas de Gerenciamento de Bases de Dados (SGBD) disponf́veis atualmente foram em sua grande maioria desenvolvidos tendo por objetivo suportar aplicaçōes comerciais, nas quais a tônica consiste na manipulação de dados que podem ser organizados em um conjunto relativamente pequeno de estruturas, porém com um volume muito grande de dados estruturalmente idênticos. Por outro lado, aplicações não comerciais dos sistemas de computaçāo (que requerem um suporte não convencional por parte dos SGBDs), com frequência manipulam dados que não apresentam esta mesma homogeneidade estrutural. Nesse último caso, encontram-se os sistemas de Projeto Apoiado por Computador PAC(CAD), Fabricaçāo Apoiada por Computador - FAC (CAM), Sistemas de Automação de Escritório, Inteligência Artificial, etc.

As aplicaçōes que se desenvolvem nessas áreas em geral aproveitam os SGBDs que já existem, mesmo que estes não sejam adequados para essas aplicaçōes. Além disso, é muito frequente que duas ou mais aplicaçōes não convencionais, desenvolvidas de maneira independente, acabem tendo que ser integradas em um único sistema. Isso ocorre por exemplo quando um sistema de Projeto Apoiado por Computador deva ser integrado a um sistema de Fabricação Apoiado por Computador - PAC/FAC ou Sistemas de Fabricação Integrada (CIM) [SIMON_83]. Nesses casos, a falta de um núcleo de gerenciamento de dados comum traz problemas de compatibilidade entre os sistemas, sendo necessário então a criação de programas de adaptação complexos, e que em geral impedem a utilização plena das capacidades de pelo menos um dos sistemas integrados [LEATH_83], [SU_86]. 
Assim, têm sido pesquisados modelos para SGBDs que possam dar o suporte necessário a um amplo espectro de aplicaçōes não convencionais [HAMMER_81], [EARL_85], e portanto, que possam ser empregados em sistemas que devam ser integrados em sistemas maiores. Levantamentos de suas necessidades têm sido feitos e apresentados, tal como em [HARTZBAND_85], [BIC_86] e [NAVATHE_86], tendo-se tornado comum o termo Sistema de Gerenciamento de Dados para Engenharia (SGDE) para designá-los.

Um novo modelo de representação de dados denominado Modelo de Representaçāo de Objetos - MRO, apresenta características de construção de SGDEs que atendem a um amplo espectro de aplicaçōes, incluindo aplicaçōes integradas de projeto e produção de sistemas em geral e que, além disso, pode tirar proveito de arquiteturas de processamento pararelo, em especial, que pode ser executado com eficiência em arquiteturas de máquinas desenvolvidas especialmente para a sua execução [TRAINA_86]. Portando, apesar da grande demanda de recursos computacionais criada por modelos de alto conteúdo semântico, pode-se construir máquinas de base de dados que apresentem elevado desempenho com o MRO.

Tal como seu nome indica, o Modelo de Representação de Objetos possui o enfoque de ser orientado a objetos, devido ao fato de permitir a representação de informações tanto através de conjuntos de objetos estruturalmente semelhantes, quanto individualmente, permitindo tratar de cada objeto isoladamente, quando for o caso. Devido a isso, é um modelo que permite "ả representação de grande conteúdo semântico, adequado a sistemas de apoio à documentação e desenvolvimento de projetos, onde cada objeto de projeto tanto pode ser único, quanto podem existir conjuntos de dados semelhantes, tratados coletivamente. Além disso, o MRO permite a construção de MetaSistemas, em que a especificaçāo dos requisitos da própria aplicação devam ser mantidos na Base de Dados.

Para atender a tais necessidades é que foi desenvolvido o MRO [TRAINA_86] [TRAINA_88], seguindo o enfoque da orientaçāo a objetos, e sobre esse modelo foi construído um SGBD, denominado Gerenciador de Objetos - GEO [TRAINA_91a]. A seguir apresentam-se os principais conceitos de tal modelo, ilustrando-os através de um experimento de aprisionamento de átomos, bem como uma descrição da implementação do Gerenciador de Objetos para um ambiente mono-usuário e multi-usuário. 


\section{2 - Conceitos do Modelo de Representação de Objetos.}

\subsection{1 - Objetos.}

O MRO modela o mundo real através de Objetos. $O$ universo $U=\left\{o b_{b}, o b_{2} \ldots . ., o b_{n p} \ldots . . ..\right\}$ é o conjunto de objetos do mundo real que serão modelados no MRO.

Uma Base de Dados apoiada no Modelo de Representaçāo de Objetos será constituída por um conjunto finito de Objetos $\left\{o b_{p}, o b_{2}, \ldots . ., o b_{n}\right\}$ onde cada objeto definido por uma tupla $\langle i, I d o b, t o b>$, onde i é o código interno gerado pelo sistema que o identifica univocamente na Base de Dados, não sendo nunca reaproveitado, mesmo que o objeto deixe de existir. Idob é um conjunto de idenfícadores $I d o b=\left\{i d_{b}, \ldots, i_{\text {nidob }}\right\}^{*}$, onde $\mathrm{id}_{1}, \ldots \mathrm{id}_{\text {nidob }}$ são sinônimos e tob é o tipo de objeto, cuja função é a representação da abstração de objetos que contém características semelhantes.

\subsection{2 - Relacionamentos.}

As interações no mundo real entre os objetos podem ser representadas numa BD-MRO através de Relacionamentos. As abstrações desses relacionamentos são definidas como Tipos de Relacionamentos, que representam a interação nāo mais entre objetos, mas sim entre tipos de objetos. Tanto tipos de objetos como tipos de relacionamento são definidos no esquema de aplicação. Define-se ainda, a abstração de tipos de relacionamentos denominada de Modalidades de Relacionamentos. Tais conceitos são ilustrados na figura 4.1.

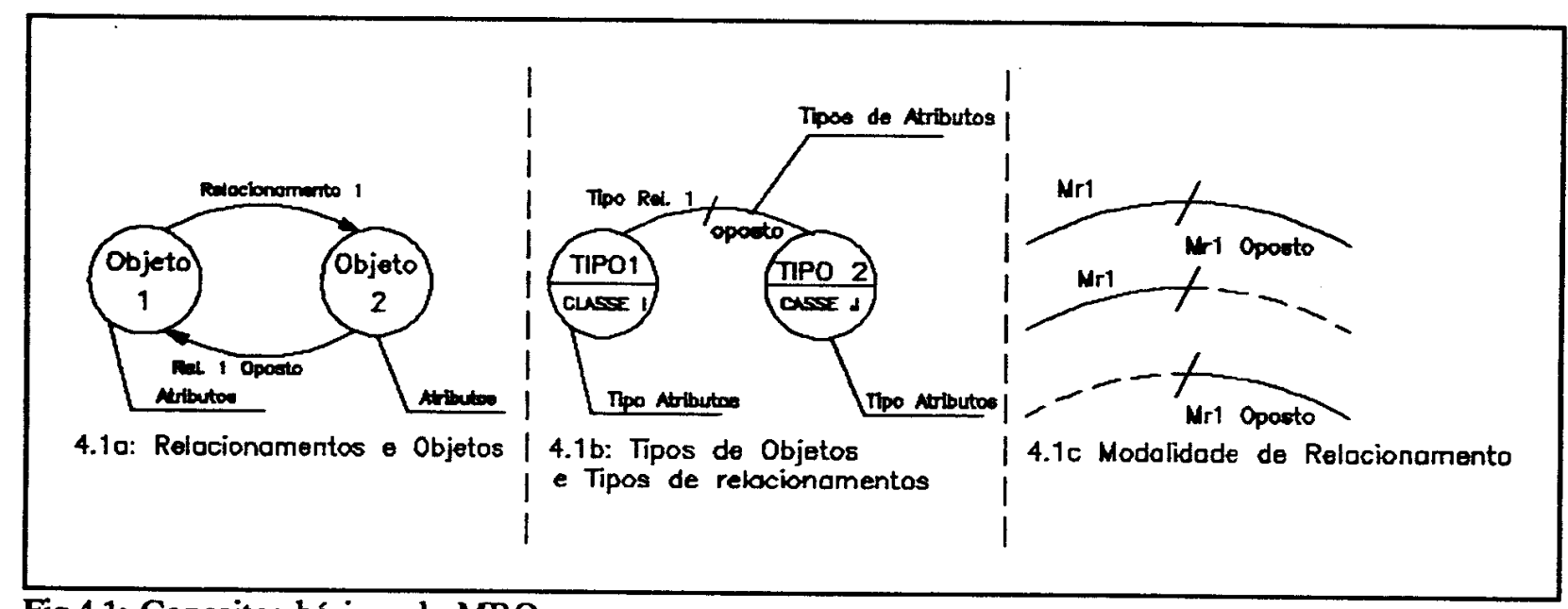

Fig.4.1: Conceitos básicos do MRO. 
Existem duas formas básicas de relacionamentos. Relacionamentos Binários ou simplesmente Relacionamentos, os quais sempre representam a interaçăo entre dois objetos, denominados Objeto Origem e Objeto Destino. Todo relacionamento segue um padrão definido no esquema, denominado tipo de relacionamento binário, que é uma tupla ordenada da forma $t r b=\left\langle t o b_{\omega} t o b_{\phi} m r_{i}\right\rangle$, onde estão determinados os tipos dos objetos origem e destino, bem como a modalidade do relacionamento.

Toda modalidade de relacionamento tem uma modalidade oposta, e portanto cada relacionamento tem um relacionamento oposto, em que os objetos origem e destino trocam de posiçōes.

A segunda forma de relacionamentos é chamada Relacionamento Triplo, ou simplesmente tripla, onde os objetos envolvidos podem assumir uma dentre três posiçōes distintas, denominadas Divisão1, Divisão2 e Divisão3. Todo relacionamento triplo segue um padrão definido no esquema da aplicação denominado Tipo de

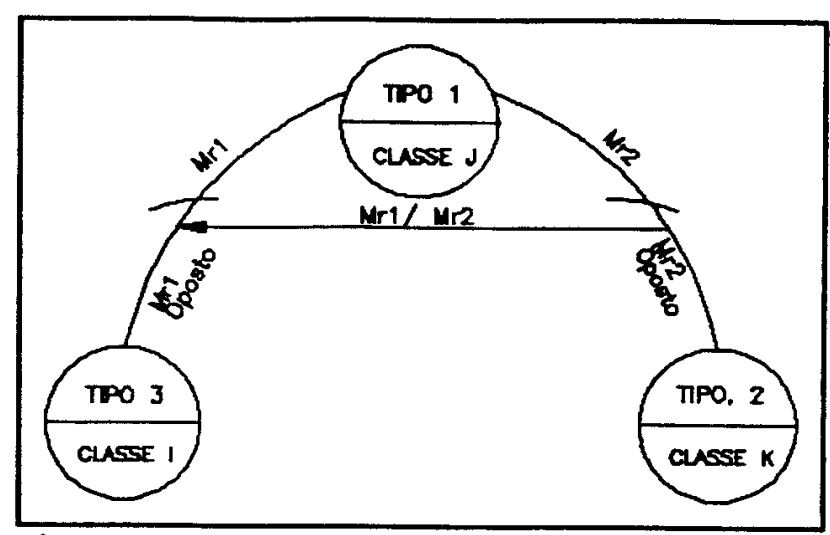

Fig.42: DRO para relacionamento triplo.

Relacionamento Triplo, o qual é uma tupla ordenada da forma trt $=\left\langle\operatorname{tobd}_{b}, \operatorname{tobd}_{2}\right\}^{+}$, tobd $\mathrm{mr}_{\mathrm{b}} \mathrm{mr} \mathrm{r}_{2}>$, onde estāo determinados os tipos de objetos que podem fazer parte de cada divisão num relacionamento triplo. Num relacionamento triplo, a Divisāo1 e a Divisão3 deverão ter sempre um objeto, enquanto a Divisão2 poderá ter um ou mais objetos nāo necessariamente do mesmo tipo. As modalidades de relacionamentos $\mathrm{mr}_{1}$ e $\mathrm{mr}_{2}$ são respectivamente denominadas de modalidade de relacionamento de conjunto e modalidade de relacionamento de determinação. Todo relacionamento triplo pode ser projetado em um relacionamento binário de modalidade $\mathrm{mr}_{2}$ e um ou mais relacionamentos binários de modalidade $\mathrm{mr}_{1}$, como ilustra a figura 4.2.

\section{2 .3 - Atributos.}

Tanto objetos como relacionamentos possuem Atributos. As abstrações de atributos denominam-se tipos de atributos, que são definidos por uma tupla da forma ta $=\langle$ idatr,cta,tda $\rangle$, onde idatr é o designador do tipo de atributo, cta é a 
característica desse tipo de atributo, e tda é o seu tipo de dado, podendo ser um inteiro, real, byte, cadeia de caracteres, etc. Todo atributo segue o padrão definido no esquema da aplicação para seu tipo de atributo. A característica de um atributo de um determinado tipo delimita o conjunto de operações que um Gerenciador de Dados pode suportar. As características de Tipo de Atributo mais comuns a um Sistema de Gerenciamento de Dados para Engenharia que um gerenciador apoiado no MRO pode suportar são as seguintes:

-Sinônimo. Corresponde aos identificadores alternativos dos objetos, quando estes possuem dois ou mais identificadores. Atributos desse tipo somente podem ser associados a objetos.

-Comentário. Corresponde a informações para o usuário, que não sāo analisadas pelo sistema, tratadas apenas de forma textual;

-Regra. São atributos que possuem uma condição de disparo e uma ação. A condição permite que a ação seja executada sempre que for feita alguma operação sobre o objeto, tal como consulta ou atualizaçāo, ou quando for recebida alguma mensagem pelo objeto, oriunda da execução de outra ação ou procedimento na base de dados;

-Procedimento. São atividades que devem ser exercidas de uma forma pré-determinada pelo sistema, solicitadas pelos aplicativos, para execuçāo imediata ou postergada;

-Tempo. Indicação de tempo, absoluto ou relativo, atribuído aos objetos e relacionamentos. Permite que se registre o tempo absoluto de operações na base, ou o tempo do mundo real (ou de validade) definido externamente à base;

-Estrutura. São agrupamentos de informações com um significado completo que normalmente são representados em estruturas de arranjos de dados (vetores e matrizes), ou para as quais possam ser definidas operaçōes próprias de conjuntos, tais como uniāo e interseç̧ão, ordenação e tratamento de repetiçāo de valores (listas, filas, pilhas e montes);

-Gráfico. Corresponde à informação de localizaçāo no espaço, podendo indicar um 
ponto, uma função, um conjunto de segmentos de retas, uma operação de transformação, ou qualquer combinação destes;

-Imagens. São atributos que representam figuras, definidas através de valores associados a coordenadas cartesianas (pixels, raster, quad-tree,etc);

-Visualização. São atributos que podem definir como um elemento de um modelo pode ser visualizado em uma interface de entrada e saída do sistema, para permitir a interação de uma pessoa com um aplicativo que manipule o objeto ou relacionamento ao qual o atributo está agregado.

-Propriedade. Atributos que não tenham alguma característica especial que os distingua dos demais serão considerados tipos de atributos com característica de Propriedade: são atributos "comuns" dos objetos ou relacionamentos aos quais estão associados. Por simplicidade, "atributo com característica de alguma coisa" podem ser referenciados apenas como "alguma coisa". Por exemplo, atributos com características de propriedade podem ser referenciados apenas como propriedade.

Para tornar a modelagem mais natural, um conjunto de elementos de modelagem mantém na base de dados relacionamentos e atributos que nāo precisam ser explicitados pelo usuário. Tais relacionamentos e atributos são ditos intrínsicos. Um exemplo é a informaçāo de qual usuário é responsável pela criação de um objeto.

Atributos são essencialmente objetos cuja existência e comportamento são reconhecidos a priori pelo modelo. Esse tratamento apresenta duas vantagens: facilita a construçāo de um gerenciador, aumentando-lhe a eficiência; e torna o processo de modelagem de um sistema real mais intuitivo. As mesmas duas razões aplicam-se ao conceito de relacionamento definido pelo usuário: um relacionamento pode ser representado como um objeto que possui dois atributos: origem e destino, cujos valores são respectivamente os objetos origem e destino do relacionamento. Porém objetos assim possuem um significado que pode ser compreendido pelo gerenciador, e portanto facilita seu desenvolvimento e aumentam a eficiência de utilização do conceito.

Os atributos são aplicados a objetos ou a relacionamentos, sendo assim caracterizados como Atributos de Objetos ou Atributos de Relacionamentos. 


\subsection{4 - Col6́nias de Objetos.}

O recurso denominado Colônias de Objetos concentra diversos aspectos de modelagem, entre os quais a restrição do escopo de um identificador de um objeto, o estabelecimento de um relacionamento intrínsico de composiçāo entre objetos da base de dados.

Quando visto de maneira global, um sistema apresenta um pequeno grau de detalhe. Quando o interesse recai em um de seus componentes, o grau de detalhe desse componente aumenta. Uma ferramenta de comunicação com o usuário irá interpretar um identificador levando em consideraçāo somente o conjunto de informaçōes que está sendo examinado, e exigindo que qualquer referência a outras informaçōes tenha um teor de identificação maior.

Em termos de acesso a objetos, isso corresponde a se ter poucos objetos acessíveis enquanto se manipula a base de um ponto de vista global. Indicando ao sistema que pretende-se considerar um desses objetos, indica-se um grupo de objetos do qual pretende-se obter ou manipular informaçōes. Assim tornam-se disponíveis novos objetos. Esse procedimento pode ser repetido, indicando-se para consideração um dos novos objetos tornados disponíveis, o que aumenta sucessivamente o nível de detalhe, e correspondentemente a quantidade de objetos a que se tem acesso imediatamente, através de seus Nomes ou Sinônimos. Com o refinamento de um determinado aspecto, os demais não deixam de estar acessíveis, mas não sāo por sua vez refinados.

O MRO conta com essa capacidade devido aos conceitos de Colônia de Objetos, Objeto Considerado, Objetos Habitantes de uma Colônia, e Contexto.

$O$ acesso é imediato quando se procura um objeto através de seu código, pois este é único em toda base de dados. Porém pode existir mais de um objeto do mesmo tipo com um mesmo identificador. Para identificar um objeto univocamente pelo seu nome, é necessário especificar o Contexto onde ele está definido. O conceito de contexto corresponde a uma partição dos identificadores existentes na base de dados em Colónias de Objetos, de maneira que um nome esteja definido somente no domínio de uma Colônia.

Cada Colonia é constituída por um conjunto de objetos, e se refere a um determinado aspecto de interesse. Os objetos que pertencem a uma colônia são chamados habitantes dessa colônia. Cada objeto habita exatamente uma colônia. Por exemplo, numa Base de Dados para armazenar informaçōes Geográficas, tem-se a 
princípio a informação de quais países e continentes existem. Quando leva-se em consideração mais detalhes de um País, não aumentam correspondentemente os detalhes dos Acidentes Geográficos do Continente onde situa-se esse País, mas tão somente os detalhes do próprio País (por exemplo, seus estados). Se desejado, o usuário pode aumentar o nível de detalhe de um Acidente Geográfico de sua escolha, identificando-o para consideraçāo. Assim este terá os detalhes de um país e os de um Acidente Geográfico simultaneamente, mas sempre apenas um de cada.

Esse conceito estabelece também uma partição no conjunto de Tipos de Objetos, sendo cada partição denominada Tipo de Colônia. Cada Tipo de Colônia determina um conjunto de tipo de objetos. Assim objetos de um dado tipo somente podem habitar colônias de um único tipo.

Os objetos que habitam uma colônia tornam-se disponíveis quando a colônia é aberta para acesso. Das várias instâncias de colônias de cada tipo que podem existir, apenas uma pode estar aberta num dado instante. Uma das colônias terá que estar permanentemente disponível, e será denominada Colônia Global. Os objetos da Colónia Global são os que estāo disponíveis quando se está no nível menos detalhado de acesso ao sistema, e permanecem sempre disponíveis. Correspondentemente existe um Tipo de Colônia Global, o qual contém os tipos de objetos que existem na Colônia Global. Dessa forma, todos os objetos de tipos que pertencem à Colônia Global estarão permanentemente disponíveis. Numa base de informaçōes geográficas todos os objetos de tipo País, Acidente Geográfico e Continente pertencem à colônia global e sempre ficam disponíveis. Deve-se notar que, a menos da colônia global, que é única, qualquer outro tipo de colônia pode ter qualquer número de instâncias.

O conceito de colônia é distinto do conceito de classes de objetos: enquanto uma classe corresponde a todos os objetos de um mesmo tipo, uma colônia inclui objetos de diversos tipos diferentes, e (a menos da colônia global) não exaure o conjunto dos objetos de cada um dos tipos que a habitam.

Os tipos de colônias organizam-se segundo uma hierarquia, em que a colônia global é o topo da hierarquia, o nível imediatamente subordinado é constituído pelas colônias constritas por objetos de tipos que habitam a colônia global, e assim sucessivamente. Essa hierarquia ocorre devido à existência de um relacionamento intrínseco de composição entre o objeto que constringe a colônia e os objetos que a habitam.

Para sintetizar os conceitos apresentados até agora, a figura 4.3 mostra um 
Diagrama de Representaçao de Objetos com o sụbconjunto do Meta-Esquema do MRO, onde todos os seus conceitos săo apresentados graficamente.

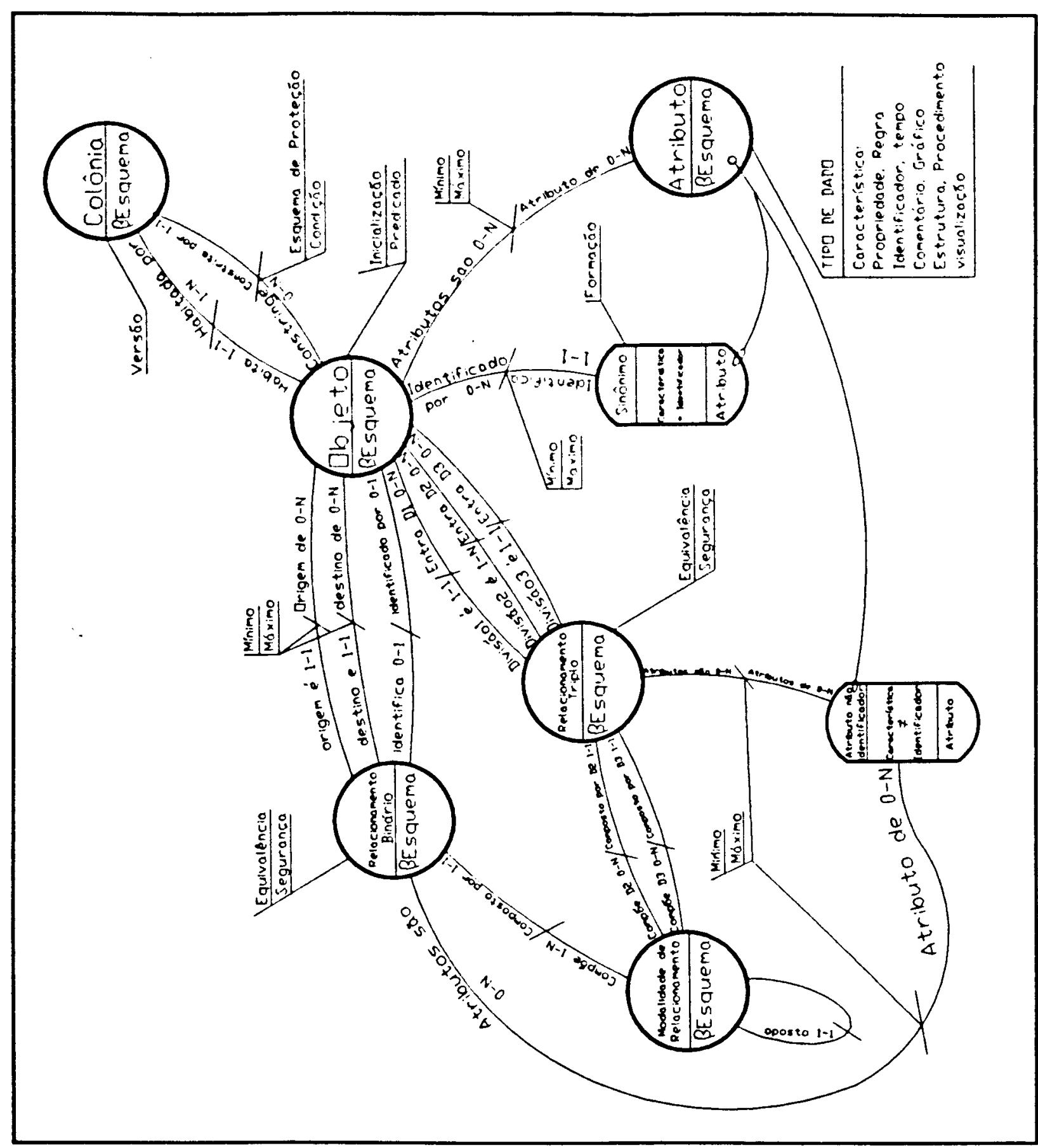

Fig.4.3: Subconjunto do Meta-esquema MRO. 
4.2.5 - Exemplo de Modelagem do MRO Utilizando o Experimento de Resfriamento de Átomos.

\subsubsection{1 - Descrição do Experimento.}

Inicialmente considera-se uma esfera com um determinado volume, onde aprisionam-se átomos com a distribuição inicial de velocidades conhecida. Esta esfera possui uma barreira de potencial, com altura e largura previamente definidas, na qual os átomos inicialmente não conseguem ultrapassar.

O Experimento tem como objetivo descrever a evolução da posição e a distribuição de velocidades dos átomos quando as características da barreira de potencial são alteradas. Estas características, se resumem na especificação da altura final e a velocidade de variação da barreira até atingir a referida altura final. Como a altura final, para este experimento, sempre é menor que a inicial, alguns átomos conseguirão ultrapassar a barreira, diminuindo assim nāo só o número de átomos no interior da esfera como também a temperatura, que é uma medida macroscópica da distribuição de velocidades.

Os dados importantes deste experimento são:

- Volume da esfera.

- Distribuição de Velocidades; vetor de ordem $n$, onde $n=$ números de átomos e cada elemento é uma estrutura que descreve as componentes de velocidade $V x, V y, V z$

- Posiçāo de cada átomo; vetor de ordem $n$, onde $n=$ múmeros de átomos e cada elemento é uma estrutura que descreve as componentes tridimensionais.

- Números de átomos iniciais aprisionados na esfera

- Energia Cinética e Temperatura ao longo do tempo.

- Altura e Largura inicial da barreira de potencial.

- Altura final e Velocidade de variação da barreira.

- Número de átomos aprisionados na esfera ao longo do tempo.

Para sintetizar os resultados deste experimento utilizam-se dois gráficos:

- Número de átomos em cada instante, obtido com a avaliação do vetor de Posiçāo.

- Temperatura em cada instante, obtida através do vetor de Distribuição de Velocidades.

A figura 4.4 ilustra o experimento descrito anteriormente.

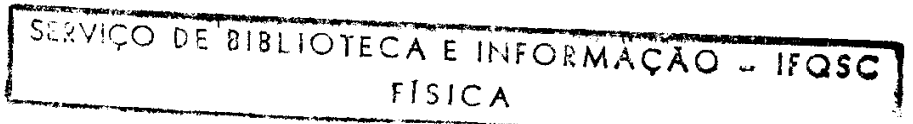




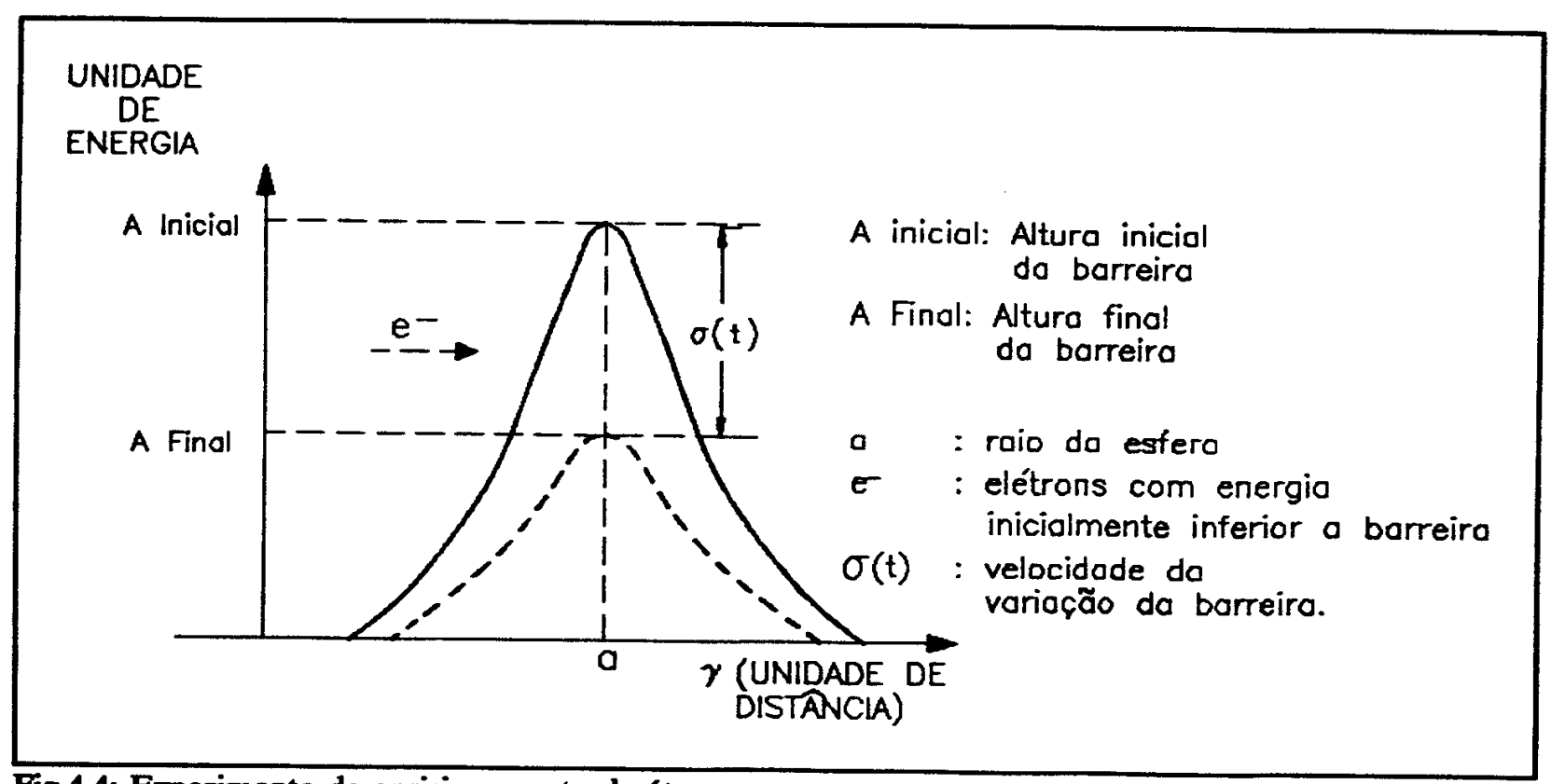

Fig.4.4: Experimento de aprisionamento de átomos.

\subsubsection{2 - Modelando o Experimento segundo o MRO.}

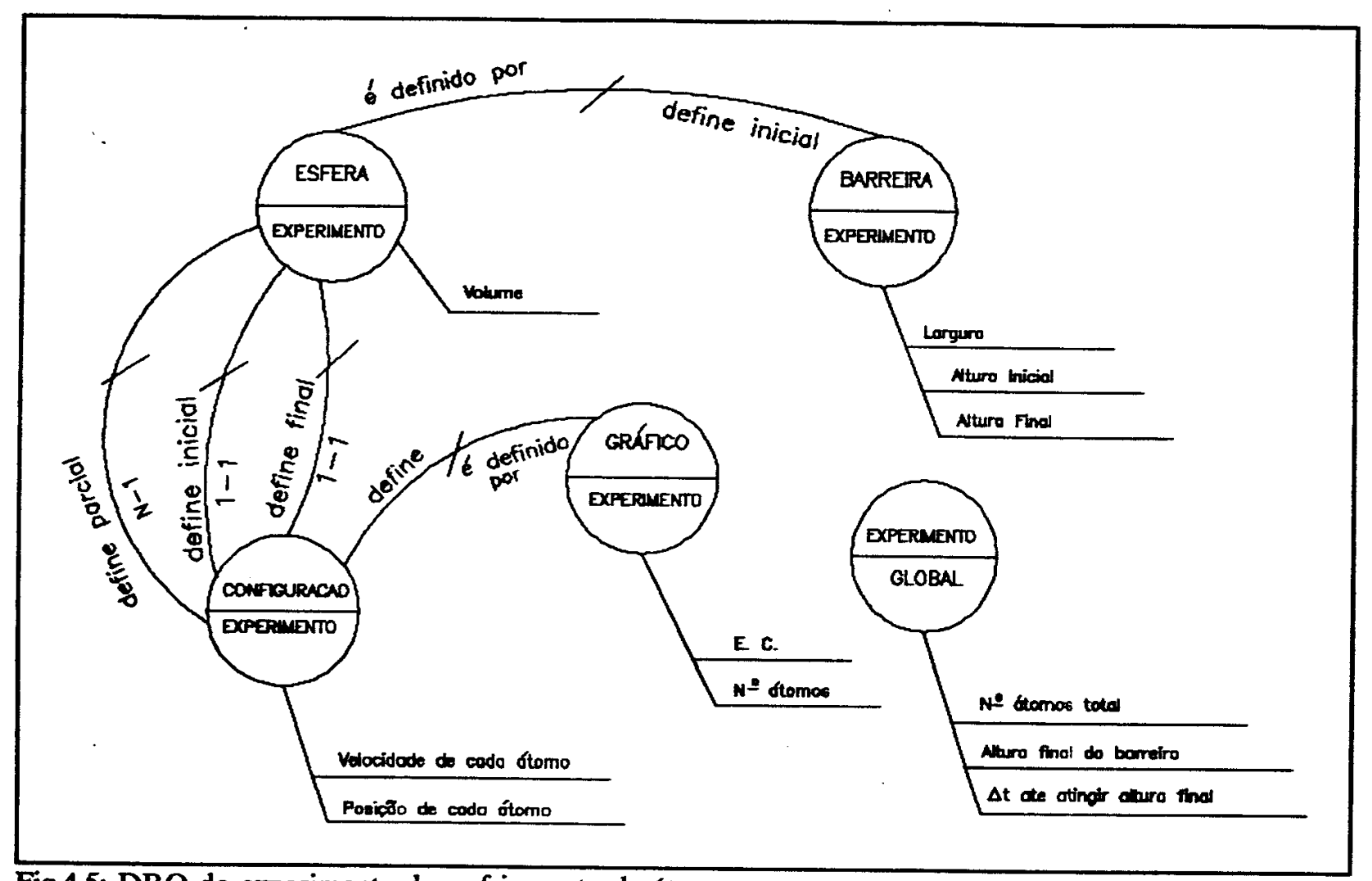

Fig.4.5: DRO do experimento de resfriamento de átomos.

A figura 4.5 apresenta a modelagem do experimento segundo o MRO. Nessa 
modelagem os conceito de relacionamento binário é utilizado para representar as relações entre esfera e barreira, configuração e gráfico. A colônia Global apenas reconhece os experimentos.

Utilizando ainda o Experimento podemos ilustrar o conceito de relacionamento

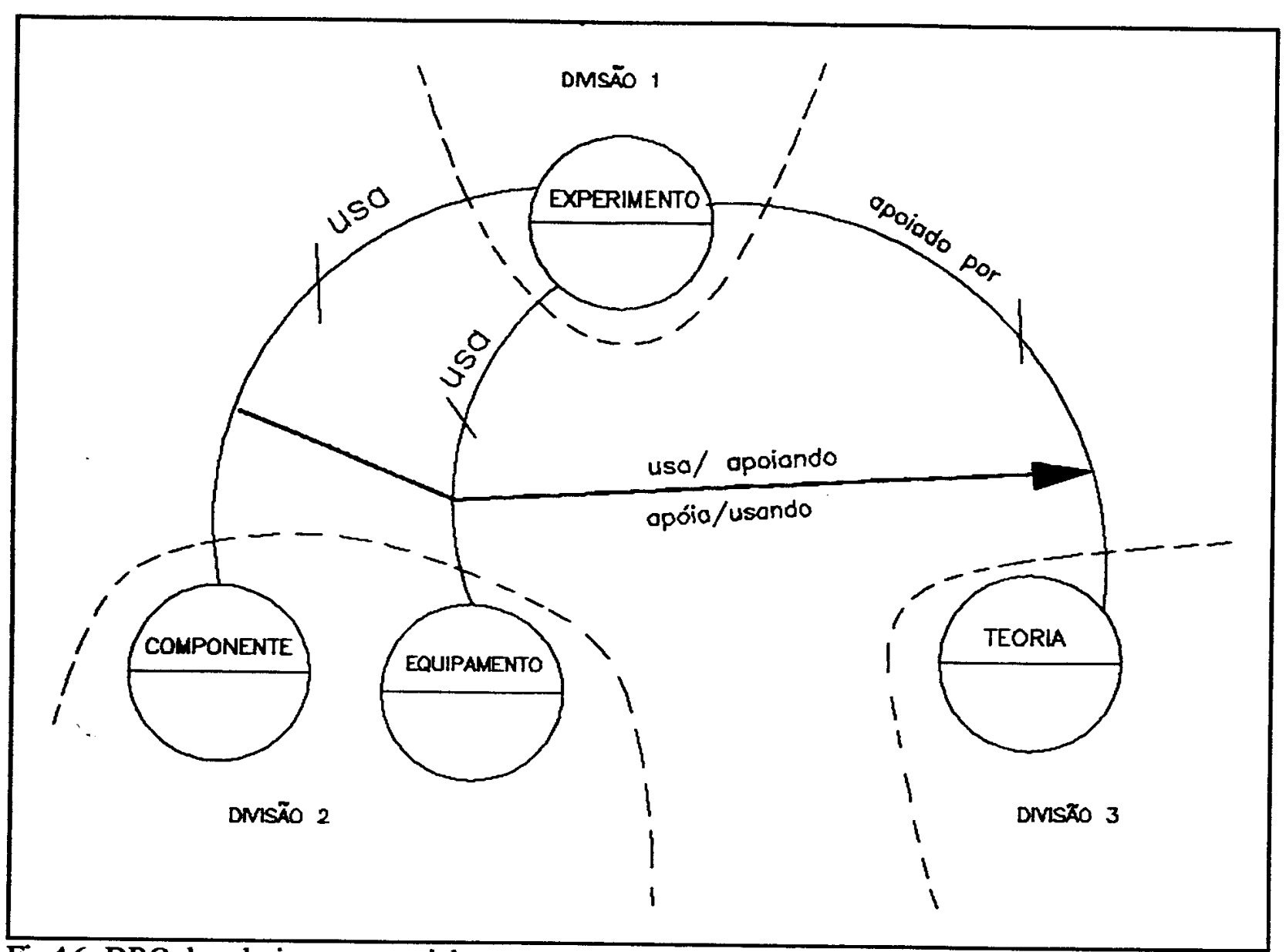

Fig.4.6: DRO do relacionamento triplo.

triplo, explicitando o relacionamento entre: Experimento, Teoria, Componentes e Equipamentos, conforme a figura 4.6, onde representa-se o fato de um experimento apoiar-se numa teoria, e utilizar componentes e equipamentos para ser realizado. As linhas tracejadas especificam as divisōes envolvidas no relacionamento triplo. Nesta figura fica mais evidente que um relacionamento triplo pode ser composto por relacionamentos binários. Pode-se observar também que o relacionamento entre a divisão 1 e 3 possui um atributo especial que tem como objetivo estabelecer o relacionamento da divisão 1-3 para com a divisão 1-2. 
4.2.6 - Relacionametos de Generalização e Sumarizaçāo.

Tipos de Objetos e Tipos de Relacionamenios podem ser especializados em Subtipos de Objetos e Subtipos de Relacionamentos. Subtipos sāo mantidos através de relacionamentos de generalização intrínsecos. Um Subtipo de objeto corresponde a uma tupla da forma:

stob $\left.=\left\langle t o b_{1}, \text { pred }\left(t a_{b}, . ., t a_{n p} t r_{1}, . t r_{m}\right),\left\{<t a_{j} v_{\text {valor }}\right\rangle\right\}^{+}\right\rangle$, onde:

$t^{t o} b_{i}$, corresponde à indicação de um tipo ou subtipo anteriormente definido chamado Tipo Mestre;

pred, é um Predicado calculado sobre os atributos e relacionamentos do objeto/relacionamento, que estabelece o critério de escolha dos elementos do tipo mestre, que constituirão o subconjunto de elementos daquele subtipo;

$\left\{<t a\right.$, valor $\left.\left._{j}\right\rangle\right\}^{+}$é um conjunto de valores de atributos e de relacionamentos padrões que devem ser usados para inicializar os valores ainda não definidos, quando É criado um objeto/relacionameto desse subtipo.

Alguns objetos podem ser semanticamente agrupados com outros, e coletivamente se caracterizam como supertipos. Assim, subtipos representam um mecanismo para a representação de relacionamentos de especialização, ao passo que supertipos correspondem à existência de relacionamentos de sumarização entre objetos. Um subtipo representa uma especializaçāo do objeto mestre, sem que isso represente a existência de um novo objeto; ao passo que um supertipo constitui um novo objeto que sumariza coletivamente os objetos a que se refere. Todos os objetos que pertencem a um conjunto de objetos que formam um supertipo devem necessariamente ser de tipos que habitam colônias de objetos de um único tipo. Tanto tipos de objetos quanto tipos de relacionamentos possuem subtipos, porém apenas tipos de objetos possuem supertipos. Da mesma maneira que os objetos, os tipos de relacionamentos também podem ter subtipos, os quais são caracterizados pelos atributos de seus tipos de relacionamento mestres.

\subsection{7 - Gerenciamento de Colónias.}

\subsubsection{1 - Acesso.}

As diversas perspectivas dos usuários são contempladas por um SGDE que adote 
o MRO, implementando-se o esquema de proteção e/ou ocultamento de informaçōes através do controle de acesso às Colônias de Objetos [TRAINA_91b]. O acesso a Colónias de Objetos pode ser controlado, permitindo-se abrí-la para consulta ou atualização. Para obter acesso aos dados de interesse, os programas de aplicação precisam informar quais colónias devem ser abertas e quando devem ser fechadas.

Com a proteção atuando a nível de colônias, aquelas alocadas para um determinado usuário estarão protegidas do acesso para qualquer outro usuário, ao mesmo tempo em que este nāo poderá acessar uma área de interesse de outro usuário.

Em operaçōes normais, qualquer usuário tem acesso para leitura na colônia global, e através da indicaçāo sucessiva de vários objetos para consideração, várias colónias tornam-se acessíveis. Na base de dados de um projeto já adiantado, envolvendo vários usuários, a colônia global já deverá estar definida e razoavelmente estática, quando então, qualquer usuário poderá ter acesso a ela apenas para consulta, permitindo que outros usuários a compartilhem para leitura. Apenas nas colónias em nível hierárquico inferior um usuário obterá permissão individual para escrita. A atualização da colônia global será permitida apenas a usuários privilegiados, tal como o gerente de projeto, o qual para atualizá-la, deverá requerer que naquele instante, ninguém mais tenha acesso à qualquer parte da Base de Dados.

\subsubsection{2 - Versōes.}

Os sistemas de apoio a projetos devem suportar a existência de máltiplas versōes tanto do projeto todo, quanto de qualquer parte dele [KELTER_87]. Katz [KATZ_86] caracteriza "Versão" e "Alternativa", considerando que um projeto está inicialmente em progresso, e que sobre ele os projetistas efetuam mudanças e incorporação de dados. As alterações feitas para experimentar outras formas de implementação são Alternativas, e aquelas que são aprovadas para fazer parte do produto final são chamadas Versōes. Um projeto pode ter muitas versões e muitas alternativas, sendo que as versões produzidas são armazenadas na base de dados para sempre.

O MRO suporta a armazenagem das várias versōes e alternativas de um projeto, permitindo a geração de Instâncias de Colônias de Objetos, de maneira que uma colônia constrita por um objeto pode ter várias versões e alternativas. Cada instância é chamada de uma Variante, e corresponde ou a uma Versão ou uma Alternativa. Cada instância terá atributos de acesso e proteçāo independente das demais instâncias da 
mesma colónia, e poderá ser acessada por um usuário de maneira independente dos demais.

Se alguma alteraçāo for necessária, então deve ser criada uma nova alternativa que, essa sim pode ser modificada. Em termos de operaçōes na base de dados, isso corresponde à instanciação da colônia, criando-se duas instâncias para a referida colônia. A que corresponde à versão original permanecerá protegida contra escrita, e a outra, que corresponde a nova alternativa criada (inicialmente idêntica à versão original) fica liberada para alterações, sendo entāo editada. Se a alteraçāo eventualmente levar a uma nova versão, ela será, por sua vez e a seu tempo, também congelada e protegida contra escrita.

Cada usuário pode ter apenas uma das instâncias de cada colônia disponível num dado instante, a qual é chamada de Variante Corrente da Colônia.

\subsubsection{3 - Esquema.}

Sendo armazenado em uma Colônia de Objetos, o esquema de uma aplicaçāo está sujeito as mesmas regras de operaçōes que governam as demais colônias. Isso vale também para os critérios de instanciaçāo de colônias, o que significa que podem existir várias versōes de esquemas. No entanto, uma colônia esquema é reconhecida pelo SGDE e tratada de maneira especial quando as operaçōes se referem a colônias esquematizadas por ela. Portanto, para que um esquema de dados possa ser usado como tal, é necessário que a sua Colónia Esquema esteja protegida contra escrita, ou seja, somente podem ser usadas variantes que sejam versōes.

Assim, para que uma base de dados possa ser usada, ela deve ser inicializada, e sua Colônia "Global" e Colônia " $\beta$ Esquema" criadas. A Colônia "Global" passará a ter inicialmente um único objeto que constringe a Colônia " $\beta$ Esquema", na qual o esquema da aplicação deve ser definido. Uma vez concluído o esquema, ele deve ser "Congelado", para permitir o início da utilização da base de dados.

Se alguma alteraçāo for necessária, a colônia " $\beta$ Esquema" deve ser instanciada, e a nova alternativa para o esquema deve ser fornecida ao sistema. No entanto, para que possa proporcionar o acesso à base de dados, a nova alternativa terá que se tonar uma versão e portanto congelada. Nesta situaçāo, existirão duas versōes para uma colônia esquema de uma base de dados. Será usada para um determinado projetista a versão que corresponde à sua variante corrente. 
A cada instante, existe apenas um Esquema Corrente, sendo apenas através dele que a base de dados pode ser manipulada pelo usuário. Além disso, cada colónia está definida sobre um determinado esquema, que estava corrente quando a colónia foi criada ou instanciada.

Note-se que, dessa maneira, alterações no esquema de uma aplicaçāo não causam impactos na estrutura da base de dados, uma vez que as informaçōes em uma colônia da base, estarāo sempre ligadas à versão do esquema que criou a alternativa da colônia, a qual estará sempre disponível.

\section{3 - O Gerenciador de Objetos (GEO).}

\subsection{1 - GEO Mono-nsuário.}

O Sistema Gerenciador da Base de Dados do MRO (GEO) foi dividido a nível de implementaçāo em cinco módulos:

1) Nácleo de Acesso a Registros, o qual emula um sistema de gerenciamento de arquivos lógicos, e que suporta os demais módulos. Engloba o Subsistema de Gerenciamento de Registros - SGR, Subsistema de Gerenciamento de Arquivos - SGA, e Subsistema de Gerenciamento de Memória. Este último suporta todo o gerenciamento de memória secundária, emula uma memória "cache" para disco em memória, e efetua todo o controle de acesso e proteção dos dados, através do gerenciamento de transações.

2) Subsistema Básico de Gerenciamento de Objetos, o qual permite a manipulação de objetos sem restrições de ordem semântica. Envolve o tratamento de Identificadores de objetos, tratamento de relacionamentos de composição de objetos, contexto e navegação de objetos na base.

3) Subsistema Básico de Gerenciamento de Relacionamentos, o qual permite a manipulação de relacionamentos definidos pelo usuário entre objetos, tanto binários quanto triplos.

4) Subsistema Básico de Gerenciamento de Atributos, o qual permite atualmente a manipulação de atributos com características de Propriedades e Comentários, tanto para objetos quanto para as duas formas de relacionamentos, e com característica de sinônimo para objetos. 
5) Gerenciador de Esquemas de Dados, o qual consiste no Editor de Esquemas de Dados,(Geógrafo) e nas Primitivas de Acesso ao Esquema de Dados, que permite a edição do esquema da aplicação interativamente, através da definiçāo dos tipos de objetos, relacionamentos, identificadores, etc., e respectivas associações que a aplicação suporta.

Os quatro últimos módulos são construídos cada um em dois níveis de abstração: nível Básico e nível Semântico.

O conjunto dos quatro submódulos dos Subsistemas de Gerenciamento Básico é denominado GEO/MRO-Básico, e o conjunto de quatro submodulos dos Subsistema de Gerenciamento Semântico é denominado GEO/MRO-Semântico. Qualquer Subsistema do GEO/MRO-Semântico utiliza todo o GEO/MRO-Básico, e não apenas seu correspondente básico.

O GEO/MRO-Básico efetua todas as operaçōes de acesso efetivo na base de dados, tal como criar ou eliminar objetos, relacionametos, etc. O GEO/MRO-Semântico deverá realizar as mesmas operações, porém avaliando não apenas as regras sintáticas estáticas tal como é feito agora pelo GEO/MRO-Básico, mas também as regras semânticas que dependem do ambiente instantâneo dos dados na base. A figura 4.7 apresenta a estrutura geral do GEO. Pode-se observar que o Ge6grafo é considerado um utilitário do sistema, nāo pertencendo ao núcleo do GEO propriamente dito.

\begin{tabular}{|c|c|c|c|}
\hline \multicolumn{3}{|c|}{ Aplicativos } \\
\hline Geógrafo & Ed. de consultas & Ap. específicos & $\ldots .$. \\
\hline \multicolumn{3}{|c|}{ MRO-Semântico } \\
\hline \multicolumn{3}{|c|}{ MRO-Básico } \\
\hline \multicolumn{2}{|c|}{ Núcleo } \\
\hline SGR-Fixos & SGR-Variáveis \\
\hline SGA-Registros Fixos & SGA-Registros Variáveis \\
\hline \multicolumn{2}{|c|}{ Sub-Sistema de Gerenciamento de Memória } \\
\hline \multicolumn{2}{|c|}{ Sistema Operacional } \\
\hline
\end{tabular}

Fig.4.7: Núcleo do gerenciador de objetos.

O GEO foi especificado para suportar dois tipos de interfaces de consulta: programacional, como um conjunto de rotinas chamáveis em "C"; e a interpretada, com 
acesso navegacional, priorizando o acesso individualizado aos objetos, com uma extensão que permite o acesso coletivo aos objetos através de "Seleçōes de Objetos" [PIZZIGATTI_90].

Existem duas versōes disponíveis do GEO: uma mono-usuária, desenvolvida em micro-computadores compatíveis com IBM-PC/XT (DOS) e outra multi-usuária, desenvolvida nas estações de trabalho SUN SparcStation (UNIX).

\subsection{2 - Sistema de Gerenciamento de Mem6ria(SGM) Mono-usuário.}

O SGM mono-usuário utiliza um sistema de memoria "cache" para acesso a disco, onde cada registro desta memória tem tamanho, em bytes, exatamente igual ao tamanho de um bloco de dados manipulado pelo sistema de gerenciamento de arquivo do sistema operacional. Para controle da memória "cache" o SGM utiliza uma técnica que permite detectar, entre os registros residentes no "cache", quais os menos utilizados. Através deste critério, o SGM elege qual registro deve sair da memória "cache" para deixar disponível o espaço para entrada de um registro localizado em disco. Associada a estrutura "cache", existe uma estrutura de dados que controla o tipo de acesso (leitura ou escrita) efetuado sobre as páginas do "cache".

O diagrama hierárquico das funçōes do SGM-GEO mono-usuário, apresenta duas primitivas de acesso à base, uma para leitura e outra para escrita. O SGM atrasa a escrita na Base de Dados com objetivo de aumentar a eficiência. Sendo assim, a atualização (escrita) só será repassada para Base de Dados quando o SGM eleger tal registro para sair do "cache", gravando em uma única operação de acesso a disco todas as alteraçōes que foram efetuadas em "cache".

\subsection{3 - GEO Multi-usuário.}

A versão multi-usuário foi desenvolvida [CALÔNEGO_91] tomando como base a versão mono-usuário onde foram alterados os seguintes módulos lógicos, como mostram as figuras 4.10 e 4.11 :

\begin{tabular}{|c|c|c|}
\hline Nivel Semântico & $\begin{array}{c}\text { Manipulação de } \\
\text { Objetos Lógicos }\end{array}$ & $\begin{array}{c}\text { Gerenciador de } \\
\text { Objetos Físicos }\end{array}$ \\
\hline
\end{tabular}


Os objetivos principais da versão multi-usuário são:

- Garantir que a comunicação entre processos seja estabelecida através do Sistema Operacional, utilizando o modelo Cliente/Servidor;

- Através de um Sistema de Gerenciamento de Transações (SGT), garantir a atomicidade das transaçōes e estabelecer o protocolo de acesso aos itens de dados armazenados na base.

\begin{tabular}{|l|l|}
\hline \multicolumn{2}{|l|}{ Sistema de Comunicação entre Processos } \\
\hline Sistema de Gerenciamento de Transações \\
\hline & Nivel Semântico \\
\cline { 2 - 2 } & Manipulação Lógica de Objetos \\
\cline { 2 - 2 } & Sistema de Gerenciamento Memória \\
\cline { 2 - 2 } & Manipulação de Registros Físicos \\
\hline
\end{tabular}

Fig.4.9: Módulos Lógicos do GEO-Multi-usuário

Os processos se comunicam com os gerenciadores, de modo que vários processos concorrem, através do Sistema Operacional, pelo acesso a um gerenciador. As primitivas de manipulação da base de dados oriunda de um cliente passam por um processo de empacotamento transparente ao usuário, e são enviadas ao servidor através de primitivas de comunicação entre processos que são suportadas pelo Sistema Operacional.

A Estrutura Lógica do Sistema GEO multi-usuário pode ser representada através de um diagrama de fluxo de dados, figura 4.10, onde destacam-se três modulos:

1- Interfacear Base: conjunto de ferramentas que permitem ao Administrador da Base de Dados ter acesso às primitivas de controle do sistema.

2- Processar Ações: conjunto de primitivas que estabelecem as ações que os aplicativos dos projetistas podem solicitar. Tais solicitações são codificadas e transmitidas para o Gerenciador de Base de Dados.

3- Gerenciar Ações: conjunto de primitivas, que compõem o Sistema de Gerenciamento de Base de Dados, que é responsável pelo Gerenciamento de transaçōes, controle de concorrência, interface com os aplicativos, manipulação 
de objetos lógicos e gerenciamento de memória.

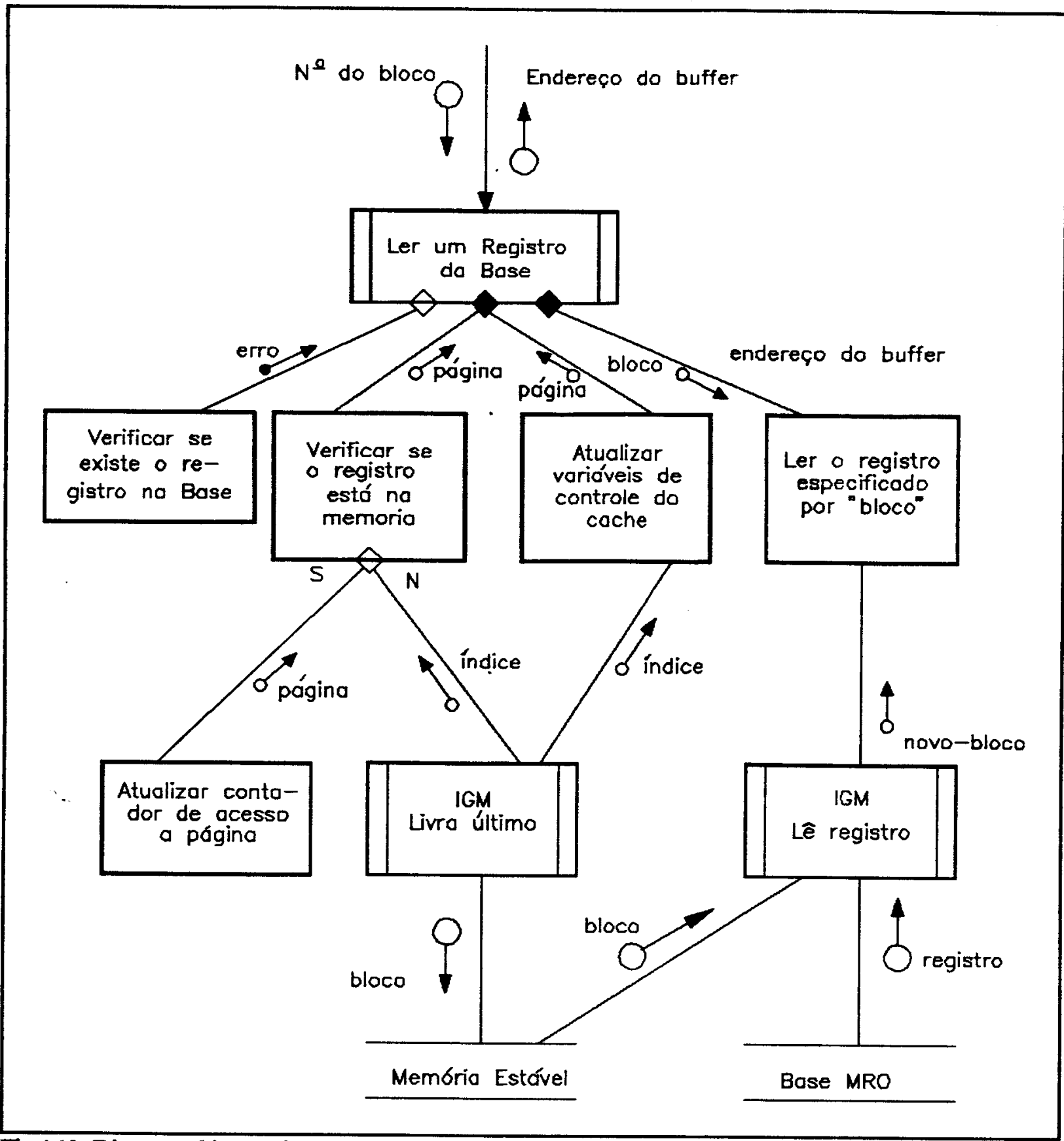

Fig.4.10: Diagrama hierárquico do SGM.

Os componentes Fila de Entrada e Fila de Saída, são os elos de comunicação entre os Aplicativos e os Gerenciadores. O componente memória Estável é um arquivo intermediário, utilizado para que se consiga garantir a atomicidade das transaçōes.

Os mecanismos de acesso aos registros físicos da Base de Dados sāo controlados através de três níveis:

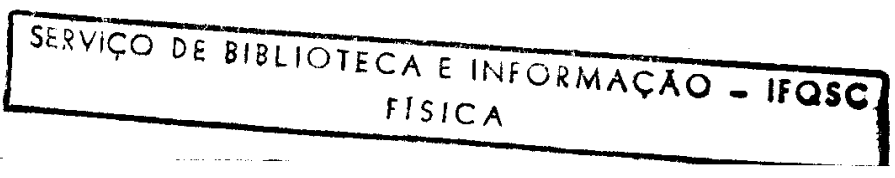


1- Nível Semântico: garante aos usuários acesso exclusivo às colônias, não significando entretanto acesso exclusivo aos objetos constritos por essa colónia.

2- Sistema de Gerenciamento de Transações SGT: verifica se a ação solicitada faz parte de alguma transação ativa no GEO.

3- Sistema de Gerenciamento de Memória SGM: verifica se as operações de leitura e escrita sobre o bloco podem ser efetuadas pela transação.

\subsection{4 - Sistema de Gerenciamento de Memoria Multi-usuário.}

Um SGM multi-usuário deve garantir não apenas que vários itens de dados possam ser acessados "simultaneamente" por diferentes transaçóes que manipulam a base de dados, mas também a atomicidade e consistência destas transações.

Conforme mostra o diagrama hierárquico da versão multi-usuário representado na figura 4.10, busca-se a atomicidade das transações na medida em que as informaçōes atualizadas por uma determinada transação são confirmadas somente quando a transaçāo for finalizada.

Dada as características das atualizações (escritas) no que se refere ao espaço de memória, o SGM multi-usuário apresenta uma memória expandida para o estouro do "cache" chamada de memória estável, onde os registros das transaçōes parcialmente compromissadas são armazenadas.

O SGT identifica as páginas do "cache" que estão sendo utilizados pelas transações, através de uma estrutura auxiliar conforme mostra a figura 4.11. Esta estrutura permite garantir o controle de concorrência confrontando-se o código da transação corrente com a página que se deseja alterar. Se o código da página coincidir com o

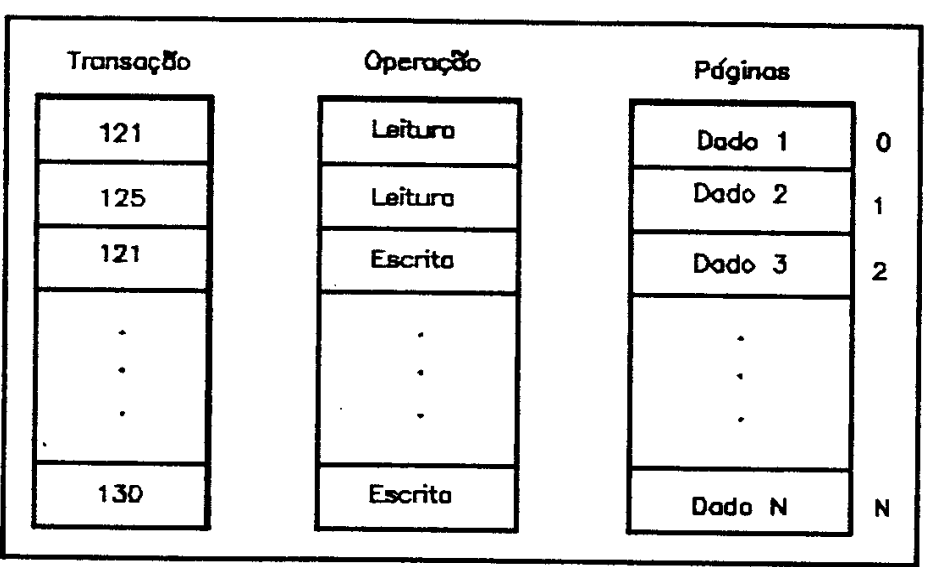

Fig.4.11: Sistema de controle de transação. código da transaçāo corrente associado à página, o SGM informará ao SGT que a transação é válida. Caso contrário, a transação será invalidada passando para um estado falho. 
4.3.5 - Sistema de Gerenciamento de Transação do GEO multi-usuário.

Para o SGT, cada ação é composta por três módulos lógicos. O primeiro, verifica se a ação pode ser executada; $O$ segundo, verifica se a ação não falhou e o terceiro é o corpo da açáo.

Os dois primeiros módulos têm a função de avaliar a validade da ação. A validação é realizada no SGT através de uma lista linear que armazena o estado de cada transação pendente no sistema (ativa ou falha). Esta estrutura de dados é chamada de MRO_BCT (Bloco de Controle de Transações para uma Base MRO).

Com isto, para um aplicativo realizar qualquer alteraçāo sobre a base de Dados é necessário "abrir" um registro de controle de transaçōes. Uma vez obtido o registro de controle de uma transação, o usuário fica associado a um valor lógico que é a sua identificação na Base. Uma outra primitiva é utilizada para inicializar uma transação, permitindo assim, $o$ acesso a Base.

Embora garanta o controle de concorrência do sistema, este mecanismo não impede que as açōes descritas em cada transação possam falhar na fase de execução. A informaçāo da situaçāo da açāo é armazenada no módulo lógico: "verifica se transação falhou". Para finalizar a transação o aplicativo deve executar uma primitiva, que tem a responsabilidade de informar ao SGT que a transação deve ser finalizada, e se não houver transaçōes pendentes, este encerrará o ambiente.

A descriçāo do SGT realizada até o momento, limitou-se a tratar a maneira pela qual diversos processos acessam um determinado gerenciador. Entretanto, para um ambiente multi-usuário é necessário que vários processos possam acessar vários gerenciadores. Existem primitivas que resolvem este problema, de modo a selecionar com qual gerenciador da transação local, o usuário deseja se comunicar, em um determinado instante.

A figura 4.12 sintetiza os aspectos importantes do GEO Multi-usuário apresentados. Nesta figura, tem-se o sistema de comunicação como gerenciador da interface entre os usuários e os gerenciadores, que por sua vez, acessam as respectivas bases MRO. Pode-se observar que em cada gerenciador existe um ambiente reservado para especificação dos usuários e no sistema de comunicação existe a informação de quais usuários estão utilizando os gerenciadores. 


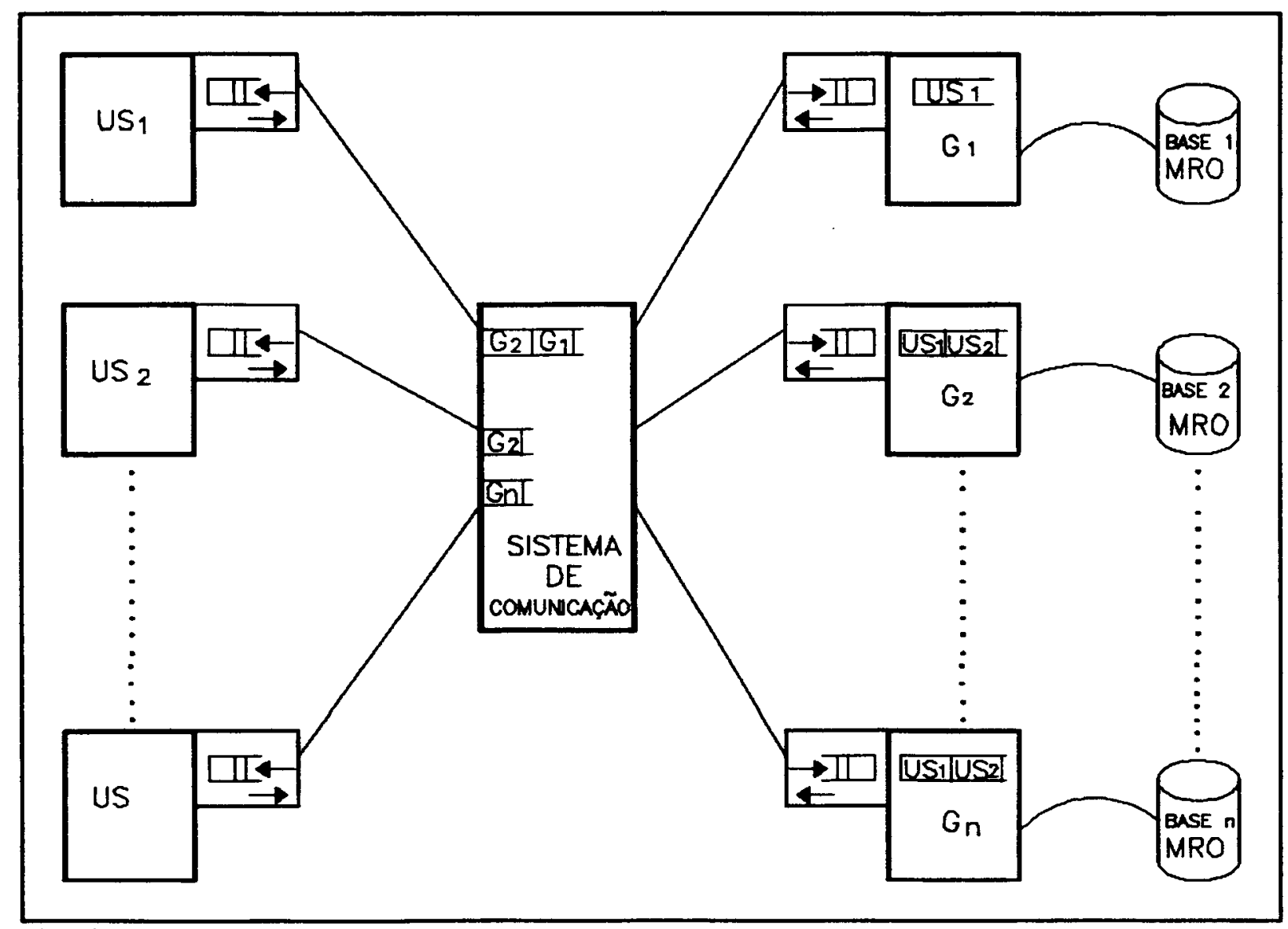

Fig-4.12: Sistema multi-usúrio MRO.

\section{4 - Conclusão.}

Apresenta-se como conclusão deste capítulo, uma situação de necessidade de alocação da Base de Dados apoiada no Modelo de Representação de Objetos para diversos nós localizados em uma Rede de Computadores.

Portanto coloca-se em questão como a Base de Dados MRO pode ser distribuída. Para tal distribuiçāo, cada conceito apresentado neste capítulo terá que ser analisado de modo a caracterizá-lo de acordo com a nova situação proposta. Colônias, objetos, relacionamentos, atributos, etc serão replicados ou particionados, totalmente ou não, de acordo com os critérios de autorização de operaçōes sobre a Base de Dados.

O Capítulo seguinte tratará deste problema, apresentando as possibilidades para a distribuição da Base de Dados, bem como um projeto funcional e lógico como uma possível soluçāo para o problema em questão. 


\section{Capítulo 5 \\ DISTRIBUIÇĀO DA BASE DE DADOS APOIADA NO MRO}

\section{1 - Introdução.}

A distribuição de Bases de Dados Convencionais apresenta como característica principal a disponibilidade dos dados, ao mesmo tempo, a todos os usuários. Assim os problemas de conflito causados pela concorrência para obtenção dos mesmos tornam-se muito acentuados.

Conseqüentemente, o desenvolvimento de um sistema que trate tal distribuição será especificado de modo a não permitir inconsistência dos dados. Para isso, são implementados algoritmos que buscam efetuar o escalonamento de transaçōes conflitantes, que operam sobre um conjunto de dados parcialmente ou totalmente comuns.

Esses algoritmos atendem tanto a uma situação de concorrência dos dados num ambiente multi-usuário centralizado como num ambiente distribuído. Ressalte-se no entanto, que as características de cada uma dessas situaçōes são diferenciadas, devido à natureza das transações envolvidas.

As transaçōes em um ambiente distribuído têm um tempo de transação normalmente grande. $O$ tratamento da concorrência dos dados, como descrito no capítulo 2, causa um grande "overhead" no Sistema de Base de Dados. Mas, como mencionado anteriormente, uma das necessidades que justifica a distribuição dos dados numa Base de Dados Convencional é a disponibilidade dos dados para todos os usuários concomitantemente. E é em favor deste recurso oferecido ao usuário que se incorporam os mecanismos de controle de concorrência num Sistema de Base de Dados 
Convencional (SBDC).

Além do problema de concorrência num SBDC, existe também o Controle de Integridade, que $\epsilon$ ainda mais acentuado num ambiente distribuído em decorrência da possibilidade de falhas, durante a comunicação entre os nós pertencentes a rede. Em decorrência disto, são desenvolvidas Estruturas Robustas, como descritas no capítulo 3, de modo a diminuir o efeito das falhas de comunicaçăo no sistema. Embora isto comprometa ainda mais a eficiência do Sistema, oferece aos usuários a existência "simultânea" e consistente dos dados.

A distribuição dos dados envolve o tratamento da concorrência, versão e partição [KIM_91], na medida em que ocorrem as mais variadas formas de c6pias dos dados. Neste trabalho, o controle de concorrência não é tratado, pois as necessidades que deverão ser atendidas não exigem tal tratamento.

Em Bases de Dados não convencionais, e mais especificamente no MRO, onde o ambiente de trabalho é essencialmente voltado para desenvolvimento de projetos, as necessidades de distribuição têm características distintas em relação às Bases de Dados Convencionais. Embora possam haver situaçōes em que o sistema deva incorporar o tratamento da concorrência dos dados, não se justifica o desenvolvimento deste recurso, face a baixa percentagem de relevância em relação a outras necessidades de distribuição. Cabe salientar que grande parte da concorrência de dados é tratada a nível semântico do modelo de dados, com a partição dos objetos em colônias.

As principais necessidades de distribuição que uma Base de Dados voltada para um ambiente de desenvolvimento de projetos deve atender são: 1)suportar transações longas, que levam possivelmente meses; 2)permitir que muitos projetistas participem de uma mesma tarefa dentro do projeto; 3)possibilitar que parte do trabalho seja de uso exclusivo de um determinado projetista e outras partes compartilhadas por outros projetistas; 4) possibilitar que a parte compartilhada, que em geral tem acesso permitido apenas para leitura, esporadicamente possa ser liberada para alteração; 5) permitir que a base suporte conflitos, considerando que estes são resolvidos externamente; 6) permitir ao projetista operar isoladamente na sua estação de trabalho com muito poucas intervençōes ou consultas à base "oficial" do projeto; 7) permitir a integração de um subprojeto, após sua conclusão, ao restante do ambiente de trabalho.

Para elaborar um projeto funcional e lógico de distribuiçāo de dados capaz de atender às estas necessidades, optou-se pela utilização de um modelo de representação de dados denominado Modelo de Representação de Objetos - MRO, que atende a um 
amplo espectro de aplicaçōes, incluindo aplicações integradas de projeto e produção de sistemas em geral [TRAINA_88].

Tal como seu nome indica, o Modelo de Representação de Objetos possui o enfoque de ser orientado a objetos e permite a representação de grande conteúdo semântico, adequado a sistemas de apoio à documentação e desenvolvimento de projetos, onde cada objeto de projeto tanto pode ser único, quanto podem existir conjuntos de dados semelhantes, tratados coletivamente. Além disso, o MRO permite a construção de Meta-Sistemas, em que a especificação dos requisitos da própria aplicação devam ser mantidos na mesma Base de Dados.

\section{2 - Conceitos Envolvidos na Distribuição do MRO.}

Em um ambiente de desenvolvimento de projetos apoiado numa base de dados não convencional, por exemplo no $\mathrm{MRO}$, as necessidades de distribuição são qualitativamente distintas da base de dados convencional. A concorrência dos dados passa de uma necessidade primordial para um recurso desejável para a base de dados.

$\mathrm{Na}$ distribuição de uma base de dados não convencional (MRO), um dos principais requisitos é a disponibilidade dos dados de forma que cada ítem(objeto) possua independência em relação à base original, podendo inclusive decidir qual o tipo de relacionamento que pretende estabelecer entre a cópia e a versão oficial. Isto corresponde a uma das classificações feita por Özsu em [ŌZSU_91], onde apresentam-se três tipos de alternativas para a arquitetura de Base de Dados Distribuídas. Diante disto, a cópia pode "evoluir" segundo as operações requisitadas pelo nó que a comporta e, depois de um determinado tempo, sofrer um processo de integração com a versão oficial [SINGHAL_90]. É também importante neste ambiente que o sistema permita a separação da própria cópia, possibilitando a geraçāo da distribuiçāo de vários níveis de cópias, de acordo com o solicitado pelo usuário.

Estes requisitos de distribuição [MARTIN_91] são necessários pois a Base de Dados apoiada no MRO pressupõe que, num ambiente de desenvolvimento de projetos, um determinado nó deverá conter as informaçōes gerais de um projeto que será dividido em subprojetos, os quais terão evoluçāo própria, e passado algum tempo poderão sofrer um processo de integração, que dependerá da semântica utilizada para a separação.

Ainda pode-se destacar a importância de um processo de integração mesmo que 


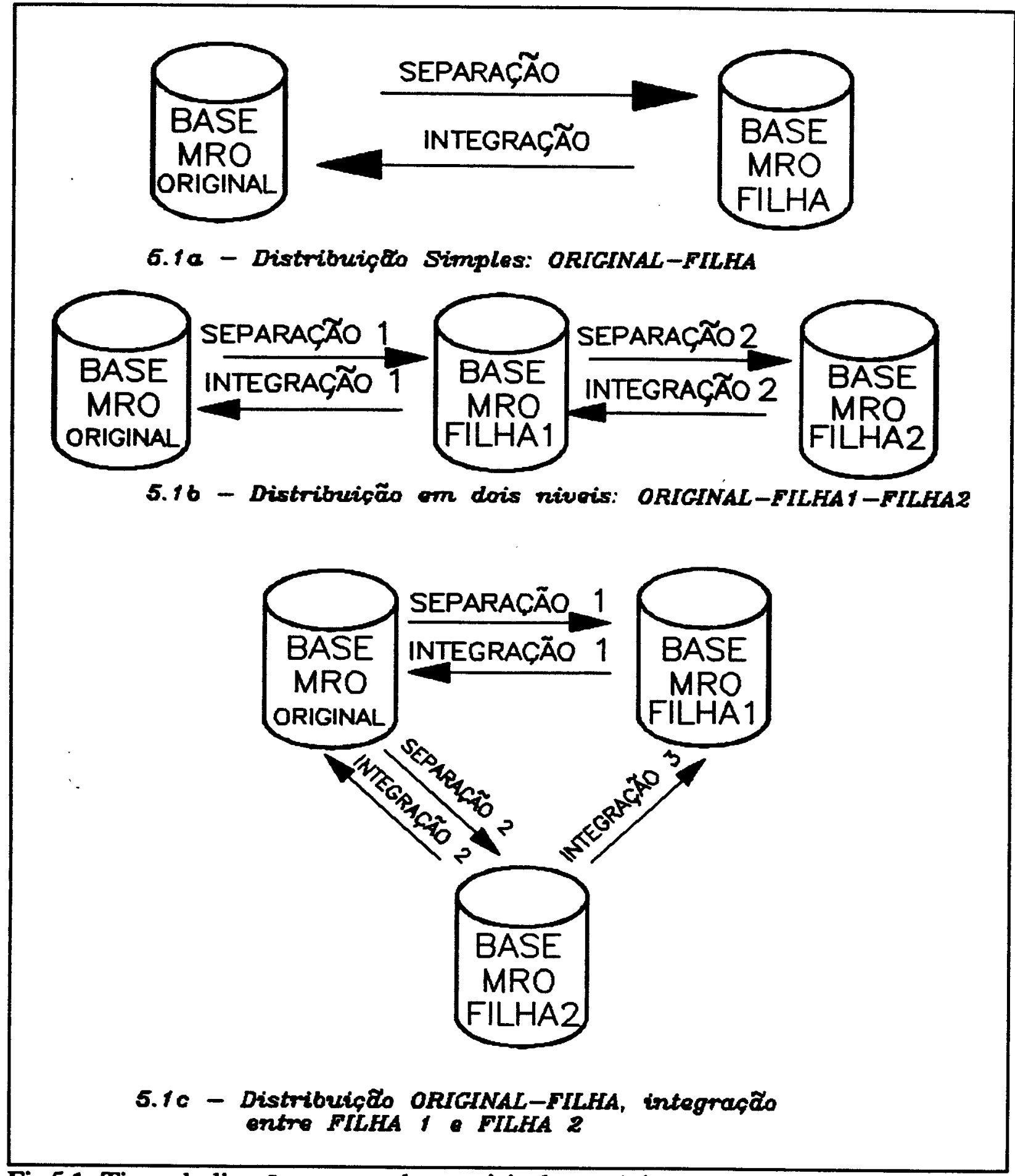

Fig.5.1: Tipos de ligaçōes entre a base original e a cópia.

as Bases de Dados não sofreram um processo de separação anterior. Isto equivale a dizer que projetos desenvolvidos de forma independente podem em determinada circunstância sofrer um processo de integração. Desse modo as formas de distribuição podem ser esquematizada como mostra a figura 5.1.

As formas de distribuição apresentadas na figura 5.1 sugerem a existência de tipos 
de ligações implícitos entre a versão original e a cópia. Além disso, a figura mostra que diferentes operaçōes de separação e integração podem ocorrer. A figura 5.1a mostra uma distribuição onde apenas existe uma base original e cópias diretas. A 5.1b apresenta dois níveis de distribuição, onde a base filha1 que na separação1 era cópia, na separação2 passa a ser base original, tendo como base cópia a filha2. Já a figura 5.1c apresenta duas separações de uma mesma base, entretanto ilustra uma integraçāo entre a base filha1 e filha2 que não estabeleceram um processo de separação. Tal integração tem algumas características diferentes da integração precedida de um processo de separação.

Note-se que o processo guarda semelhança também com as técnicas de desenvolvimento, de integração de esquemas múltiplos e bases de dados. No entanto, o tratamento do problema é feito neste trabalho apenas através de distribuição de bases de dados, devido ao fato de que existe sempre um único esquema original, o que elimina os problemas oriundos da análise de esquema(ou subesquemas) que têm origens distintas, tal como nas outras técnicas.

Em funçāo das características da distribuiçāo da Base de Dados, é possivel considerar os seguintes tipos de distribuição apresentados na figura 5.2.

Considerando os vários tipos de ligações possíveis entre a versão original e a copia para um ambiente de desenvolvimento de projetos pode-se relacionar os seguintes:

\begin{tabular}{|c|c|c|c|}
\hline & $\begin{array}{c}\text { Base } \\
\text { cópia }\end{array}$ & $\begin{array}{c}\text { Base } \\
\text { original }\end{array}$ & $\begin{array}{c}\text { manipulação/ } \\
\text { sep-integr }\end{array}$ \\
\hline apenas leitura & r- & r- & sep-integr \\
\hline flagrante & r- & rw & sep-integr \\
\hline isolado & rw & r- & sep-integr \\
\hline mut.excl & rw & rw & sep-integr \\
\hline independente & rw & rw & sep-integr \\
\hline "on-line" & rw & rw & manipulação \\
\hline
\end{tabular}

Fig5.2: Possiveis tipos de ligações entre a base cópia e a original.

- apenas leitura (r-): operações na cópia extraída e na original, restringem- se apenas a leitura.

- isolado (is): apenas à cópia possui autorização para escrita e leitura, enquanto que à versão original apenas leitura. 
- flagrante (n): à copia só é permitida operações de leitura, e à original as operaçōes de escrita e leitura são permitidas.

- mutuamente exclusivo (me): operaçōes de escrita e leitura autorizadas em ambas, entretanto apenas a copia ou a versão original será tomada como referência para integração, sendo desconsiderada a não selecionada. Tal seleção deverá ser feita pelo usuário no instante da integração.

- independente (in): tanto a versāo original quanto a cópia podem evoluir de maneira independente. Isto equivale a dizer que estão autorizadas as operacōes de escrita e leitura para cópia e original. Entretanto tais autorizaçōes estão limitadas a um subconjunto da situação inicial do registro de autorização da versão original.

- "on-line" (ol): tanto a versão original quanto a cópia podem evoluir. Entretanto qualquer alteração em uma das bases implicará que esta alteração seja repassada para as demais bases. Isto acarretará a necessidade do controle concorrência e integridade das bases.

- combinado (comb): quando a cópia e a original têm acesso constituído por combinaçōes descritas anteriormente, tem-se uma configuração heterogênea de autorizações. Este recurso é importante, pois a cópia ou a base de dados do MRO contém objetos, colónias, atributos e relacionamentos que podem ter características distintas para a distribuição. Por exemplo uma colônia pode ser separada para desenvolvimento isolado, enquanto consulta outra colónia que deve ficar estável (r-) para cópia e original.

Uma vez definida a separação, está também estabelecido o tipo de ligação entre a cópia e a versão original, as operaçōes de manipulação da base e posteriormente as possíveis integraçōes também já estão delimitadas e definidas.

Para dar uma visão geral das possibilidades da operação de distribuição do MRO, utiliza-se a figura 5.3, onde descrevem-se as sub-operaçōes de separação, manipulação e integração.

Nessa figura apresentam-se as possíveis formas de separação da Base de Dados, juntamente com a manipulação e a integração na operação de distribuição. A integração está caracterizada em funçāo do tipo de separação ocorrida, sendo que no caso r- a integração não existe, pois as versões original e cópia ficaram "congeladas".

Pode-se observar que na integração existe uma subárvore em que não se considera o fato de haver ou não um relacionamento de separação entre as mesmas. Tal procedimento apenas considera que deverá haver uma integração entre as bases. 


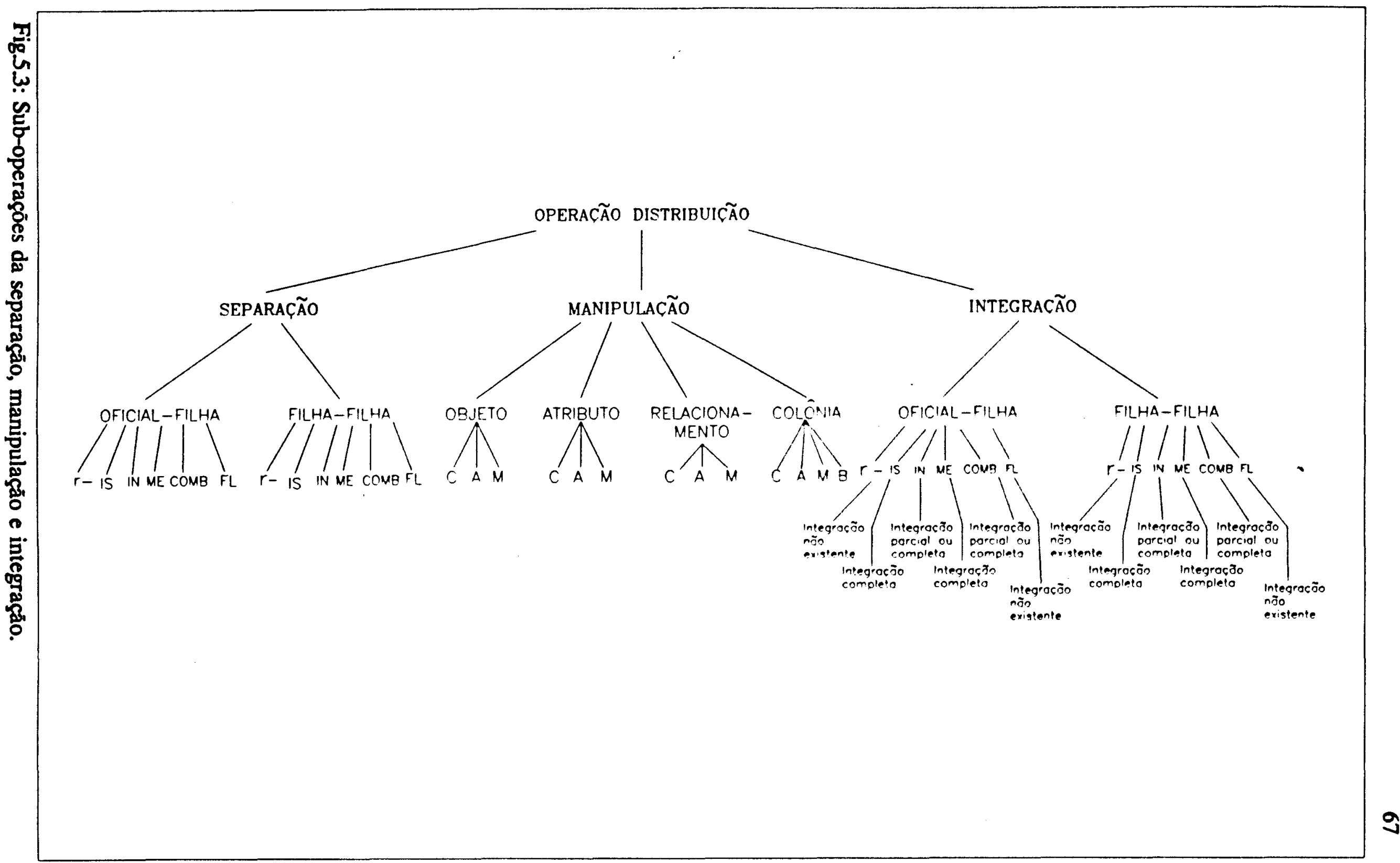




\subsection{1 - Granularidade.}

O conceito de granularidade ou atomicidade representa o menor tamanho de ftem, indivisível, tratado pela base de dados para a operação de distribuição. No caso convencional, a granularidade em geral é fixa e no MRO é variável, na medida em que a granularidade recai sobre os objetos, estes podem constringir colônias de objetos ou até mesmo constituir uma colônia de objetos que possuem relacionamentos e atributos. Esta granularidade, normalmente conhecida pelo nome de granularidade por predicado,torna-se não mais absoluta mas sim relativa à especificação do usuário. Se o usuário desejar distribuir apenas uma única colônia, que não constringe outras, a granularidade terá o tamanho da colônia em questão, caso contrário se deve ser distribuído uma colônia e as colônias que seus objetos constringem a mesma terá o tamanho das diversas colônias especificadas pelo usuário. A figura 5.4a ilustra os níveis possíveis de

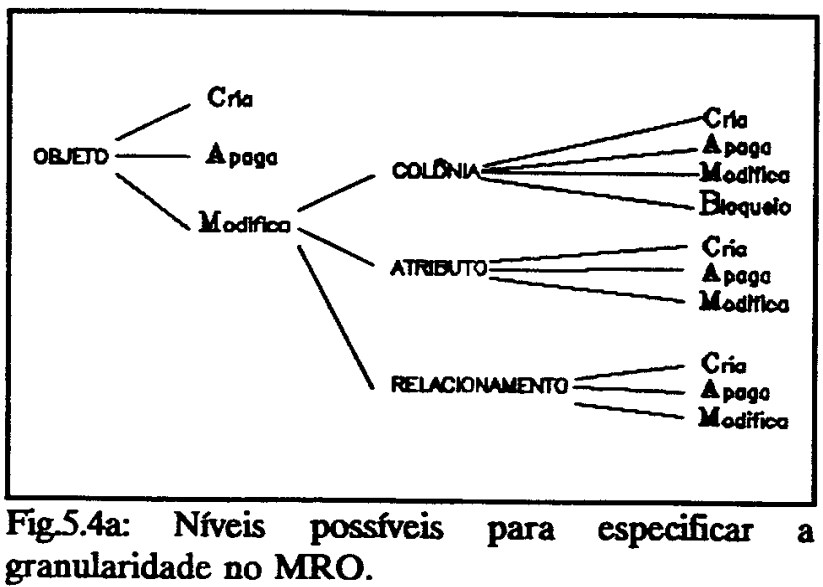
granularidade definida através da combinaçāo das operaçōes de: $\mathrm{Cria}(\mathrm{C})$, Apaga(A) ou Modifica(M): objetos, relacionamentos, atributos e colônias. A figura 5.4b exemplifica como a granularidade pode ser variável de acordo com a especificação do usuário.

Pode-se observar na figura $5.4 a$ que a colônia pode ser alterada apenas se o objeto puder ser modificado. Isto

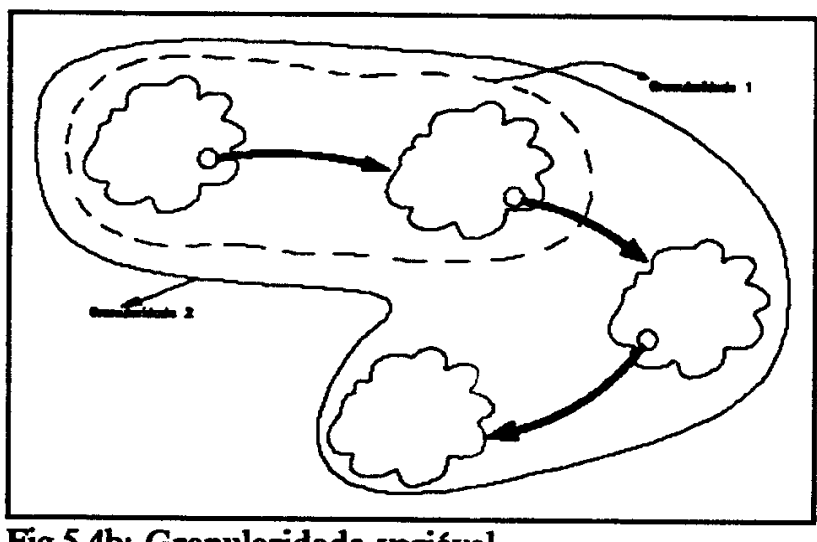

Fig.5.4b: Granularidade variável. significa que não só a colónia constrita pelo objeto poderá sofrer ou não alteraçōes, como também os atributos e relacionamentos do objeto em questão, de acordo com a autorização estabelecida.

As figuras 5.4a e 5.4b sugerem uma estrutura de dados para cada colônia, onde os níveis de autorizações devem ser especificados para as operações de escrita e leitura 
para objetos, relacionamentos, atributos e colônias constritas.

Para descreverem-se os niveis de autorização das operações efetuadas sobre as colônias, é necessário uma estrutura de dados baseada em registros, que contenha campos para armazenar informaçōes a respeito dos atributos, de relacionamentos, objetos constritos pela colônia em questão, e colônias de um nível hierárquico imediatamente inferior. Portanto, para cada colônia deverá haver um registro com os campos conforme mostra a figura 5.5.

Cada campo é subdividido de modo que, para os objetos existem dois subcampos, quatro para colônias, e para atributos e relacionamentos três subcampos. Cada subcampo, com exceção do subcampo bloqueia colônia (colbloq), possui dois tipos de valores que representam o tipo de acesso para operações:

0: bloqueia as operações de escrita e leitura do subcampo em questão permitindo apenas leitura.

1: libera as operações de escrita e leitura do subcampo em questão.

Quanto ao subcampo colbloq, responsável por bloquear qualquer

\begin{tabular}{|c|c|c|c|c|c|c|c|c|c|c|c|}
\hline c & $A$ & C & $A$ & $M$ & B & C & $A$ & $M$ & C & $\boldsymbol{A}$ & $\mathbf{M}$ \\
\hline 0 & 0 & 0 & 0 & 0 & 1 & 0 & 0 & 0 & 0 & 0 & 0 \\
\hline & & & & & & & & & & & \\
\hline
\end{tabular}

Fig.55: Descrição do registro de autorização para cada colônia. operação a ser realizada na colônia, se seu conteúdo for 1 significa que a colônia em questão pode ser acessada, se for 0 significa que todas as operações inclusive as de leitura não são permitidas.

\subsection{2 - Contexto para Distribuição.}

O controle de acesso no MRO é feito através de colônias. Estas contêm registros de autorizaçāo conforme mostra a figura 5.5.

Portanto para cada colônia que deve ser copiada é preciso considerar seu respectivo registro de autorizaçāo.

No MRO os dados são representados através de objetos que são constritos ou constrigem uma colônia, constituindo assim uma estrutura hierárquica que deverá ser mantida na operação de distribuição.

Para manter esta estrutura na distribuição, é necessário e suficiente considerar apenas os objetos que constringem as colônias hierarquicamente envolvidas na base de dados. Denomina-se contexto de uma colónia $\beta$ o caminho hierárquico de objetos que 
constringem colónias, até atingir a colônia $\beta$. A figura 5.6 ilustra o contexto colónia indicada através de uma seta, e também os registros de autorização das várias colônias inclusive de uma colônia hierarquicamente inferior, constrita por um objeto pertencente a colônia na qual se deseja fazer as alterações.

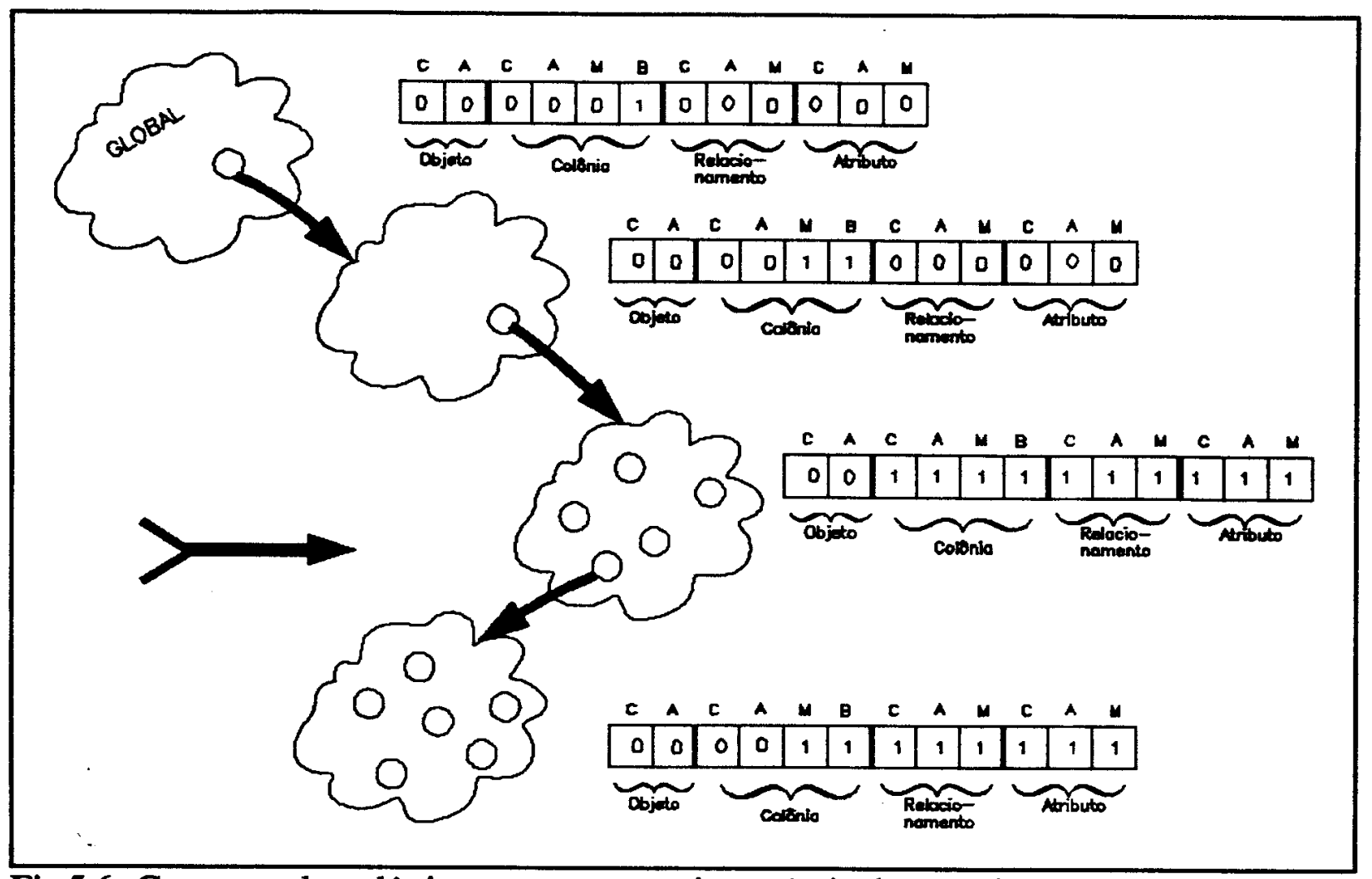

Fig.5.6: Contexto da colônia com os respectivos níveis de autorização.

Pode-se observar através da figura 5.6, que os subcampos dos registros de autorização de operaçōes desde a colônia global, até atingir a colônia imediatamente acima da qual se deseja realizar as operações de atualização são bloqueados para escrita, ou seja, todos os subcampos contêm zeros. $O$ registro de autorizaçāo da colônia imediatamente acima da seta, também tém todos os seus subcampos zerados, com exceção dos subcampos modifica colônia (colmod) e bloqueia colônia (colbloq) que têm valor 1 como conteúdo. Isto significa que as colônias constritas pelos objetos dessa colônia têm permissão para realizar atualizações. Portanto a colônia indicada pela seta está autorizada a realizar atualizações. A abrangência das operações de atualização dessa colônia em particular, estará condicionada ao seu registro de autorização.

Especificamente na figura 5.6, na colônia indicada pela flecha, as operações de \{cria e apaga objetos, cria, apaga e modifica relacionamentos e atributos, modifica e bloqueia colônia\} estão autorizadas, entretanto cria e apaga objetos não estão 
permitidas. A autorização para modificar colônia significa que qualquer colónia hierarquicamente inferior está liberada para as operaçōes de atualização, caso contrário o subcampo estaria com valor zero, impedindo assim o acesso para operações de escrita.

Para reproduzir o contexto na base cópia, é necessário para cada colônia apenas copiar o esquema que rege a colônia em questão e o objeto que constringe a colónia hierarquicamente inferior com seus identificadores, e finalmente impedir que a colonia seja apagada, atribuindo o valor 0 para o subcampo "colónia apaga" do registro de autorização.

\subsection{3 - Registros da Operação Distribuição.}

Para uma operação de distribuição, os registros de autorizaçōes deverão ser combinados com os tipos de ligaçāo entre a cópia e a versão original.

Cada operação de cria, apaga ou modifica dos vários campos em questão será definida em função do tipo do relacionamento entre a cópia e a original especificada na operacāo de distribuição. A figura 5.7 resume os tipos de relacionamentos entre a cópia e a versão original, e também a configuração de cada registro.

Quando as operações de escrita e leitura são permitidas para base original ou cópia, não significa necessariamente que todos os subcampos terão tal autorização. Estas operaçōes estão limitadas pelo registro de autorizaçāo de cada colônia. Sendo assim as operaçōes de escrita e leitura serão permitidas em função da configuração inicial da colônia original. Na figura 5.7, para representar tal situação, utilizam-se as palavras: subconjunto da configuração inicial da versão original. Note-se que é considerado inicialmente o conjunto de todos os subcampos da versão original que permitem operacōes de escrita, entretanto tal configuração inicial pode ser alterada pelo usuário na definiçāo da operaçāo distribuição. Assim o subconjunto de subcampos que permitem escrita resultante pode não ter todas as informações dos subcampos originais.

Além do registro de autorizaçāo mostrado na figura 5.6, é necessário um novo registro que armazene as informações referentes ao tipo de ligaçāo entre a base original e a cópia, no qual cada subcampo possa ter como conteúdo um dos possíveis tipos de ligação: $\mathbf{r - ,}$ is, $\mathbf{n}$, me, in. 


\begin{tabular}{|c|c|c|}
\hline & cópia & original \\
\hline apenas leitura(r-) & $\begin{array}{l}\text { todos os subcampos } \\
\text { com zeros }\end{array}$ & $\begin{array}{l}\text { todos os subcampos } \\
\text { com zeros }\end{array}$ \\
\hline isolado(is) & $\begin{array}{c}\text { subconjunto da } \\
\text { configuraçāo inicial } \\
\text { da versāo original }\end{array}$ & $\begin{array}{l}\text { todos os subcampos } \\
\text { com zeros }\end{array}$ \\
\hline flagrante(fl) & $\begin{array}{l}\text { todos os subcampos } \\
\text { com zeros }\end{array}$ & $\begin{array}{c}\text { subconjunto da } \\
\text { configuração inicial } \\
\text { da versão original }\end{array}$ \\
\hline $\begin{array}{l}\text { mutuamente exclusivo } \\
\text { (me) }\end{array}$ & $\begin{array}{c}\text { subconjunto da } \\
\text { configuração inicial } \\
\text { da versão original }\end{array}$ & $\begin{array}{c}\text { subconjunto da } \\
\text { configuração inicial } \\
\text { da versão original }\end{array}$ \\
\hline independente(in) & $\begin{array}{c}\text { subconjunto da } \\
\text { configuração inicial } \\
\text { da versão original }\end{array}$ & $\begin{array}{c}\text { subconjunto da } \\
\text { configuração inicial } \\
\text { da versão original }\end{array}$ \\
\hline
\end{tabular}

Fig.5.7: Tipos de ligaçōes entre base original e cópia, com os valores dos subcampos.

Cada processo de distribuiçāo utiliza três registros para cada colônia copiada. $O$ registro reg1 armazena as informações referente ao tipo de ligaçāo entre a base cópia e a original, para cada subcampo. Os outros dois registros, reg2 e reg3 armazenam respectivamente as informaçōes das autorizaçōes de escrita e leitura para a base original e cópia.

A figura 5.8 apresenta a especificação do conjunto de todos os registros necessários para a operação de distribuição. Cabe observar, que não tem sentido atribuir valores ao subcampo colbloq do reg1, uma vez que este subcampo é responsável apenas pelo bloqueio ou não, do acesso a uma determinada colônia.

\subsection{4 - Modelagem da Operação de Distribuição Através do MRO.}

A operação de distribuição pode ser modelada pelo próprio MRO, e assim uma 


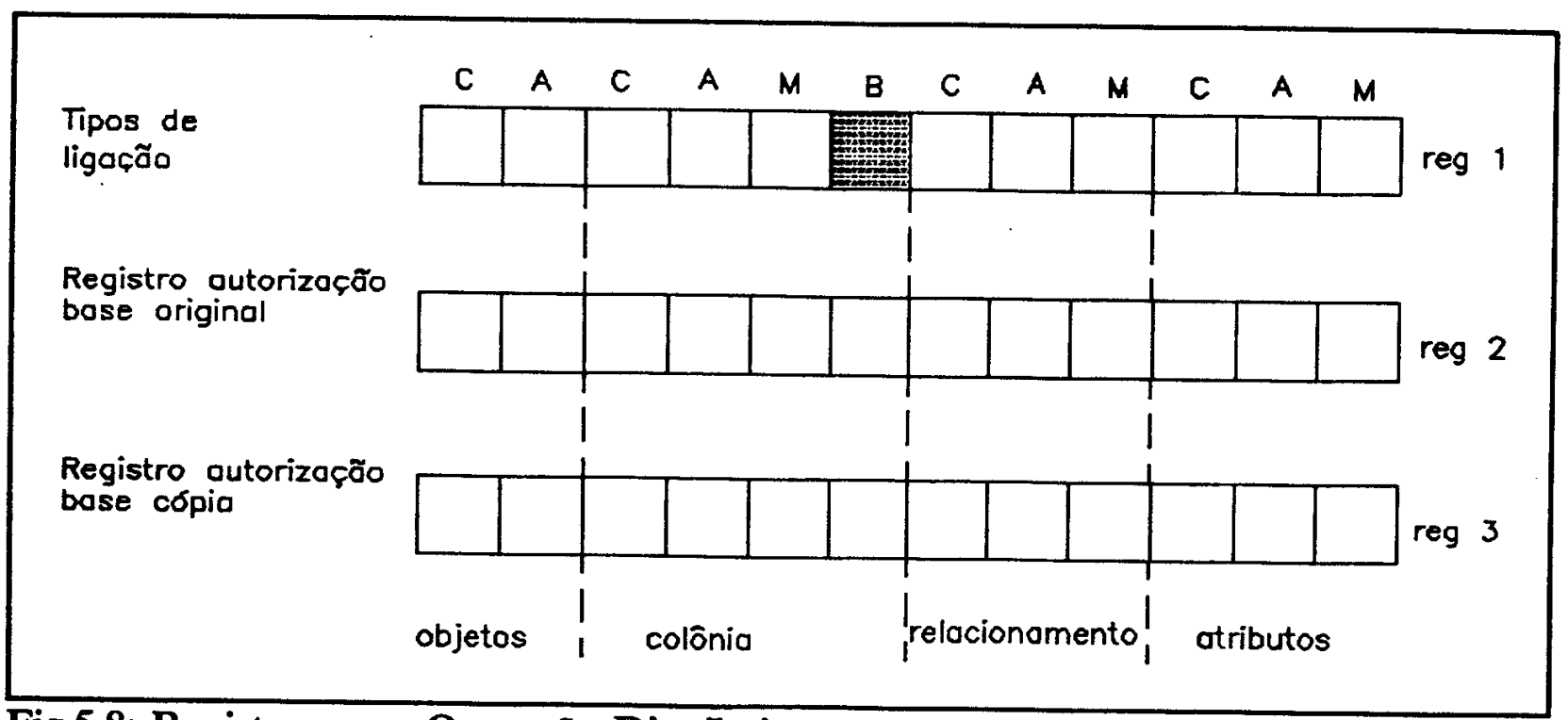

Fig.5.8: Registros para Operação Distribuição.

especificação possível é descrita através das figuras 5.9 e 5.10, as quais apresentam a colônia $\alpha$, que deverá conter as informações da operação de distribuição, incluindo a configuração da versão original e da cópia.

Como mostra a figura 5.9, a definição da operação de distribuição será feita através do esquema do MRO, onde a operação de distribuição é definida na colônia $\alpha$ controlada pelo sistema, a qual constringe objetos de tipo Operação Distribuição(OD), que se relacionam com outros objetos de tipo colônia-original, os quais representam as colônias que se submeterão ao processo

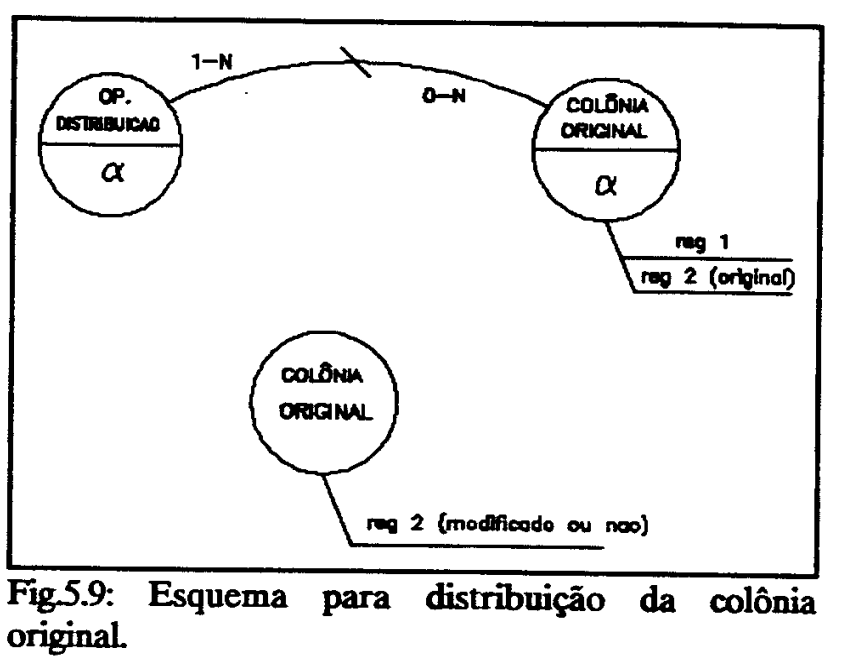
de distribuição. A multiplicidade é de 1-N no relacionamento OD-Colônia Original e 0-N do relacionamento colônia Original-OD. Cada colônia original que sofrerá uma operação de distribuição possui dois atributos: 1) registro da forma da operação distribuição (reg1 da fig.5.8); 2) registro da autorização das operaçōes na colônia original antes do início da distribuiçāo(reg2 da fig.5.8).

Ainda na figura 5.9 tem-se a instância da colônia original que será distribuída, onde há um único atributo, que tem como conteúdo o registro das operaçōes autorizadas para a distribuição definidas pelo usuário. 
O esquema de distribuição da colónia cópia apresentada através da figura 5.10 é análogo ao da colônia original, diferindo entretanto, na multiplicidade e no atributo da colônia cópia.

Na colônia $\alpha$ da colónia cópia o relacionamento OD-colônia cópia tem multiplicidade 1-N, que é a mesma para o relacionamento colónia cópia-OD. Isto

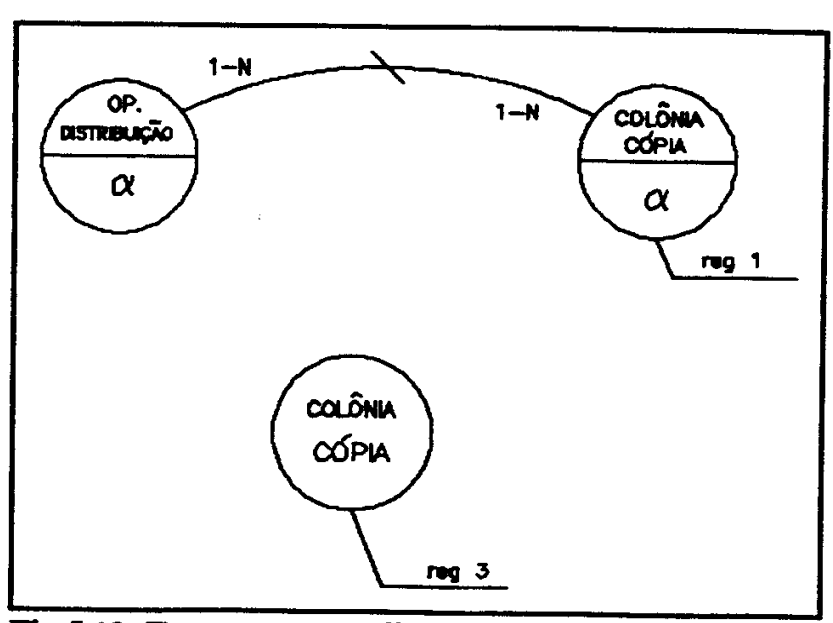

Fig.5.10: Esquema para distribuição da colônia cópia. se deve ao fato que, existindo uma cópia, necessariamente deve existir uma operação de distribuição correspondente. No caso da operaçāo de distribuiçāo da colônia original, independente da existência da colônia original a operaçāo de distribuição existe e está definida.

A colônia cópia possui um único atributo que é a forma de distribuição tendo como conteúdo o reg1 da fig.5.8.

A instância da colônia cópia que é mostrada também através da fig.5.10, possui apenas um atributo que tem como registro as operaçōes autorizadas para a colônia cópia definidas pelo usuário.

\section{3 - Operação Distribuição.}

\subsection{1 - Processo de Separação.}

A operação de distribuição de uma base de dados apoiada no MRO é constituída de três fases: separação, manipulação e integração. A fase de separação, na qual pressupōe-se a interferência do usuário para especificar o tipo de ligação que a versão original estabelecerá com a cópia, deverá ser realizada partindo-se do registro de autorização original de cada colônia da Base MRO que se deseja separar. De acordo com nível de autorização permitido, é que será definido o tipo de ligaçāo da distribuição entre a versão original e a cópia. 
Para efeito da separação, cada campo do registro de autorização deverá ser analisado de forma independente. Se estiverem permitidas apenas operações de leitura em um determinado campo, então tanto a colônia da base original quanto a colónia cópia resultante do processo de separação deverão permitir apenas as operaçōes de leitura. Neste caso, o tipo de ligaçāo estabelecida será r-.

Caso o campo em questão esteja liberado para as operaçōes de escrita e leitura, existirão cinco possibilidades no processo de separação para estabelecer o tipo de ligação entre a cópia e a versāo original: apenas leitura(r-), isolado(is), flagrante(n), mutuamente exclusivo(me) e independente(in). Na figura 5.11 é mostrado apenas um campo do registro de autorizaçāo, com os devidos valores para as operaçōes permitidas, tanto na cópia como na versão original. Na mesma figura convencionou-se o valor 1 para indicar que as operaçōes de escrita e leitura estão autorizadas e 0 para indicar que apenas as operações de leitura estão autorizadas. Em um campo do registro de autorização para distribuiçāo existem três subcampos: um que indica o tipo de ligação, um que indica a autorização resultante da colônia original, e outro que indica a autorizaçāo resultante da colônia cópia.

Quando uma informação na base original estiver com leitura proibida, o processo de separação não irá levar essa informação para a base cópia. Portanto, toda a informaçāo levada para a base cópia estará liberada para leitura ou para leitura e escrita:

No tipo de ligação r- tem-se os dois subcampos de autorização zerados. No isolado tem-se zero para o subcampo da versão original e 1 para o subcampo da cópia, permitindo assim apenas operaçōes de leitura para a original, e escrita e leitura para a cópia O tipo flagrante apresenta o subcampo original com valor 1 e 0 para copia, permitindo assim escrita e leitura para original e apenas leitura para cópia. $O$ tipo mutuamente exclusivo, com valor 1 para original e cópia, permite a evolução tanto da cópia quanto da original, com a restrição de que apenas uma configuração deverá ser considerada; porém posterga-se tal decisão para o processo de integração. Finalmente o tipo independente, com valor 1 para original e cópia, permite a evoluçāo tanto da original quanto da cópia.

O tipo de ligaçāo independente entre a versão original e a cópia, onde ambas podem evoluir independentemente, tem como conseqüência um processo de integração que dificilmente pode ser tratado automaticamente, em vista dos inúmeros caminhos que, tanto a versāo original quanto a cópia, podem assumir em suas evoluções. Neste 


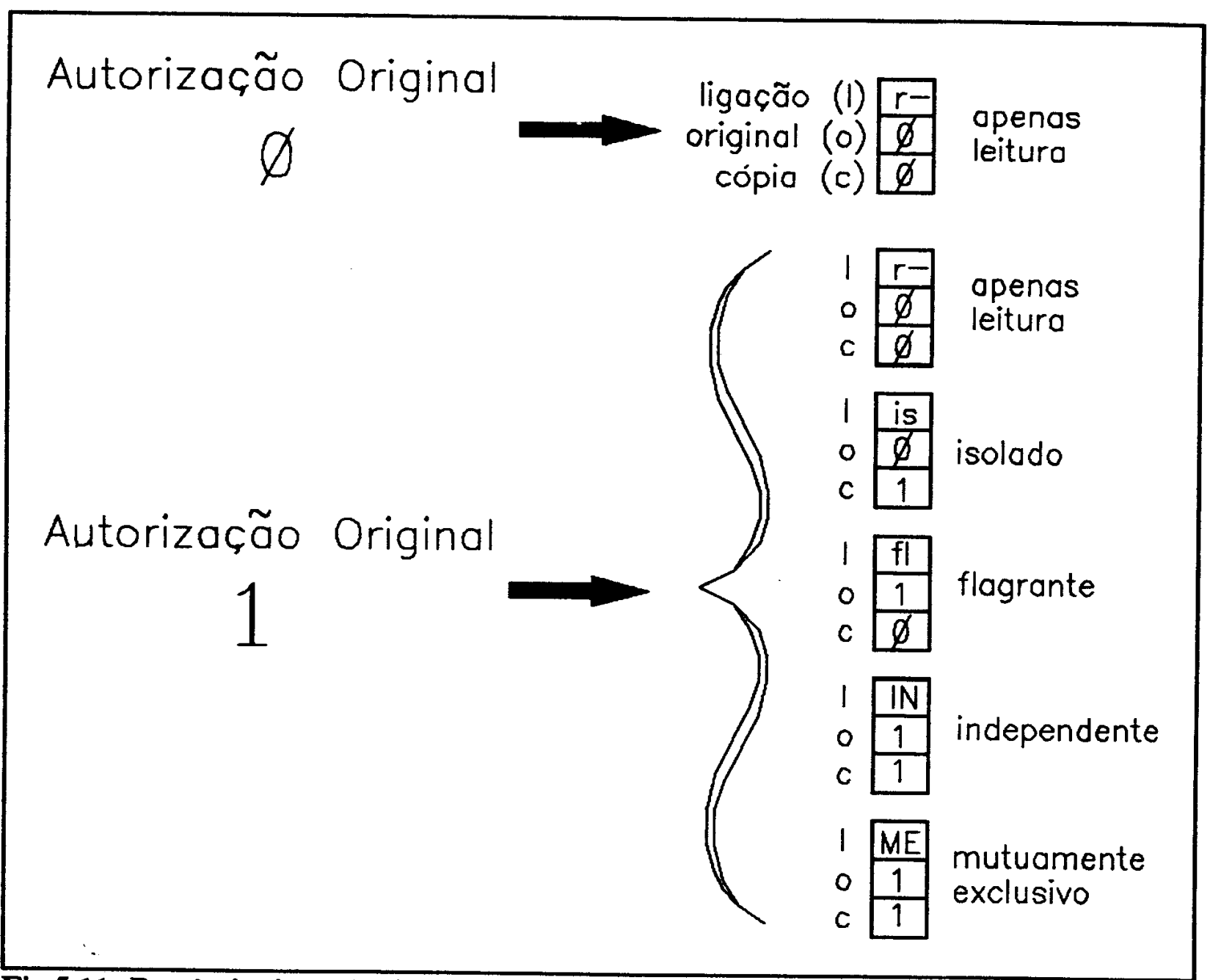

Fig.5.11: Possíveis tipos de ligações para a operaçāo separação.

caso, como será descrito mais detalhadamente na seção 5.3.3, ficará sobre a responsabilidade do usuário definir o significado do processo de integração.

No tipo independente não é possivel garantir a atomicidade e portanto a serialização no processo de integração. Isto se deve ao fato de que a inversão da ordem temporal das operações de integração entre várias operações de distribuição, gera resultados distintos. Este aspecto será abordado novamente no processo de integração descrito na seçāo 5.3.3.

\subsubsection{1 - Geração_do_Registro_de_Autorização(col,regmasc, $\rightarrow$ reg1,reg2,reg3).}

Para tratar as possibilidades na geraçāo do registro de autorização das colônias cópias é necessário uma primitiva que será acionada pela primitiva 
Prepara_Colónia(col). A seguir apresenta-se tal primitiva com o nome de Geração_do_Registro_de_Autorização. Esta primitiva tem a funçāo de ler o registro de autorização da colônia a ser distribuída e, para cada subcampo, estabelecer os tipos de ligações permitidas ( $\mathrm{r}-$, is, $\mathrm{fl}, \mathrm{me}, \mathrm{in}$ ), atribuindo valores aos registros 1,2,3 utilizados na operação de distribuição. Nos passos P1 a P5 tem-se respectivamente a atribuiçāo do valores dos subcampos referentes aos tipos de ligação : $\mathbf{r}$, is, $\mathbf{n}$, $\mathbf{m e}$, in ; entre a base original e a cópia. O passo P6 permite forçar que determinadas operações para criar, apagar, e modificar possam ser proibidas tanto na base cópia quanto na original, independentemente do tipo de ligação definido.

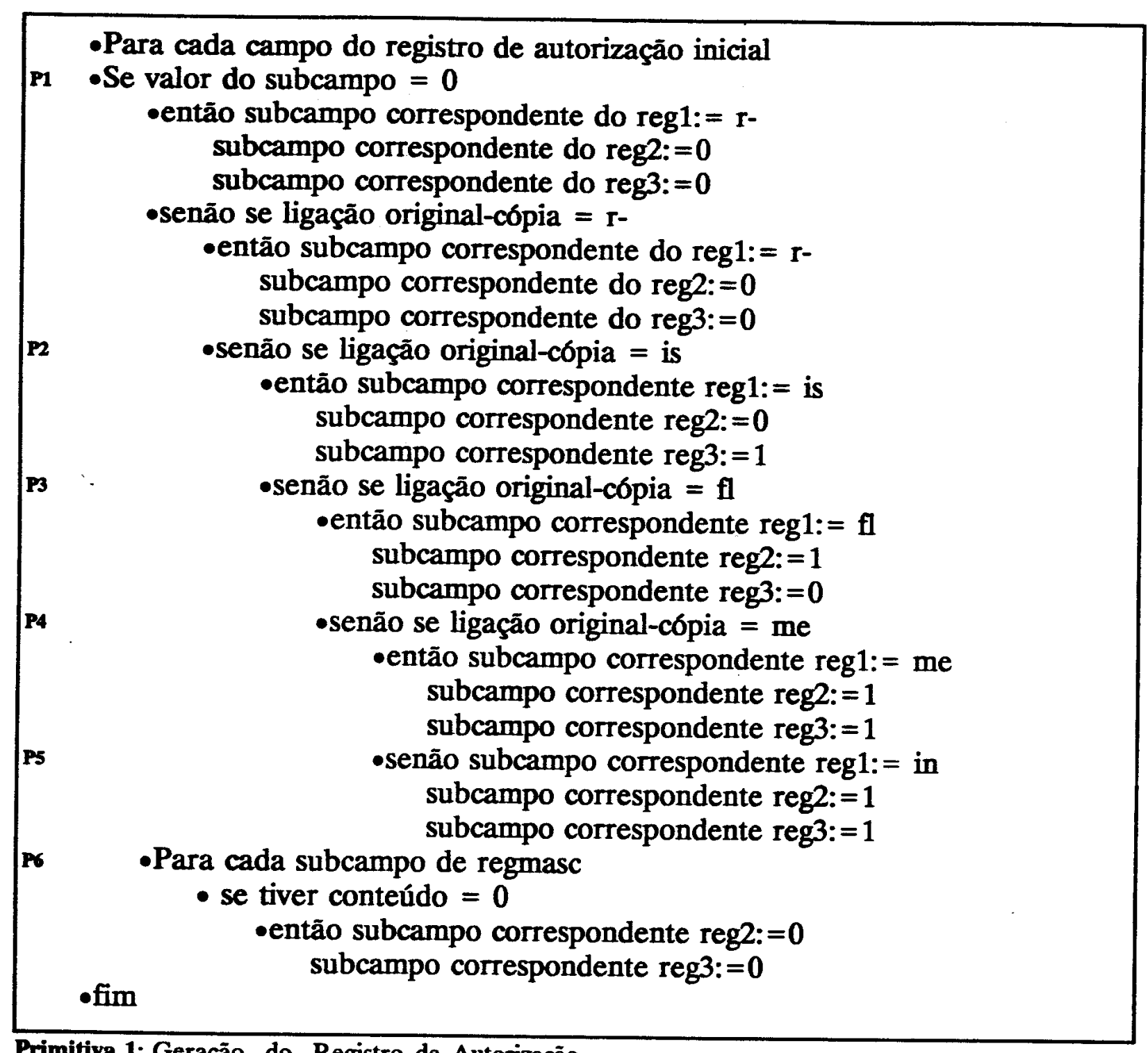

Primitiva 1: Geração_do_Registro_de_Autorização. 
5.3.1.2 - Operaçáo_Separaçáo.

O processo de separação de colónias tem como objetivo a reprodução de objetos, relacionamentos, atributos e colônias constritas para a base cópia. Para isso, é preciso avaliar os relacionamentos de objetos que tenham como destino objetos pertencentes a colónias que nāo devem ser levadas para base cópia. Estes relacionamentos são chamados de relacionamentos de interface do processo de separação, ao passo que aqueles que ocorrem entre objetos que habitam colônias que devem ser distriburdas são chamados de relacionamentos de conteúdo.

A separação é realizada através de uma primitiva principal com o nome de Operaçāo_Separaçāo, que tem como funçāo criar as condiçōes iniciais para o processo de separação propriamente dito. As açōes de P1 se caracterizam pela criação da base cópia: esquema e objetos para a distribuição. P2 é um procedimento interativo que enquanto houver colônia a ser distribuída deverá avaliar se é possível separá-lá, e se já não existe cópia. Se já existe cópia, então esta deve ser eliminada e substituída por uma nova cópia originada da operação de distribuição ora vigente. Esta operação é realizada pelo passo P3, que apaga a colónia cópia, restaura o registro de autorização original e ainda apaga os objetos do tipo "colônia distribuída tanto na cópia quanto na original. Isso é feito porque a existência de uma colônia na cópia, pode ser devido à necessidade de alguma outra colônia anteriormente separada, tal como cópia de contexto ou objeto destino de um relacionamento de interface. Isso implica que não é toda a colônia que está copiada, prejudicando assim a cópia dos objetos em falta. Apagando-se todos os objetos a menos daqueles que já constrigem colónias, garante-se que a cópia integral será feita sem problemas. Em P4 tem-se a caracterização do tipo de ligação entre a base original e a nova cópia, a verificação se a nova cópia é recursiva ou não, e finalmente a execuçāo da primitiva Separa_Colônia, que tem como argumento, a colônia a ser distribuída (col).

\subsubsection{3 - Separa_Colônia(col).}

A primitiva Separa_Colônia, que recebe como parâmetro a colônia col passada pela primitiva Operação_Separação, no passo P1 avalia se a cópia é recursiva ou não e atribui valores para os subcampos do registro máscara que sintetiza as autorizaçōes para as operações na colônia a ser copiada. Se for recursiva, o que equivale a dizer que 


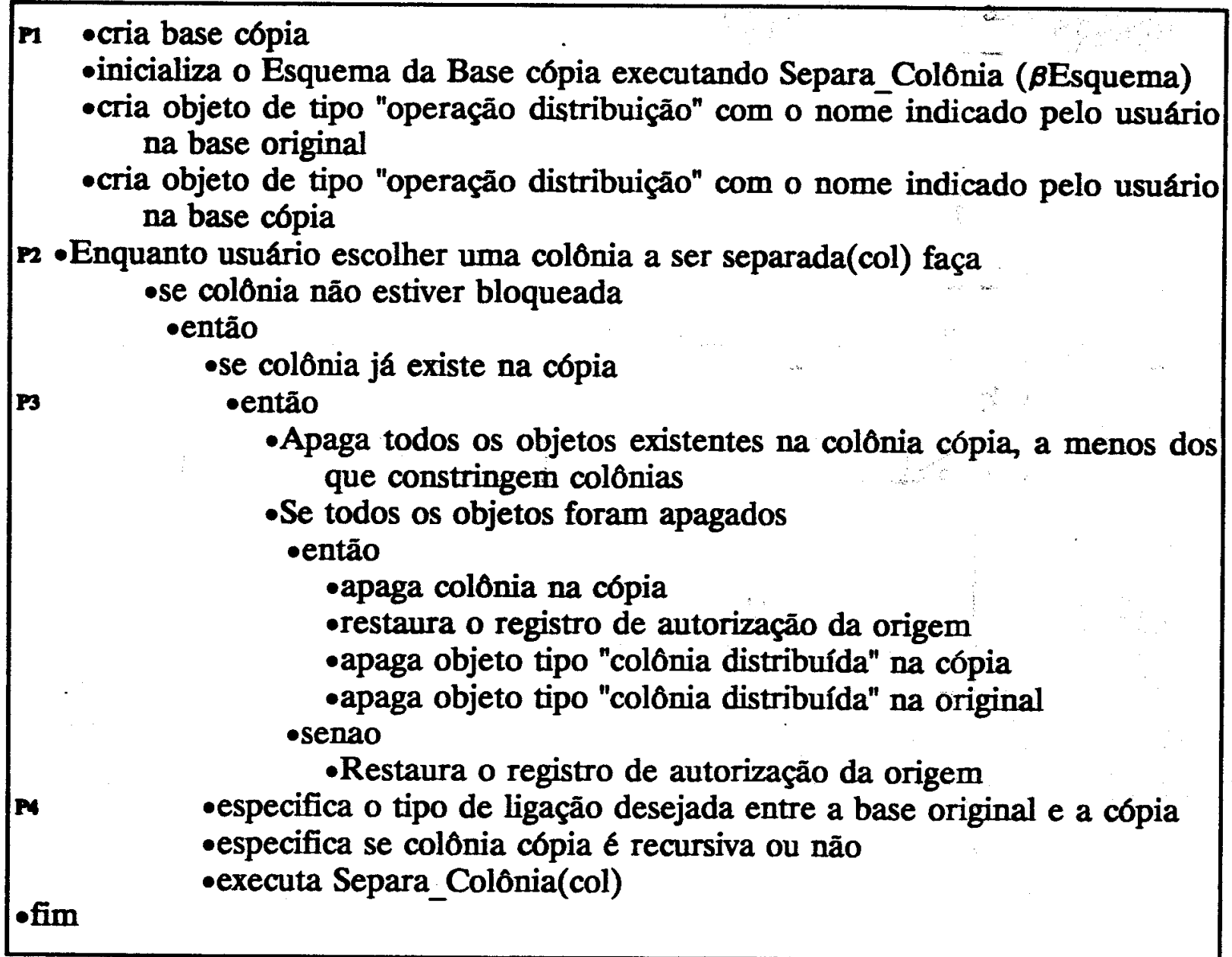

Primitiva 2: Operação_Separação.

as colônias constritas por objetos da colônia em questão, também serão reproduzidas, todos os subcampos deverão ter valor 1 . Caso contrário, os subcampos referentes a colônia (C,A,M) receberão valor 0 e os demais, valor 1 .

O passo P2 executa a primitiva Prepara_Colônia passando como parâmetro a colônia a ser distribuída (col) e o registro máscara de autorização das operações (regmasc).

O passo P3 executa a primitiva Copia_Colônia que tem como função copiar objetos, relacionamentos, atributos e colônias para a base cópia.

\subsubsection{4 - Prepara_Colónia(col, regmasc).}

Se a colônia em questão ainda nâo existir na distribuiçāo, a primitiva Prepara_Colônia é responsável pela criação do ambiente de distribuição na colônia $\alpha$, 


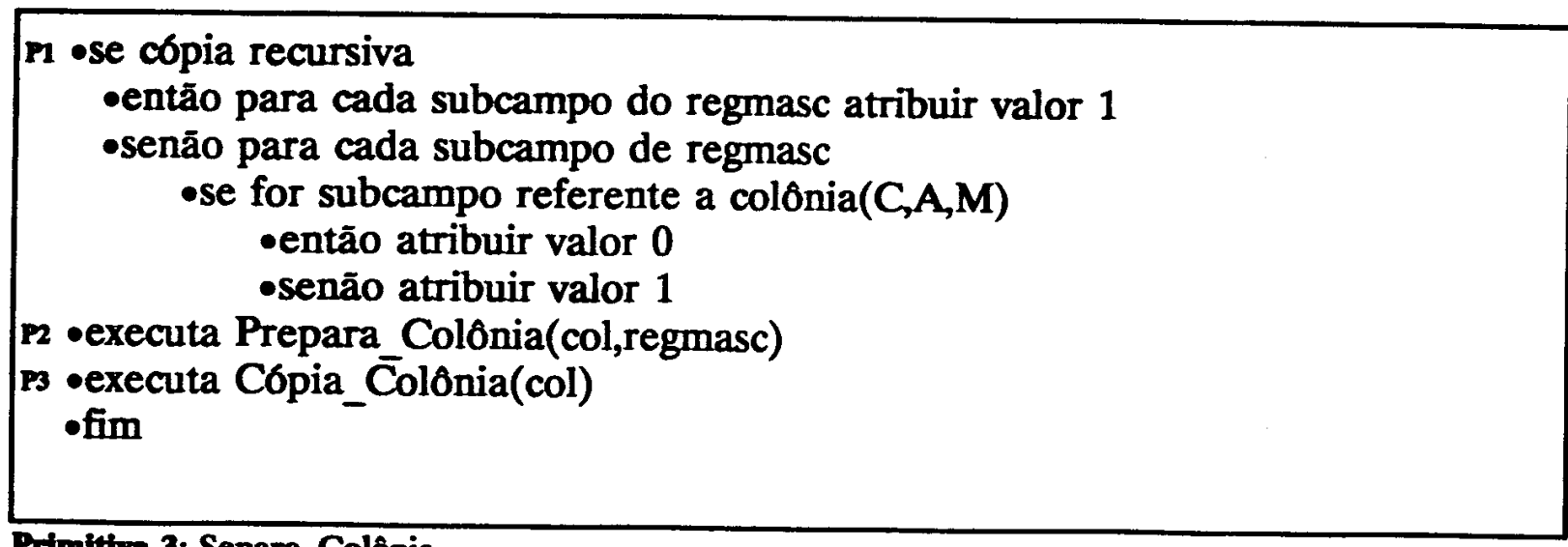

\section{Primittiva 3: Separa_Colônia.}

tanto na base original quanto na copia, conforme ilustram as figuras 5.9 e 5.10 .

Esta primitiva contém um conjunto de criaçōes de objetos e relacionamentos conforme descrito pelo passo $\mathbf{P} 1$. Como esta primitiva é também responsável pela preparação do "ambiente" para a reprodução da base, no passo P2 tem-se a "busca" do contexto da colônia em questāo, através da execuçāo da primitiva Busca_Contexto. Esta execuçāo se faz necessária, pois um objeto não pode ser acessado se nāo estiver associado ao seu contexto.

Na seção 5.3.1.8 apresenta-se a primitiva Busca_Contexto, que tem como parâmetro de entrada a colônia que deverá ser preparada para a distribuiçāo(col), e como saída seu respectivo registro de autorização(reg). P3 compara cada subcampo dos registros regmasc e reg usando uma função lógica "and". P4 estabelece os registros de autorização através da solicitação da execução da primitiva Geraçāo_Registro_Autorizaçāo. P5 associa os registros reg1, reg2 e reg3 com os registros de autorização de cada colônia envolvida na operação separação.

O passo P6 reproduzirá, se for necessário, o esquema que rege a colônia envolvida no processo de distribuição. Esta tarefa é realizada através da primitiva Separa_Colônia, tendo como argumento a colônia esquema.

\subsubsection{5 - Copia_Colónia(col).}

A primitiva Copia_Colônia tem no passo P1 a reprodução de objetos e seus atributos para a base cópia, atribuindo-lhes o "rótulo" de objeto "velho", para distinguílos daqueles que eventualmente serão criados pelos processos de manipulação posteriores. Isto se faz necessário pois o processo de integração, que será abordado mais adiante, exige uma distinçāo entre objetos novos e velhos na cópia. Para maiores 


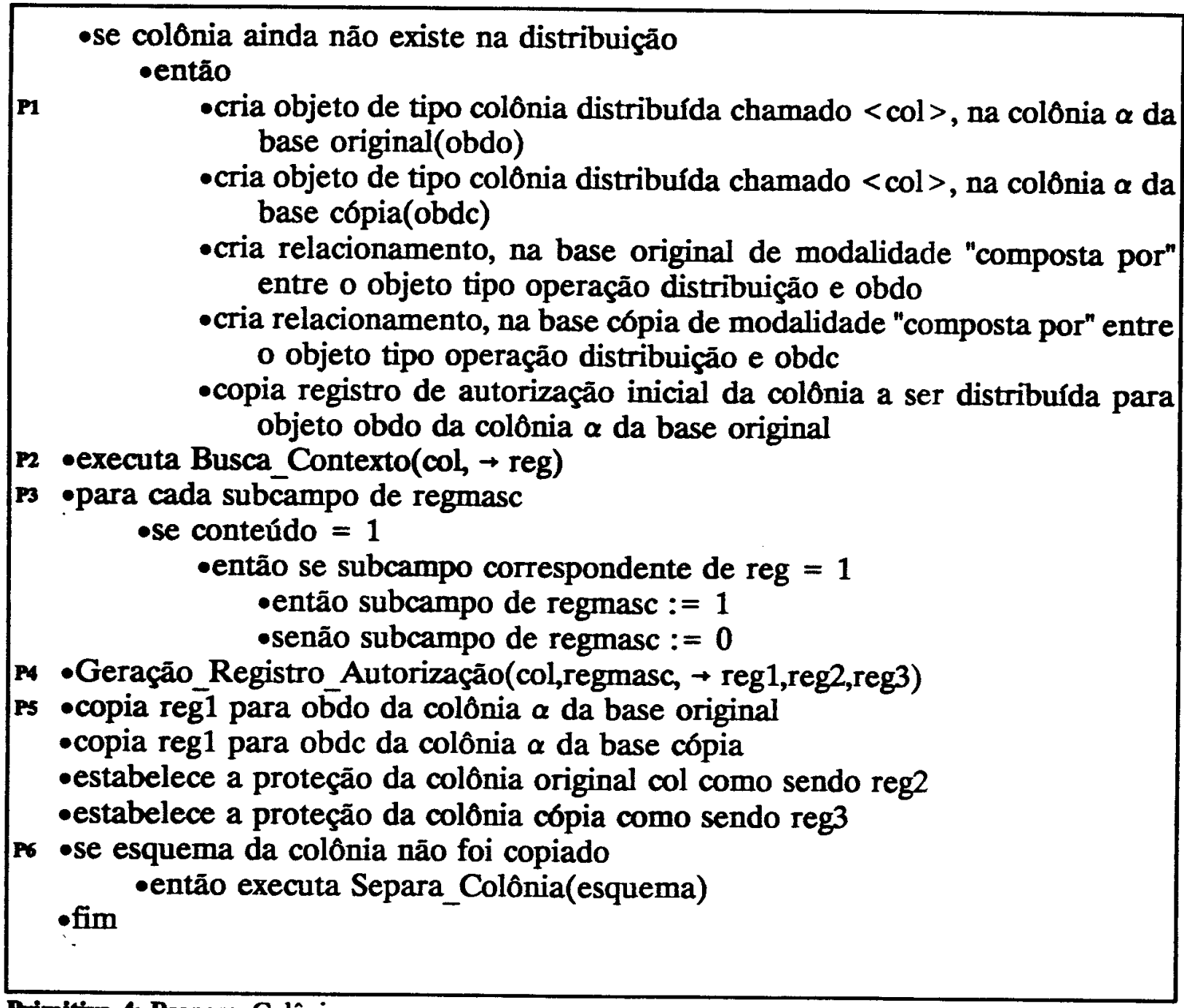

Primitiva 4: Prepara_Colônia.

detalhes a respeito da necessidade de marcação de objetos velhos ver seção 5.3.3.

No passo P2 cada relacionamento é analisado verificando, se é de interface ou de conteúdo. Se for de interface é tratado por P3 a P5, onde se a colônia já foi copiada, P4 avalia a existência do objeto, reproduzindo seus atributos, o relacionamento de interface e ainda avaliando se é permitido modificar os atributos deste relacionamento. Se a colônia onde habita um objeto acessado por um relacionamento de interface ainda não foi copiada, P5 executa a primitiva Tratamento_Relacionamento_Externo. No passo P6 tem-se a cópia do relacionamento de conteúdo, pois trata-se de relacionamento entre objetos pertencentes a mesma colônia.

\subsubsection{6 - Tratamento_Relacionamento_Externo(rel interface).}

Para a primitiva Tratamento_Relacionamento_Externo é necessário avaliar se é

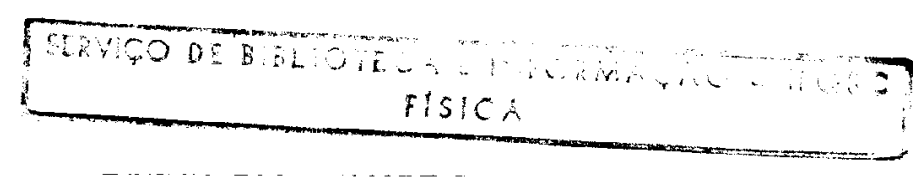




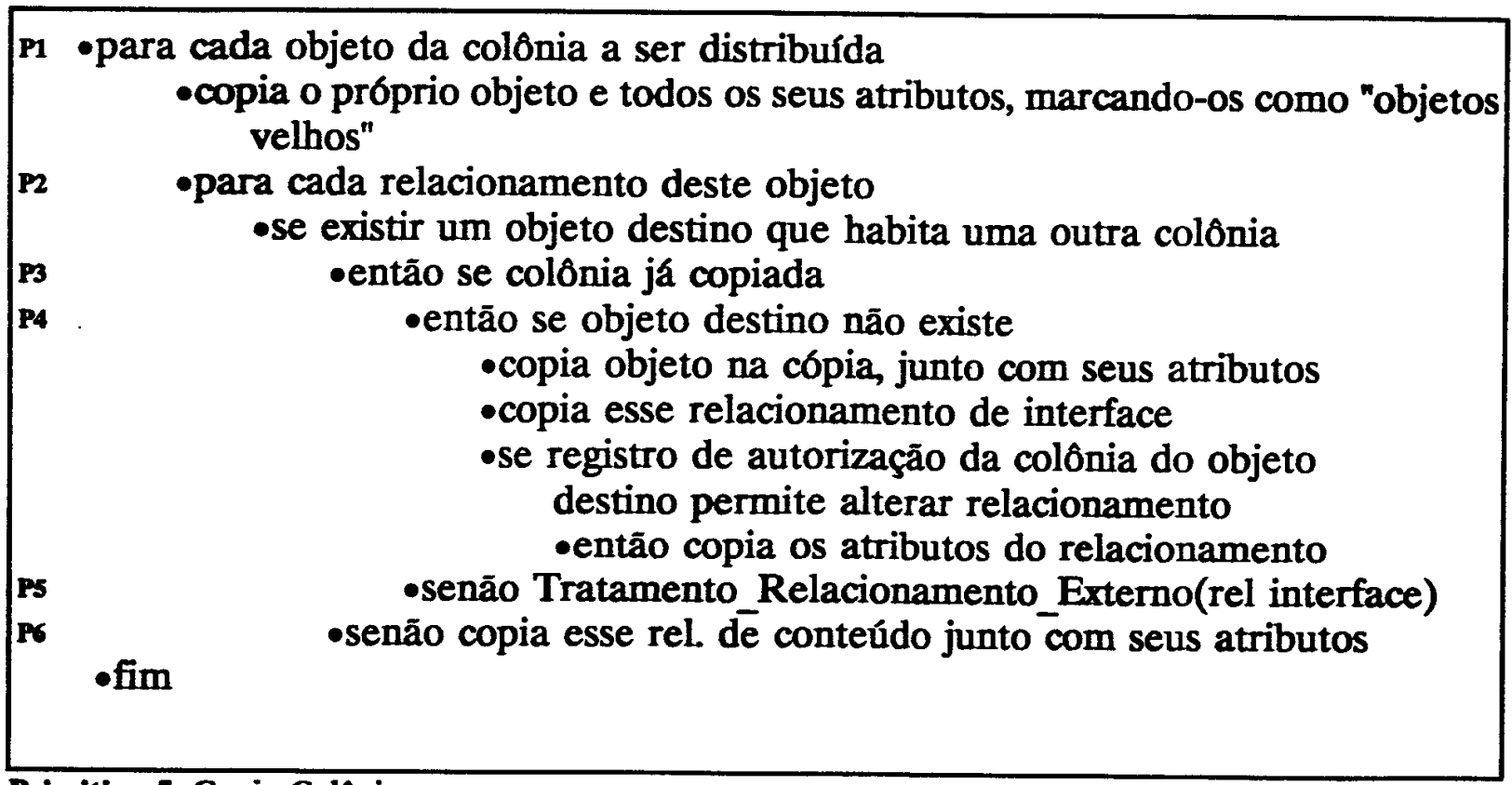

Primitiva 5: Copia Colônia.

permitido o acesso à colônia que constringe o objeto acessado através de rel.interface e que tipo de operaçōes são permitidas para esta colônia. Basicamente existem três casos de tratamento de permissões quanto aos objetos destinos dos relacionamentos de interface:

a) o registro de autorização original da colônia original do objeto destino, indica que a mesma está liberada apenas para a leitura. Neste caso a colônia onde habita o objeto destino não permite as operaçōes de criar e apagar objetos, e nem mesmo as alteraçōes nos atributos, relacionamentos e colônias. Com isto, na versāo cópia, a colônia que constringe tal objeto também não deverá permitir as alterações nos objetos, atributos, relacionamentos e colônias, apenas permitindo a operação de leitura. Dessa colônia, apenas o objeto destino deve ser copiado, juntamente com seus atributos, porém não são levados os seus outros relacionamentos.

b) o registro de autorização da colônia onde habita o objeto destino permite as operações de escrita e leitura. Para não haver conflito na base cópia, a colônia em que habita o objeto destino acessado através de um relacionamento de interface, somente terá permissão para modificar os atributos do relacionamento e criar ou apagar esse relacionamento. Nesta situação, também não se pode apagar o objeto ou alterar seus atributos. Isto foi definido utilizando como critério o fato de que a colônia que constringe o objeto e estiver com as operaçōes de escrita e leitura liberadas, deve ter prioridade para alterar seus objetos, atributos, relacionamentos e colônias. O objeto é copiado juntamente com seus atributos, porem não são levados os demais atributos. 
Copiam-se também todos os atributos desse relacionamento.

c) o registro de autorização da colônia do objeto destino não permite leitura. A colónia que constringe tal objeto não pode ser acessada. Neste caso, não há cópia da colónia acessada através do objeto destino. $O$ objeto que tem como relacionamento o objeto destino pertencente a outra colônia terá apenas seu relacionamento reproduzido, para impedir que o mesmo possa ser apagado durante a evolução da versão cópia.

A figura 5.12 ilustra os três casos descritos(a,b,c) apresentando as formas de relacionamentos, com os objetos destinos pertencentes a outras colônias, e ainda uma comparação entre as operações permitidas na versão original e as operações que deverão ser permitidas para a cópia.

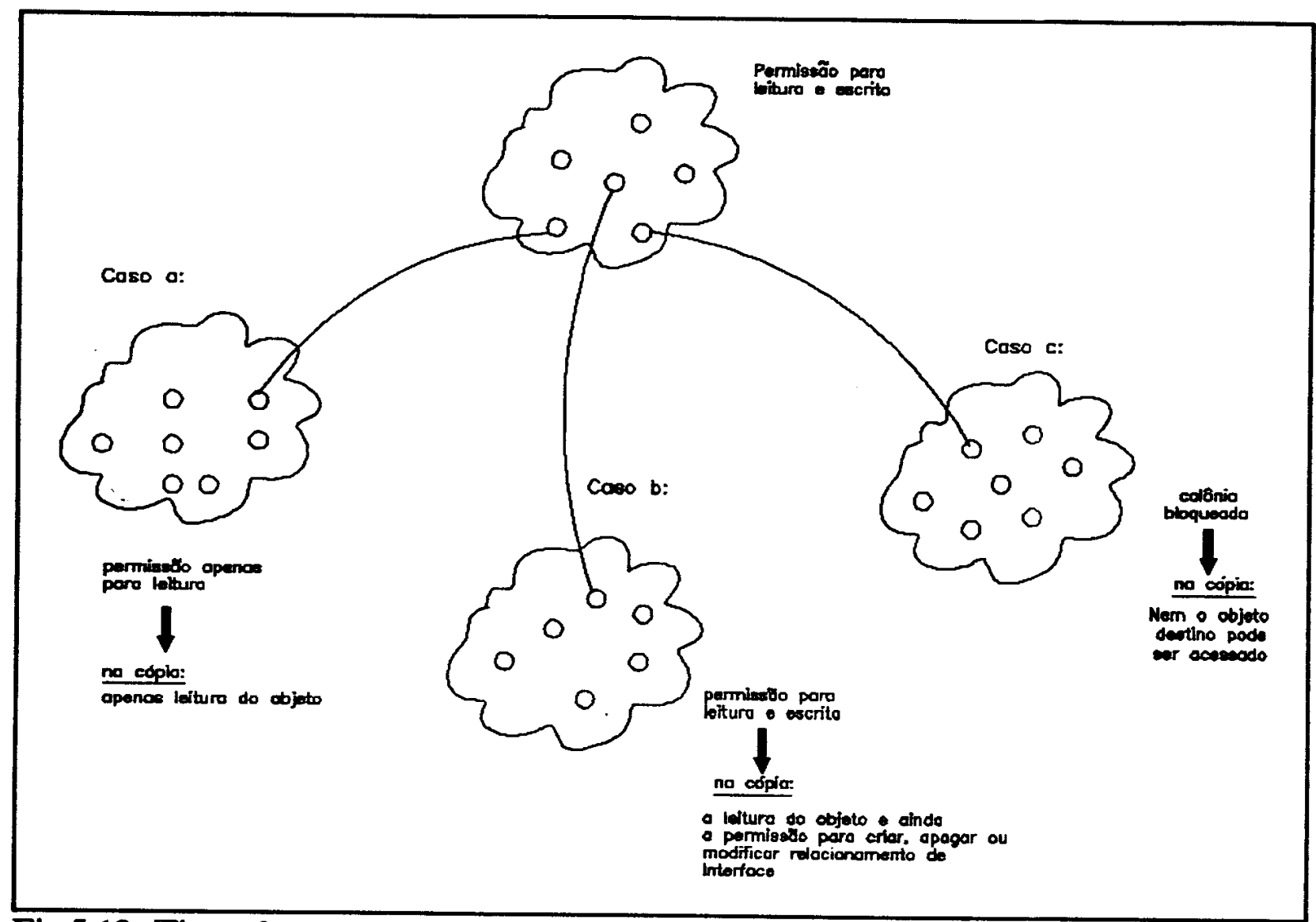

Fig.5.12: Tipos de acessos para os relacionamentos de interface.

A seguir descreve-se a primitiva que aborda os casos a), b) e c). Se puder acessar tal colônia, no passo P1 tem-se a avaliação do registro de autorização da colônia acessada através do rel. de interface. O passo P2 executa a primitiva Prepara_Colônia, tendo como parâmetro a colônia acessada pelo relacionamento de interface e o registro de máscara de autorização, que traz as informações a respeito do tipo de acesso permitido a colônia em questão. P3 reproduz objetos e seus atributos juntamente com 
o relacionamento de interface. P4 copiará os atributos do relacionamento de interface, se for permitido modificar relacionamentos.

Com isto, os casos a) e b) descritos anteriormente, são tratados através dos passos P2 e P3, sendo P4 um passo exclusivo do caso b). Finalmente o passo P5 é responsável pelo tratamento do caso c), onde a colônia do objeto destino não pode ser acessada. Para copiar o relacionamento de interface, é utilizada uma colónia "virtual" na base cópia, que está bloqueada para o acesso, inclusive de leitura.

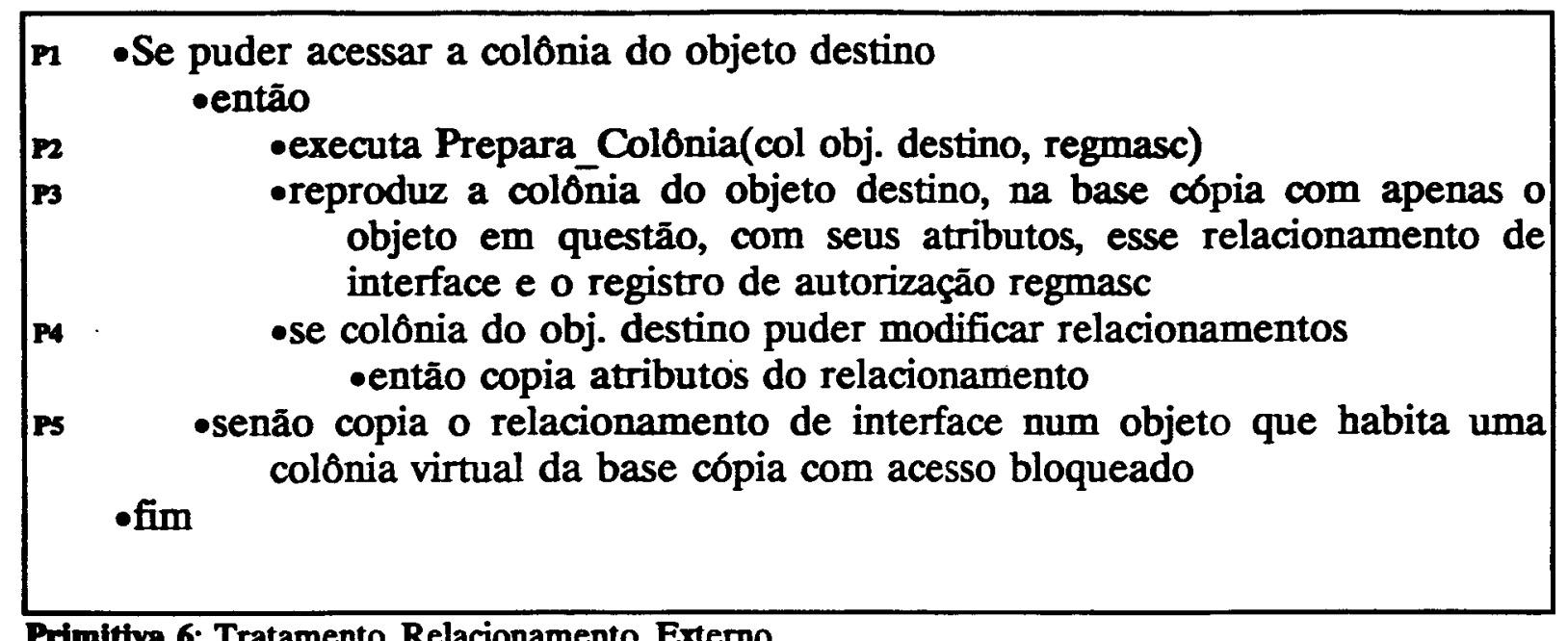

\subsubsection{7 - Busca_Contexto(col, $\rightarrow$ reg).}

A primitiva Busca_Contexto, que é executada pela primitiva Prepara_Colônia, tem como objetivo reproduzir o contexto para a base cópia, analisando cada registro de autorização para verificar se é possível copiar tal contexto. Como consequiência, tem-se o estabelecimento do tipo de acesso permitido para a colônia que será copiada, e a criação das colônias que constituem o contexto da base cópia.

No passo P1, tem-se a alteração dos subcampos ColMod e ColBloq do registro de autorização(regaut) de col. Estes subcampos recebem valor 1 e os demais valor 0 , que é a condição mínima na colônia imediatamente acima para que a colônia em questão possa ser acessada. O registro de autorizaçāo regaut será passado como parâmetro para a primitiva Busca_Contexto_int, juntamente com col executada por P2, que tem como objetivo "buscar" o contexto propriamente dito e ainda retornar o registro de autorização das operações, resultante da busca do contexto, em todas as colônias hierarquicamente 
acima da colónia em questão.

O passo P3 cria a colónia na base cópia. Em P4 tem-se a avaliação do subcampo ColBloq de regaut. Se for 0 significa que a colônia não pode ser acessada, caso contrário no passo P5 o subcampo será avaliado. Se um conteúdo for 0 , então o subcampo ColBloq receberá valor 1 e os demais 0 . Isto significa que a colônia somente terá permissão para leitura. Se o subcampo de ColMod for igual a 1, todo o registro de autorizaçāo inicial da colônia será repassado para reg. Em P6 tem-se a proibiçāo da colônia para as operações de apaga objeto, através do registro de autorização reg, pois ou existe um relacionamento de interface acessando o objeto em questão, ou então colónias constritas por este mesmo objeto. $O$ registro (reg) no passo P7, retornará para a primitiva que originou a execuçāo de Busca_Contexto.

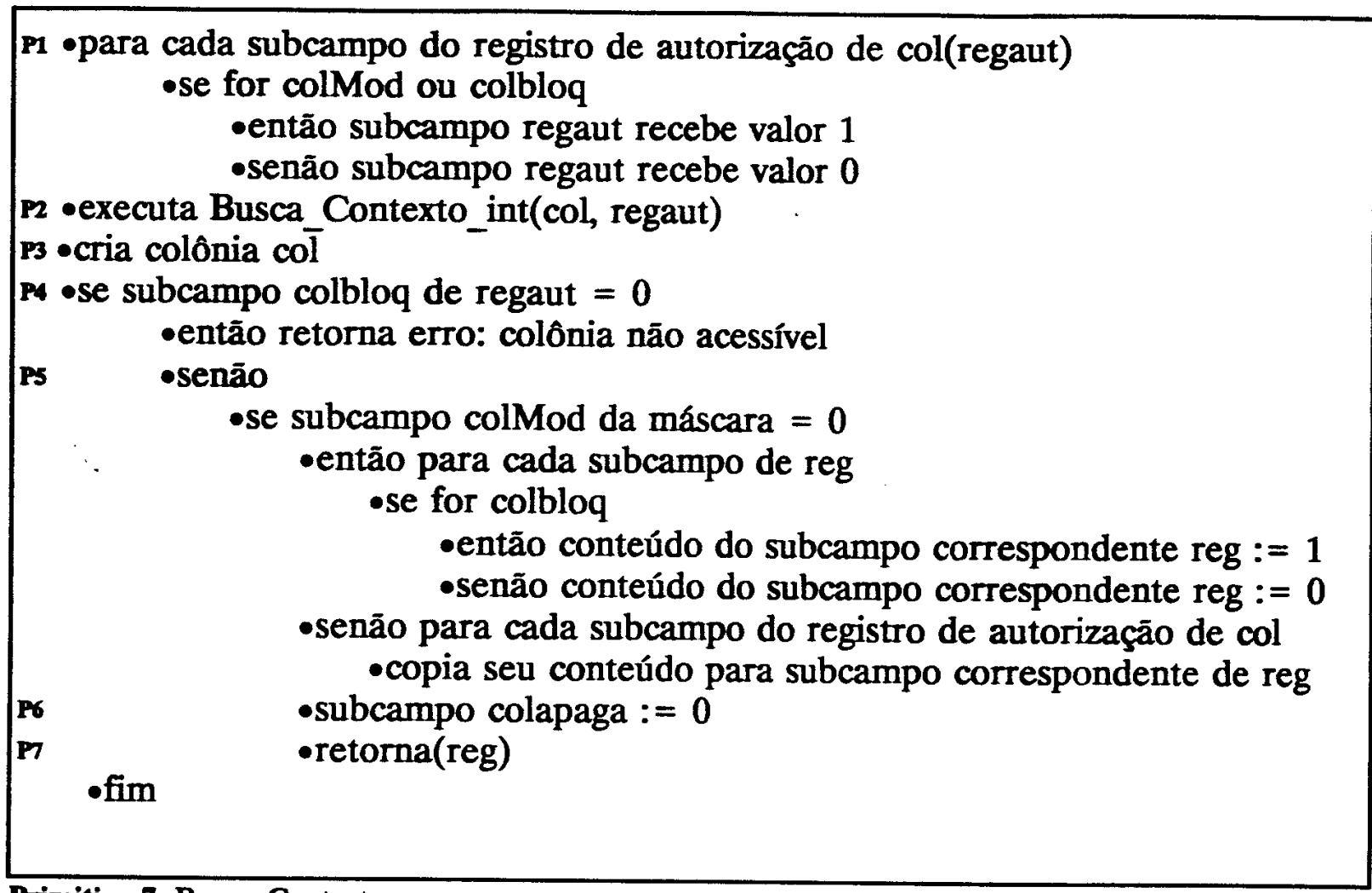

Primitiva 7: Busca_Contexto.

\subsubsection{8 - Busca_Contexto_int(col, $\leftrightarrow$ regaut).}

A primitiva Busca_Contexto_int, tem como função buscar o contexto da colônia col, utilizando o regaut como parâmetro de entrada e saída, que é a síntese da autorização das operações de contexto da colônia. 
No passo P1 tem-se a reprodução de regaut numa estrutura auxiliar salvamáscara. Em P2 regaut é alterado de modo a permitir a navegação para a colónia hierarquicamente acima. P3 testa se col é diferente da colónia Global, condicionando o fim da recursão.

No passo P4 regaut é comparado com salvamáscara, utilizando uma analogia com a função lógica "and", ou seja, se campos iguais a 1, então o resultado no subcampo de regaut será 1 , caso contrário, 0.

Em P5, se a colônia ainda não estiver na cópia, então esta será reproduzida juntamente com seu objeto e registro de autorização. Caso contrário P6 apenas alterará o conteúdo ColMod de regaut confrontando-o com ColMod de salvamáscara.

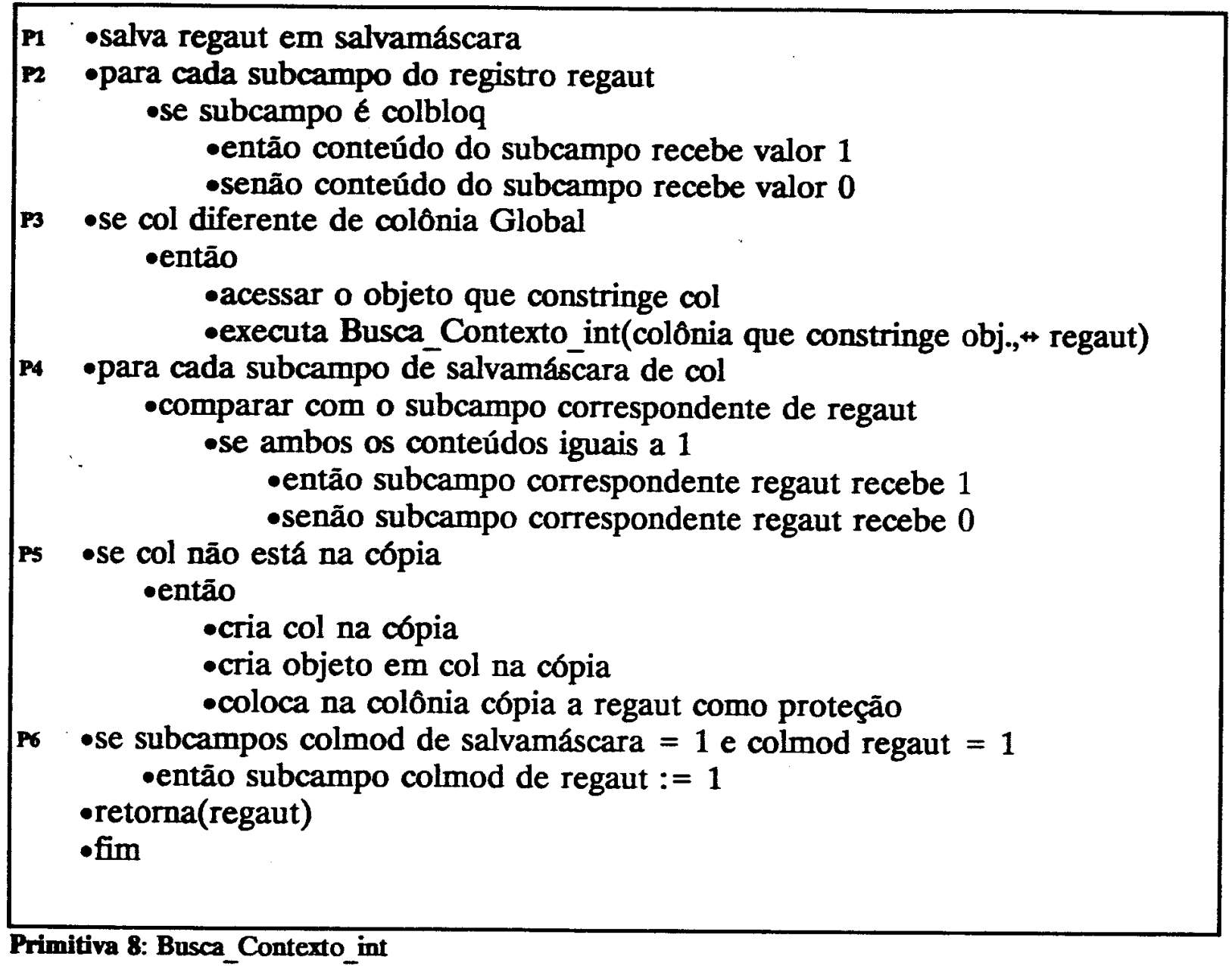

\subsection{2 - Processo de Manipulação.}

$\mathrm{Na}$ fase de manipulação, todas as operaçōes estão limitadas àquelas permitidas pelo registro de autorização de cada colônia em questão. 
A única operação adicional que o processamento de manipulação normal da base deve realizar em função da distribuição, consiste em fazer com que cada objeto velho apagado na base cópia, seja registrado na tabela de objetos apagados da colónia que constringe tal objeto, para que no processo de integração, a primitiva Apaga_Objeto possa acessar essa tabela, e realizar as devidas atualizaçōes na base original.

\subsection{3 - Processo de Integração.}

O processo de integração dependerá da configuração do registro de autorização no momento da separação da base MRO. Para cada configuração deverá existir um processo que seja capaz de integrar a cópia com a versão original, levando-se em consideração as alteraçōes ocorridas tanto na base original quanto na cópia.

Como a separação foi especificada através do conjunto de subcampos do registro de autorização, a análise para a integração também será feita em função desses subcampos.

Nesta subseção, para cada configuraçāo de um subcampo, busca-se especificar primitivas para o tratamento de objetos, atributos, relacionamentos e colônias com suas respectivas operaçōes autorizadas: cria, apaga ou modifica.

A figura 5.13 mostra resumidamente as configuraçōes possíveis geradas na separação e paralelamente, a análise da existência ou não do processo de integração. Conforme mostra esta figura, existem seis configuraçōes.

Na primeira configuração tem-se apenas leitura (r-), onde não ocorre o processo de integração, pois tanto a cópia como a original não evoluiram. Portanto não tem sentido integrar colônias que permaneceram inalteradas.

$\mathrm{Na}$ segunda, tem-se o tipo flagrante (fl) com os valores 1 e 0 para original e cópia respectivamente. $O$ processo de integração também nāo ocorre neste caso, pois apenas a versão original sofreu alteraçōes, enquanto a cópia permaneceu inalterada.

$\mathrm{Na}$ configuração três, como o tipo de ligação entre a cópia e a versão original é independente (in), e portanto tanto a cópia como a original puderam evoluir independentemente, é necessário um conjunto de primitivas capaz de tratar as possíveis operações (cria, apaga ou modifica) sobre objetos, relacionamentos, atributos e colônias. Nesta configuraçāo utiliza-se uma notação para apresentar as primitivas a serem especificadas. No caso de objetos, tem-se: P3OC e P3OA, que significam Primitiva da 


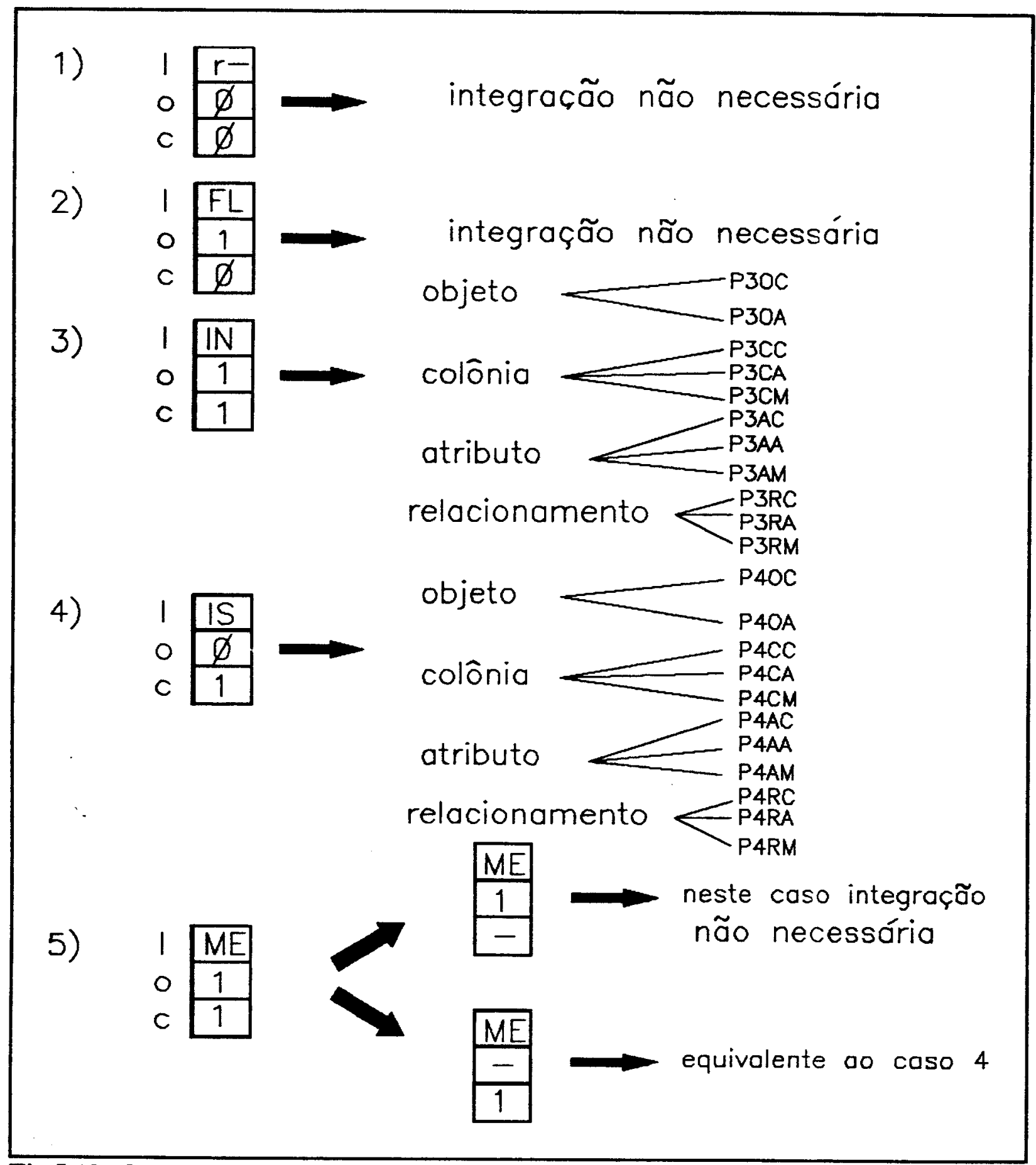

Fig.5.13: Operaçāo Integração para cada tipo de ligação.

configuraçāo 3 para integração de Objetos Criados, ou Objetos Apagados. A notação é análoga para Atributos, Relacionamentos e Colônias incluindo a operaçāo Modifica.

Na quarta, onde o tipo de ligação é isolada (is), permitindo assim a evolução da cópia, enquanto a versão original não pode sofrer alteraçōes, também é necessário especificar as primitivas para a integração das alteraçōes ocorridas na cópia para serem incorporadas a versão original. Utilizando a mesma notação da configuração 3 têm-se 
as primitivas P4OC, P4OA, ....,P4RM, que devem também ser especificadas.

$\mathrm{Na}$ última configuração, onde tem-se a ligação mutuamente exclusiva (me), é possível duas situaçōes:

a) a versão original é eleita para que a base a assuma como única. Neste caso, a integração resume-se em desconsiderar a copia;

b) a versão cópia é eleita para ser a única da base. A integraçāo deverá desconsiderar a versão original e copiar integralmente a versão cópia, tornando-a original. Esta situaçāo é análoga ao caso 4.

Após esta análise constata-se que é necessário especificar as primitivas apenas para integração das configuraçōes 3 e 4.

Ao especificar-se as primitivas de integração para as configuraçōes 3 e 4, verificou-se que era possível generalizar um conjunto de primitivas que fosse capaz de atender às duas configurações mencionadas. Portanto ao invés de especificar as 22 primitivas foi possível restringir-se a apenas 11. O princípio básico consiste em considerar que a integração da configuração quatro é um subconjunto da integração da configuração 3 . A integração onde a cópia evolui e a versão original não (is), pode ser análogo a uma situação em que a cópia e a versão original podem evoluir (in), entretanto apenas a cópia sofreu alteraçōes. Para haver esta generalização de primitivas é necessário que os objetos copiados sejam marcados como velhos na versão cópia.

Este modo de marcar objetos [SEGEV_89], não é necessário no caso onde o tipo de ligação entre a cópia e a versão original é isolada. Para saber se o objeto que está na cópia é novo ou não, basta uma comparação com a base original que permaneceu "congelada" durante o processo de distribuição. Para cada objeto da cópia, se nāo existir um correspondente na base original, então tal objeto foi criado durante a fase de manipulação do processo de distribuição.

Entretanto para o tipo de ligação independente, como a base cópia e a original podem evoluir de modo independente, a maneira de verificar se um objeto é velho ou novo descrito no parágrafo anterior, torna-se inoperante. No momento da separação, o conjunto de objetos na base original será possivelmente distinto do conjunto no momento do processo de integração. Portanto a base cópia deve ter a informação de que os objetos reproduzidos no instante do processo de separação, são considerados velhos. Dessa maneira, para cada processo de separação a base cópia leva a informação do "estado" da base original.

Para efeito de generalizaçāo, as primitivas apresentadas neste capítulo 
pressupōem que a base cópia gerada, terá seus objetos marcados como velhos.

$O$ processo de integração com o tipo de ligação independente dificilmente pode ser tratado automaticamente pelo processo de distribuição, em função dos vários significados que tal processo pode assumir.

No caso do experimento de aprisionamento de átomos descrito na seção 4.5, integrar a base cópia para a base original tem um siginificado de comparação entre as bases. Quando uma base representa o desenvolvimento de um projeto que é subdividido em vários subprojetos, a integração significa uma composição da base.

Portanto a operação de distribuição do MRO fornece ferramentas para tratar bases com evoluções independentes, entretanto o significado de tal integração ficará sob a responsabilidade do usuário.

O tipo de ligação independente também traz um outro inconveniente que $\varepsilon$ a não serialização do processo de integraçāo. A alteração na ordem das bases a serem integradas normalmente traz resultados semânticos distintos. Dessa maneira, o processo de integração não é atômico.

No caso dos tipos de ligações isolada(is) e mutuamente exclusivo (me), o processo de integração pode ser serializado, pois na medida em que uma das bases é liberada apenas para leitura e outra para escrita e leitura, tem-se que tal situação é análoga ao bloqueio em duas fases, onde para processar as transações o dado solicitado é bloqueado e nenhuma outra transação pode acessá-lo.

\subsubsection{1 - Operação_Integração.}

O processo de integraçãc no MRO tem como primitiva principal: Operação_Integração. Esta primitiva tem como objetivo incorporar na base original todas as alteraçōes ocorridas na base cópia.

No passo P1 desta primitiva, o objeto Operaçāo Distribuiçāo constrito pela colónia $\alpha$ é selecionado. Em P2, através de cada relacionamento "composto por" deste objeto, é avaliado o objeto destino do tipo "objeto distribuição". O passo P3 toma cada subcampo do registro de autorizaçāo reg1 desse objeto, que armazena os tipos de ligaçōes, segundo uma ordem pré-estabelecida. No passo P4 tem-se a exclusão do subcampo Colbloc, pois este não está definido para o registro que armazena o tipo de ligação.

Em P5 é avaliado o conteúdo de cada subcampo de reg1 e ainda os conteúdos 
correspondentes de reg2 e reg3. Para cada configuração explicitada é executada a primitiva Integração, que tem como parâmetro o subcampo em questão de reg1. Esta primitiva é descrita logo a seguir, onde para cada tipo de subcampo é executada a respectiva primitiva para integração.

O passo $\mathrm{P6}$, além de resgatar o valor do registro de autorização da base original, no momento imediatamente anterior ao início do processo de distribuição, apaga o relacionamento "composto por" e o respectivo objeto destino. Aqui considera-se que o registro de autorização de cada colônia da base original não foi alterada durante a fase de manipulação, por operações alheias ao processo de distribuição. Se uma alteração assim ocorreu, neste instante essa operaçāo deve ser refeita.

Finalmente o passo P7, após a execuçāo de todas as primitivas envolvidas no processo de integração, apaga o objeto "operação distribuição" da colônia $\alpha$ e elimina a base cópia, terminando assim a Operação Integraçāo.

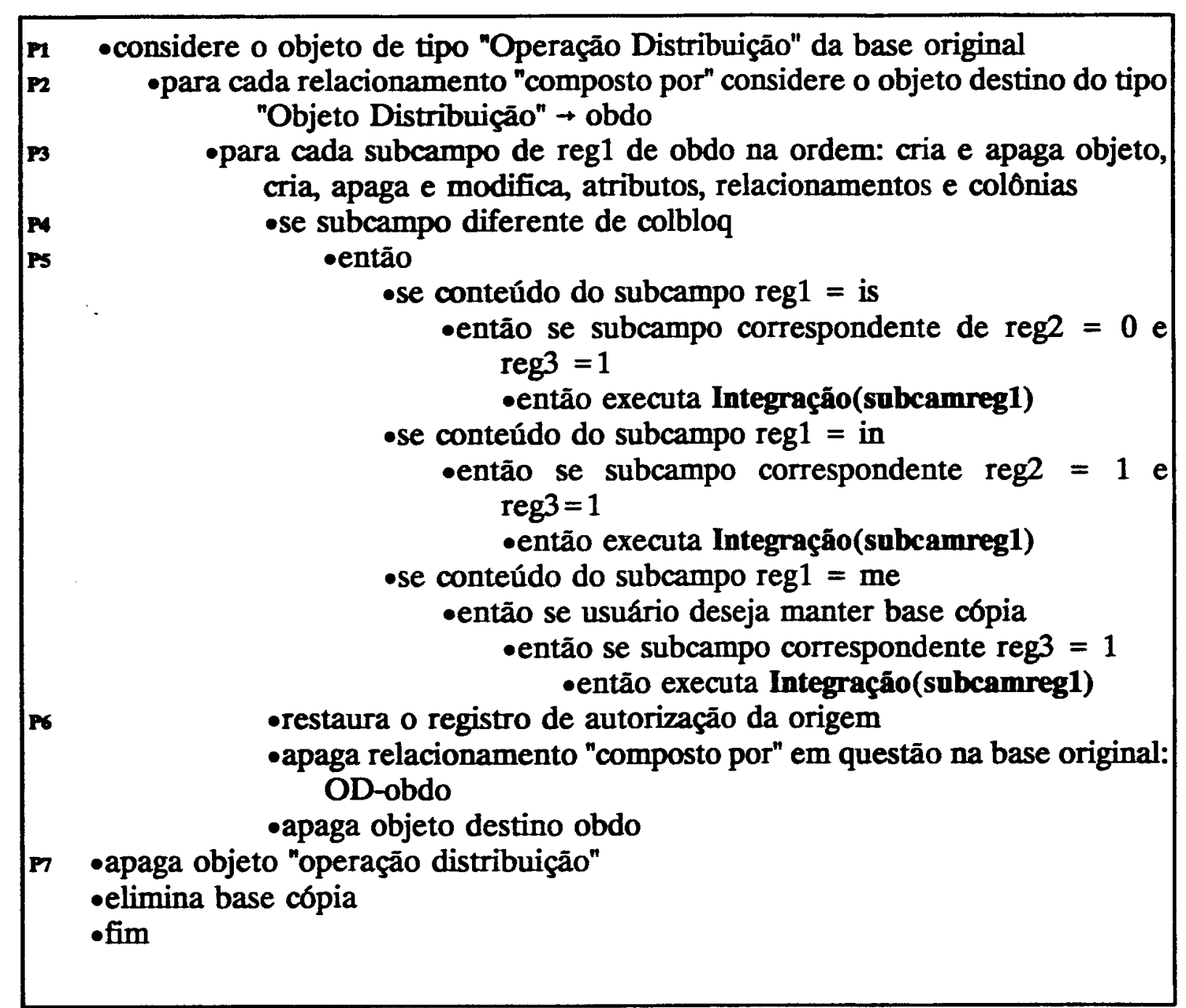

Primitiva 9: Operação_Integração.

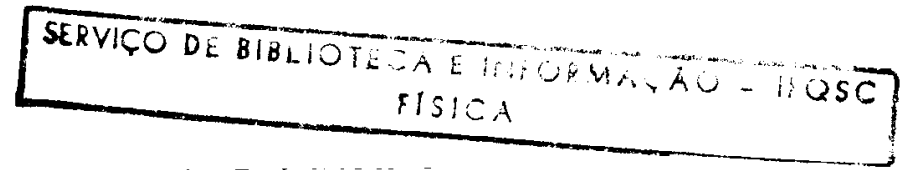


Integraçáo(subcamreg1)

Esta primitiva tem como objetivo executar cada primitiva de integração de acordo com o conteúdo de subcamreg1 passado como parâmetro.

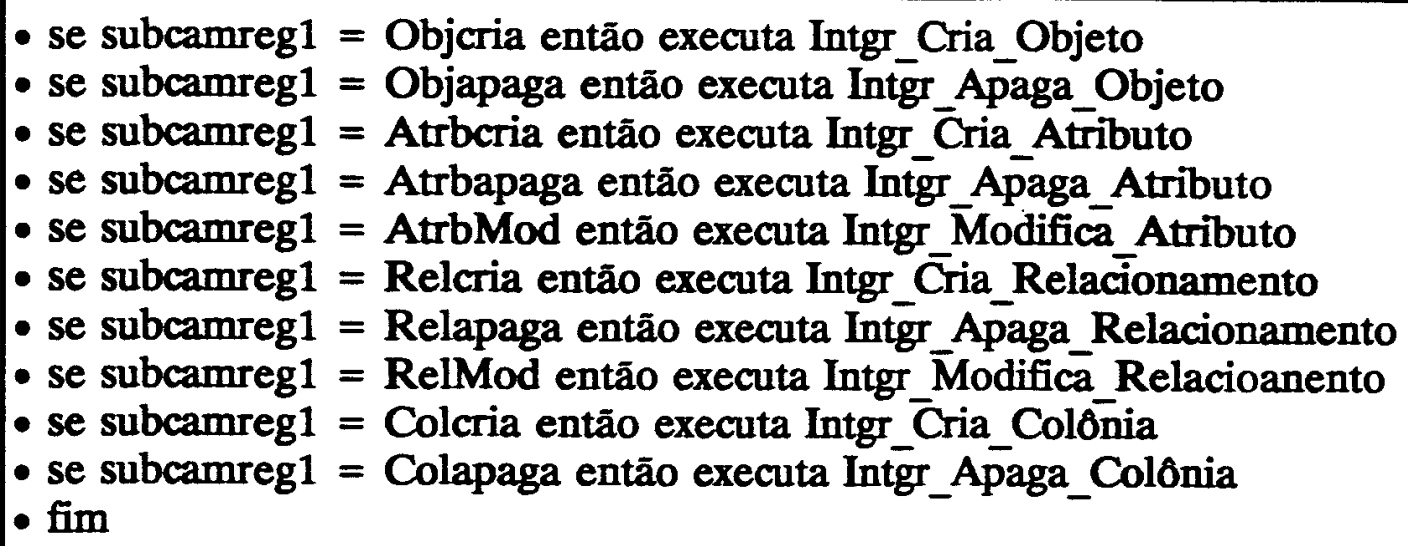

Primitiva 10: Integração.

\subsubsection{2 - Intgr_Cria_Objeto.}

Esta primitiva tem como objetivo avaliar as criaçōes de objetos que ocorreram na cópia e incorporá-los na versão original. No passo P1 tem-se a avaliação do registro de autorização da colônia origem, no que se refere a criar objetos. Se permitido, no passo P2 para cada objeto da colônia cópia deve ser verificado se é "não velho", para que possa ser copiado para a origem. Se for velho, então tal objeto potencialmente já existe na origem. Mesmo que isso não seja verdade, significa apenas que esses objeto foi apagado na cópia original, o que deve ser respeitado. No caso em que esta primitiva estiver integrando colônias através do tipo de ligação independente pode ocorrer que um objeto tenha sido criado tanto na base original quanto na cópia. Nesse caso será considerado que ambos os objetos correspondem a um único se a interseç̧ão dos seus respectivos conjuntos de atributos de idenficadores nāo for vazio. 


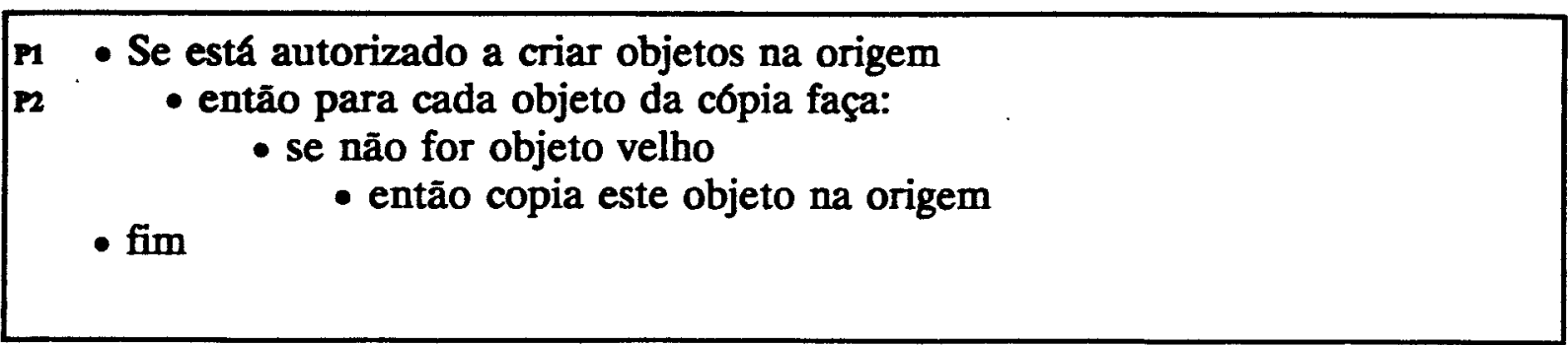

Primitiva 11: Intrg_Cria_Objeto.

\subsubsection{3 - Intgr_Apaga_Objeto.}

A primitiva em questão tem como objetivo avaliar as eliminações de objetos ocorridas na base cópia e atualizar a versão original. No passo $\mathrm{P} 1$, tem-se a avaliação do registro de autorização da colónia origem no que se refere ao subcampo apaga colônia. Se estiver autorizada, P2 percorrerá a tabela de objetos eliminados da base cópia e para cada objeto desta tabela se existir um correspondente na origem, este será apagado. O passo $\mathrm{P} 3$ atualiza a tabela de eliminados da cópia, apagando todos os objetos contidos nesta tabela.

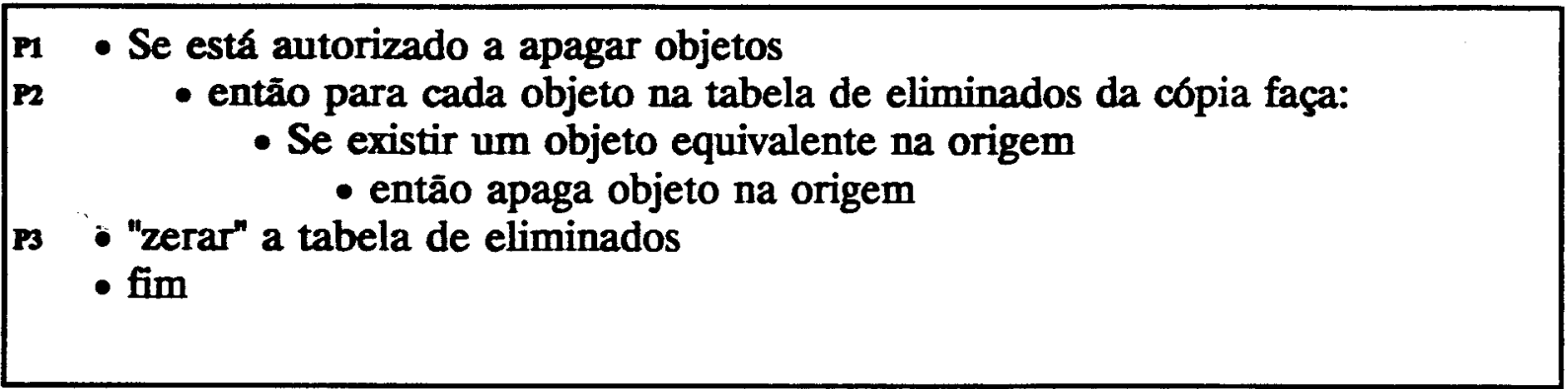

Primitiva 12: Intgr_Apaga_Objeto

\subsubsection{4 - Intgr_Cria_Atributo.}

Esta primitiva avalia os atributos criados na cópia, atualizando a versão original. No passo P1, para cada objeto da colônia cópia, se o objeto não for velho, todos os atributos são copiados para o respectivo objeto origem. Caso contrário, P2 copiará os atributos novos criados nos objetos velhos, se o registro de autorização da colônia origem permitir.

\subsubsection{5 - Intgr_Apaga_Atributo.}




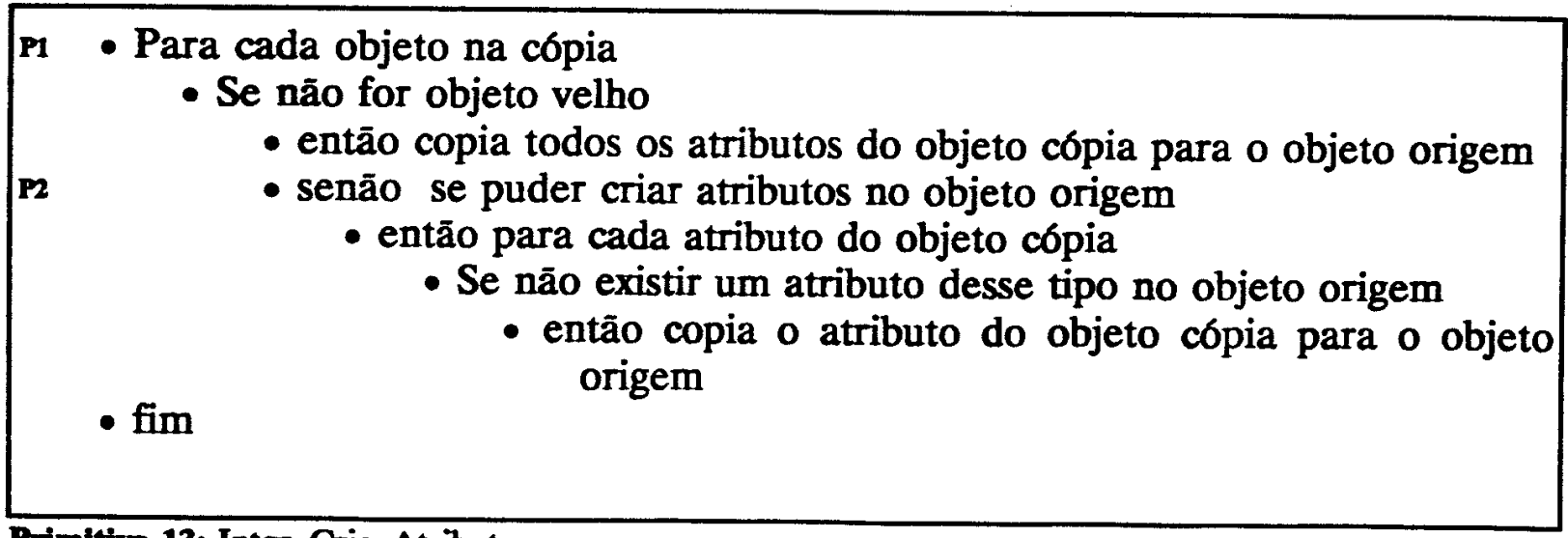

Primitiva 13: Intgr_Cria_Atributo.

Esta primitiva atualiza os objetos da colônia original em função dos atributos dos objetos eliminados na colônia cópia. Em P1 selecionam-se os atributos dos objetos velhos na base cópia. P2 verifica a existência ou nāo deste atributo na base original. Se não existir tal atributo, então deve ser apagado o objeto da base original.

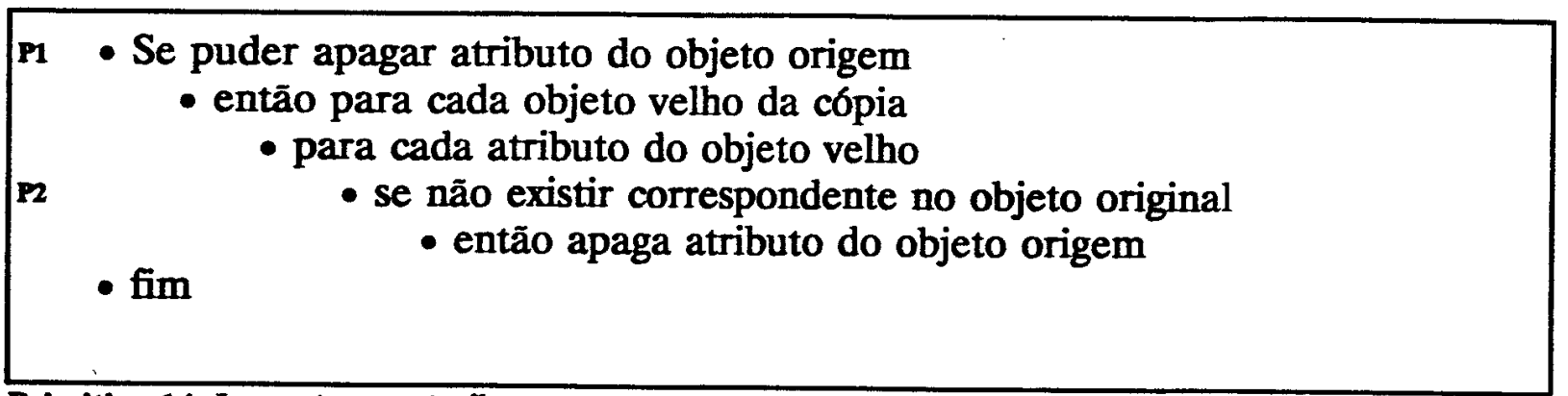

Primitiva 14: Intgr_Apaga_Atributo.

\subsubsection{6 - Intgr_Modifica_Atributo.}

Esta primitiva incorpora as alteraçōes ocorridas nos atributos dos objetos da cópia para a origem. P1 seleciona o atributo e avalia, através do registro de autorizaçāo, se é permitido alterar atributo. Se puder alterar atributo, P2 atualiza os atributos monovalorados e P3 os atributos multivalorados, apagando os atributos da origem e reproduzindo os atributos da cópia.

\subsubsection{7 - Intgr_Cria_Relacionamento.}

Esta primitiva tem como objetivo incorporar os relacionamentos criados na base 


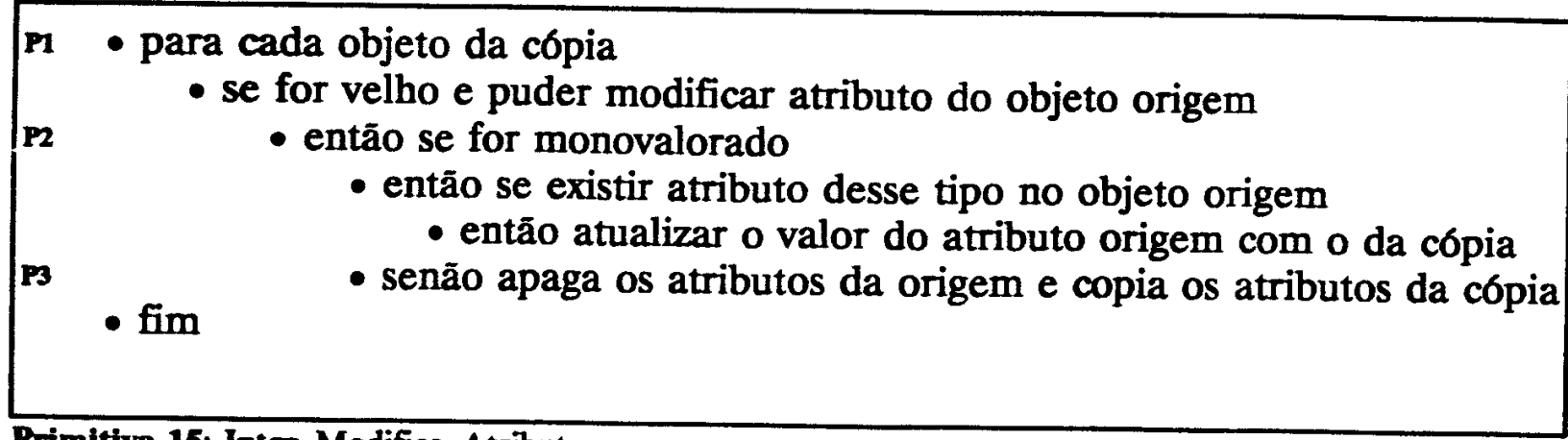

Primitiva 15: Intgr_Modifica_Atributo.

cópia para a base original. No passo P1 tem-se a seleção do relacionamento do objeto não velho que deve ser reproduzido na base origem. Se o objeto destino for não velho, então $P 2$ deve reproduzir este relacionamento com seus atributos para a base origem se o registro de autorização permitir, quer este relacionamento seja de interface ou de conteúdo. P3 copia relacionamento com seus atributos, se for permitido, na base origem se objeto destino for velho.

O passo P4 trata os relacionamentos de objetos velhos, criados na base cópia, reproduzindo os relacionamentos com seus atributos, se for permitida a criação de relacionamentos, na base origem tanto no caso de relacionamento de interface ou de conteúdo.

\subsubsection{8 - Intgr_Apaga_Relacionamento.}

Esta primitiva tem como objetivo atualizar a base original no que se refere aos relacionamentos apagados na base cópia. No passo P1 tem-se o teste da permissão para apagar relacionamentos. Se possível há a seleção do objeto velho da base cópia para a avaliação de seus relacionamentos. Em P2 para cada relacionamento do objeto na base original, se não existir um relacionamento correspondente na base cópia, então o relacionamento da base origem deve ser apagado.

\subsection{9 - Intgr_Modifica_Relacionamento.}

Esta primitiva tem como objetivo incorporar as alterações dos atributos dos relacionamentos da base cópia para a base original. No passo P1 tem-se a seleção do 


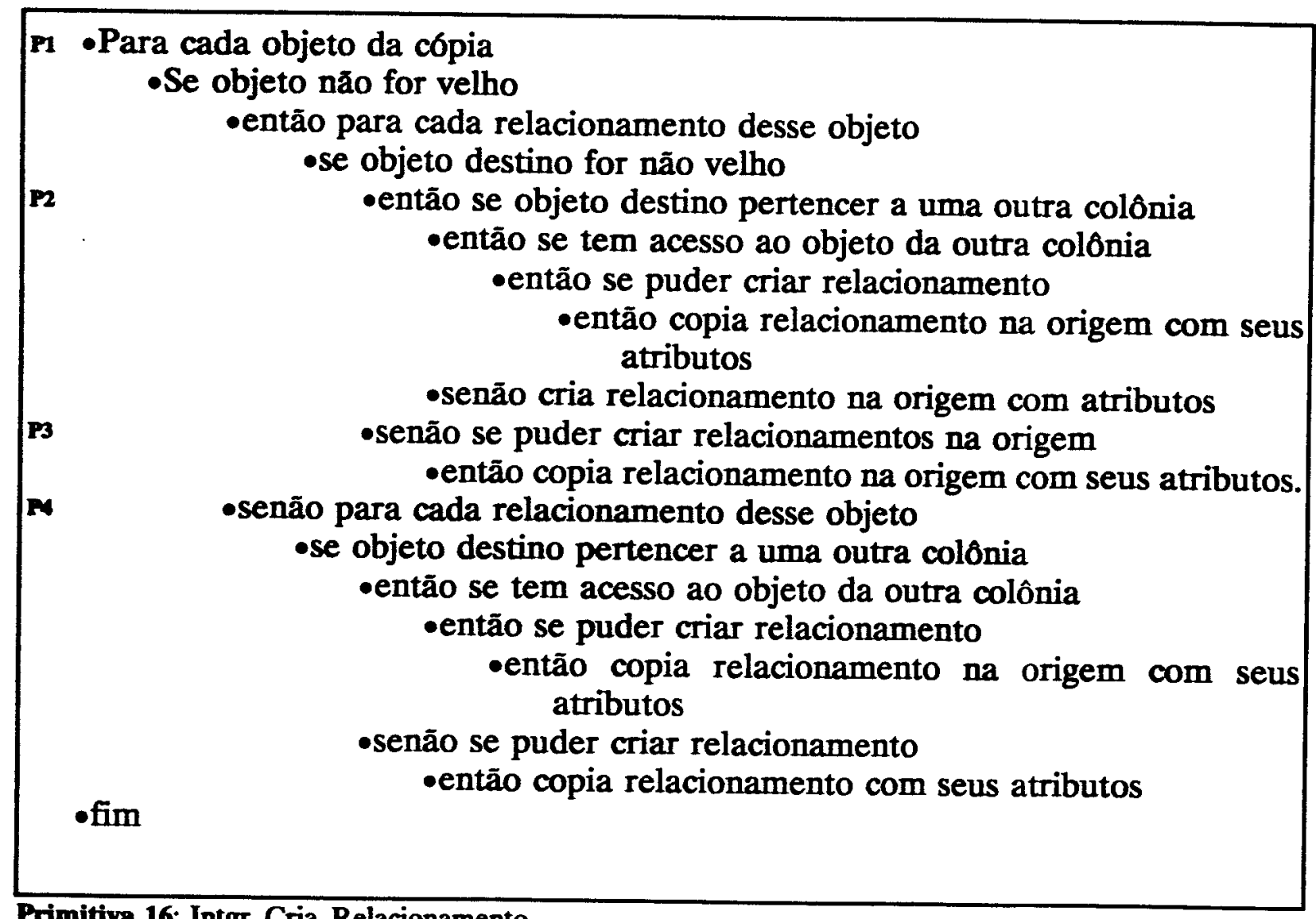

Primitiva 16: Intgr_Cria_Relacionamento.

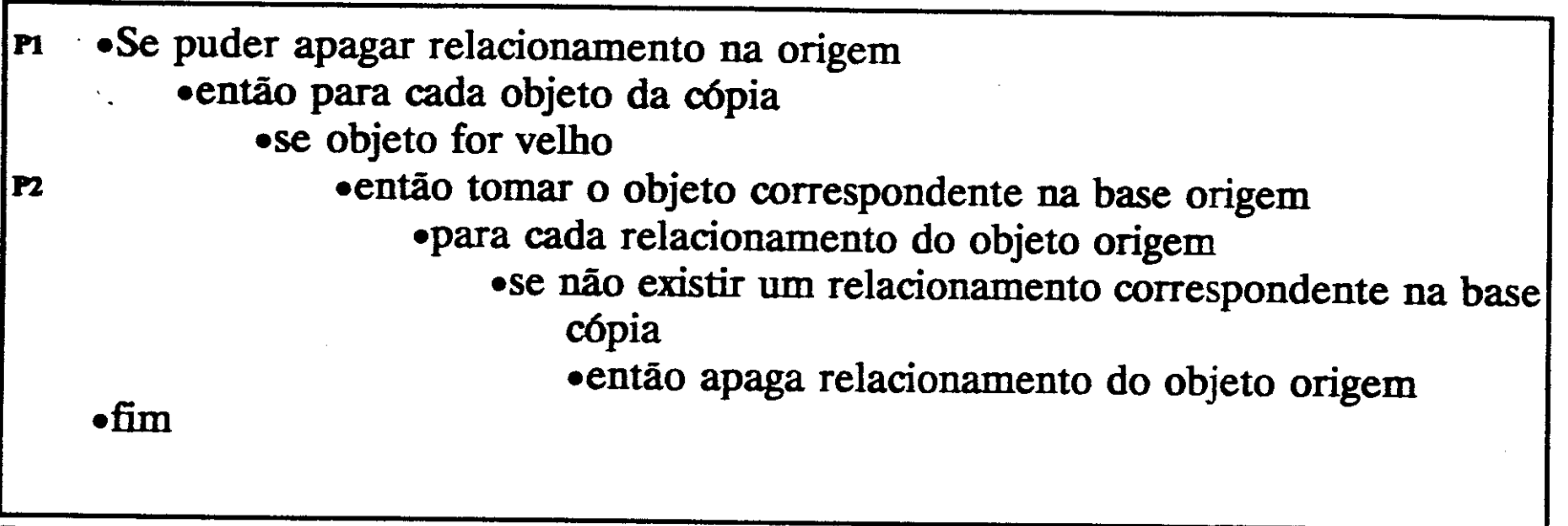

Primitiva 17: Intgr_Apaga_Relacionamento.

relacionamento que possivelmente sofreu alteraçōes. Em P2 é testado se o relacionamento é de interface ou de conteúdo. Se for de interface, ainda no passo P2 é avaliado se o objeto destino pode ser acessado. Se puder, P3 executa a primitiva IntgrCopia_Atributo. Se relacionamento for de conteúdo então P4 executa Intgr_Copia_Atributo. A primitiva executada nos passos P3 e P4 tem como parâmetro o relacionamento(rel), cujo os atributos possivelmente foram alterados na base cópia. 


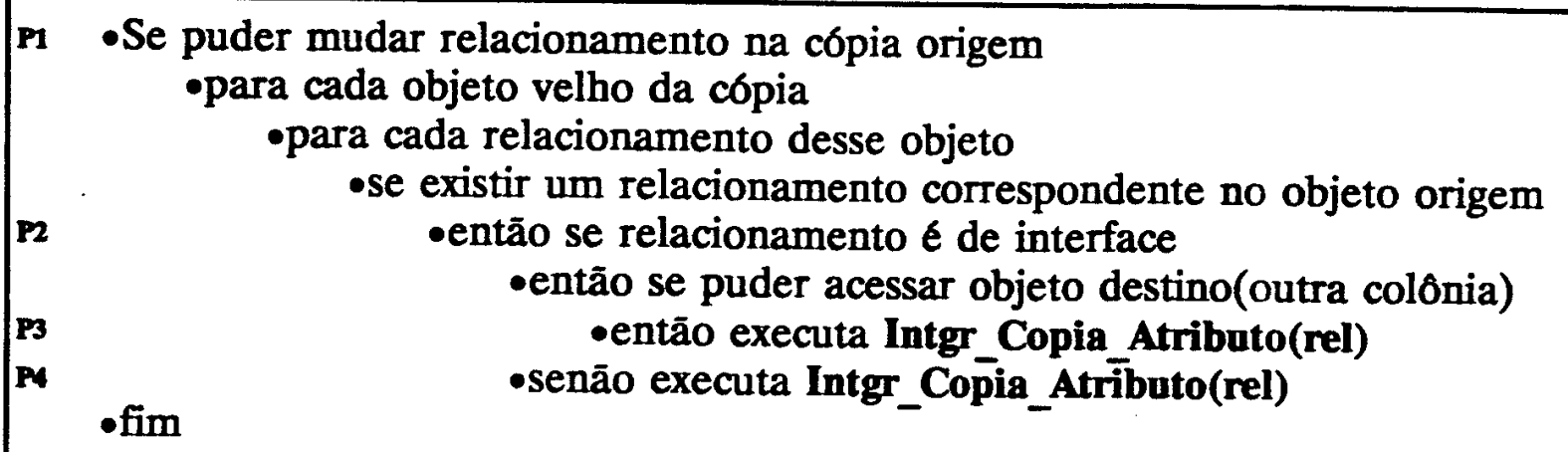

Primitiva 18: Intgr_Modifica_Relacionamento.

\section{Intgr_Copia_Atributo(rel)}

Esta primitiva copia os atributos alterados na base copia para a base original. No passo P1 tem-se a seleção do atributo a ser avaliado e ainda o teste se tal atributo é de relacionamento triplo ou não. Se não for de relacionamento triplo, P2 avalia as autorizações para criar, apagar ou modificar atributos e a existência do referido atributo na origem para poder atualizar a base origem $O$ passo $P 3$, se o relacionamento for triplo, reproduz da base cópia para origem o relacionamento em questão. Para isso é necessário que todos os relacionamentos binários que compõem o triplo sejam copiados previamente. 


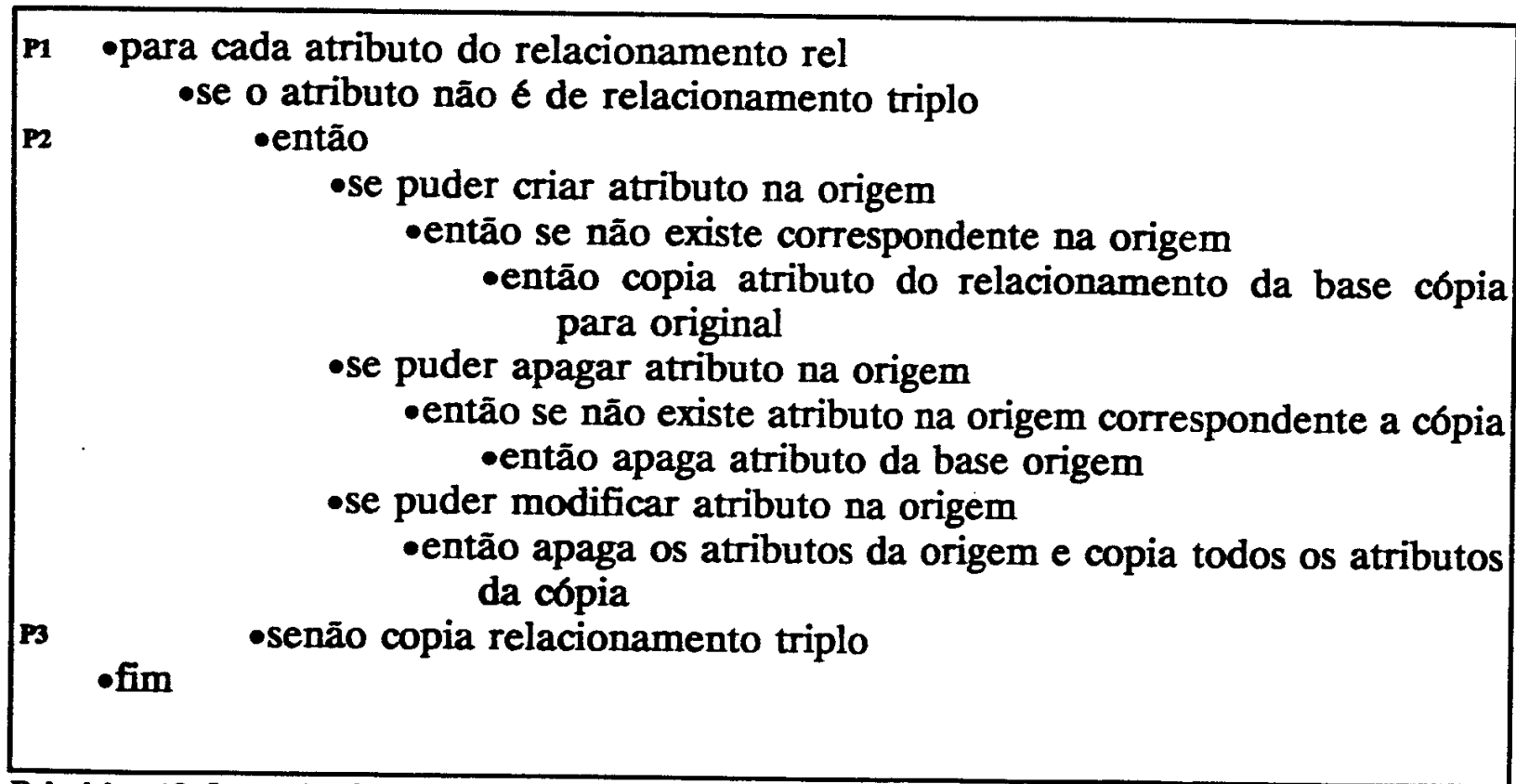

Primitiva 19: Intgr_Copia_Atributo.

\subsubsection{0 - Intgr_Cria_Colônia.}

Esta primitiva tem como objetivo incorporar na base original as colônias criadas na cópia. Em P1 tem-se a seleção da colônia a ser copiada se não existir colônia correspondente na origem. P2 executa a primitiva Intgr_Duplica_Colônia, que tem como parâmentro a colônia(col) em questão.

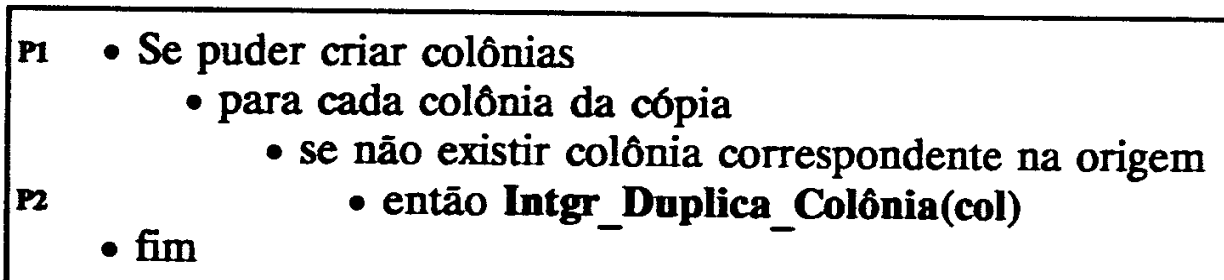

Primitiva 20: Intgr_Cria_Colônia.

Intgr_Duplica_Colônia(qual) 
Esta primitiva, através do passo P1, para cada objeto da colônia cópia, duplica na origem o proprio objeto, seus atributos, e seus relacionamentos. No passo $P 2$, se algum objeto da colônia em questão constringir uma outra colônia, então a primitiva Intgr_Duplica_Colônia será executada tendo como parâmetro a colônia constrita pelo objeto(colconstrita).

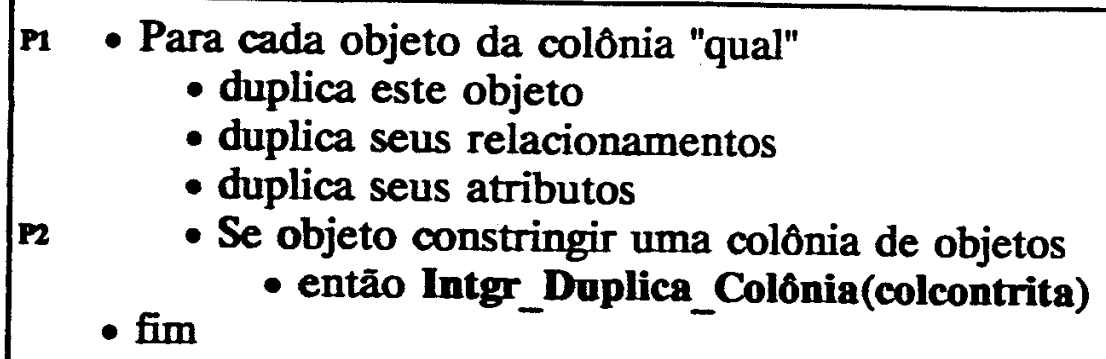

Primitiva 21: Intgr_Duplica_Colônia.

\subsubsection{1 - Intgr_Apaga_Colônia.}

Esta primitiva tem como objetivo verificar as colônias que foram apagadas da cópia e atualizar a versão original. $O$ passo $P 1$ seleciona a colônia que deve ser apagada, através da comparação entre a base original e cópia. Se não existir uma colônia correspondente na cópia, entāo P2 executa a primitiva Intgr_Destrói_Colônia(col) que tem como parâmetro a colônia original.

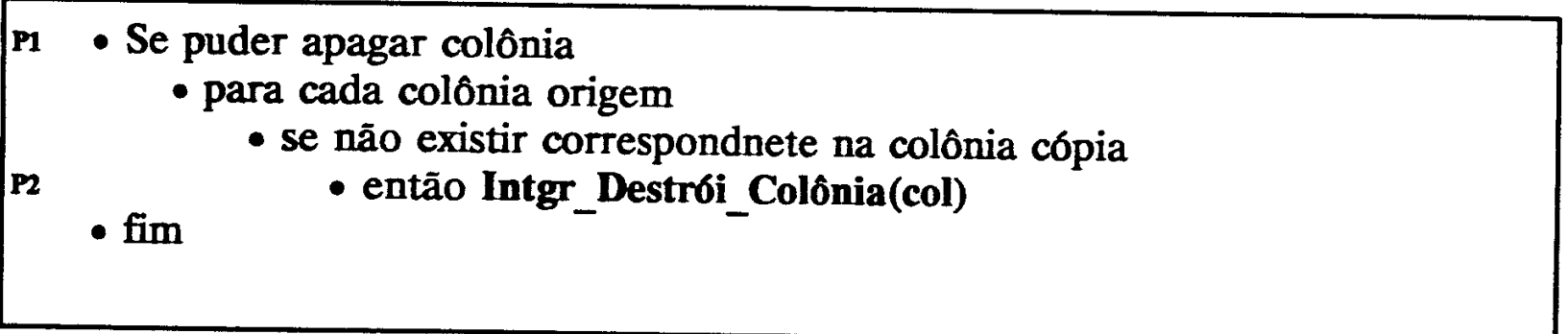

Primitiva 22: Intgr_Apaga_Colônia.

\section{Intgr_Destroi_Colônia(qual)}

Esta primitiva em P1 executa um processo recursivo para cada objeto, até atingir 
a colónia constrita de grau hierárquico mais inferior. P2 apaga os relacionamentos da colônia em questāo e ainda testa a existência ou nāo de algum relacionamento. Se existir algum relacionamento, então o objeto não pode ser apagado e como conseqũência a colónia que o constringe também não. Se todo relacionamento foi apagado, P3 testa a existência de alguma colônia constrita pelo objeto. Se nāo existir então atributos e objetos, estes serão apagados. P4 elimina colônia se não existir objetos constritos.

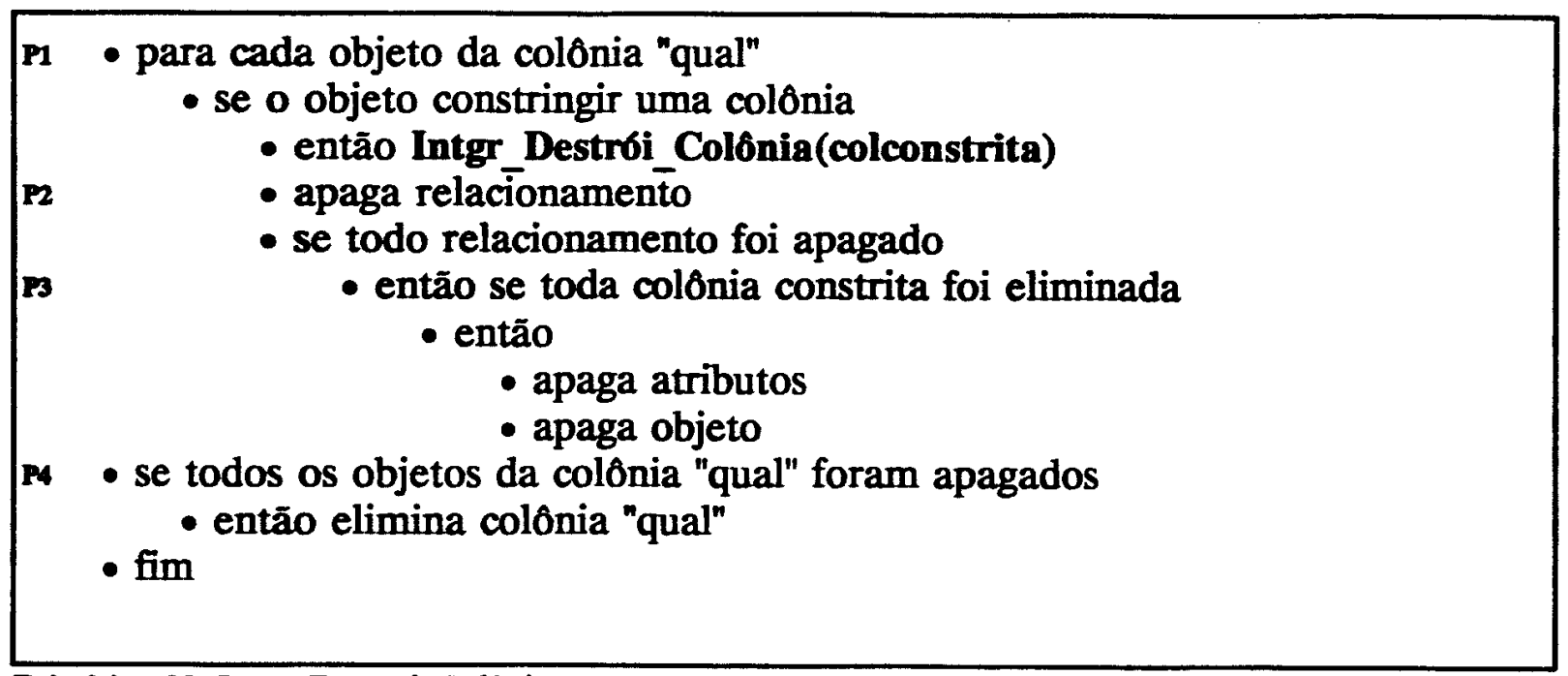

Primittiva 23: Intgr_Destroi_Colônia

\section{4 - Conclusão.}

Neste capítulo apresentou-se uma proposta para a distribuição de uma Base de Dados apoiada no MRO. Caracterizou-se a necessidade de distribuição de maneira distinta das bases de dados convencionais. $O$ tratamento da concorrência dos dados que em uma base convencional distribuída é um dos aspectos mais importantes, no MRO tal tratamento nāo foi abordado em função da especificação de outras necessidades.

A distribuição de dados no MRO foi definida em função do tipo de ligação que a base original estabelece com sua respectiva cópia. A operação de distribuiçāo na base MRO é dividida em três fases: separação, manipulação e integração. Para cada tipo de ligação: $\mathbf{r - ,}$ is, $\mathbf{n}$, me, in, estabelecida na fase de separação, haverá um registro de autorização que deverá ser respeitado pelas operações efetuadas na fase de manipulação. Na fase de integração, para cada configuração dos registros da distribuição, é executado um conjunto de primitivas, cujo objetivo é repassar para a base original as alterações realizadas na base cópia. 
Para efetuar-se a distribuição, além dos registros mostrados na figura 5.8(reg1, reg2, reg3), é necessário especificar o "esquema" da distribuição, alocado na colônia $\alpha$ da base original e cópia, conforme ilustram as figuras 5.9 e 5.10 .

Para que os objetos possam ter significado, cada colónia a ser reproduzida tem necessariamente que "levar" para a base cópia o esquema que a rege e ainda seu contexto.

No processo de separação, cada subcampo do registro de autorização da colônia cópia será avaliado. Em função desta avaliação, o usuário pode definir o tipo de ligaçāo que cada colónia a ser distribuída deve manter entre a base original e sua respectiva copia. Tanto o processo de manipulação quanto de integração dependem da especificação dos registros realizada na fase de separaçāo. As operações realizadas estarão limitadas aos referidos registros. $\mathrm{Na}$ integração, o conjunto de primitivas será executado de acordo com as configuraçōes dos registros para distribuição.

Nos tipos de ligações onde uma base tem apenas operaçōes de leitura e a outra, escrita e leitura, tem-se como conseqũência uma versão não atualizada dos objetos acessados na base onde apenas as operaçōes de leitura estão autorizadas.

Para evitar tal desatualização, a base poderia ser bloqueada através do subcampo colbloq, durante a operação de distribuiçāo. Entretanto num ambiente distribuído, como as transaçōes que envolvem distribuição normalmente são mais demoradas que um acesso local, o intervalo de atividades do sistema aumentaria significativamente.

O fato de permitir a leitura nos tipos de ligações is, me e n, na operação distribuição, tem como objetivo atender as solicitações de leitura da maneira mais rápida possível em detrimento de não ser a versão mais atualizada do objeto solicitado.

A integraçāo de bases que nāo estabeleceram entre si um tipo de ligação na fase de separação será executada em função do registro de autorização de cada base envolvida. Com isto, no processo de integração, as bases serão consideradas como independentes, não havendo o conceito de objeto velho ou novo. Se todos os objetos forem considerados como velhos, os algoritmos para a operação integração, descritos anteriormente, podem ser utilizados na integração de bases que não sofreram previamente um processo de separação. 


\section{Capítulo 6 \\ Decisóes de PROJeTo, Futuras PESQUisas E CONCLUSŌES}

\section{1 - Decisōes de Projeto.}

\subsection{1 - Necessidades de Distribuição em Modelos Convencionais e no MRO.}

No início do trabalho não se conhecia a dimensão do problema da distribuição de uma Base de Dados Orientada a Objetos. Também não se dispunha de uma bibliografia capaz de apresentar os principais problemas a serem abordados no momento em que se deseja realizar uma distribuição. $O$ objetivo, desde o início, foi criar um modelo funcional e lógico para que se pudesse atender às necessidades de distribuiçăo num ambiente de projetos.

Como não se conhecia de antemão os problemas a serem enfrentados, passou-se a estudar o modelo de distribuição de Bases de Dados Convencionais, de modo específico os sistemas de bases de dados apoiados no modelo relacional. O objetivo deste estudo foi de caracterizar não só os conceitos envolvidos, mas também as necessidades de distribuição atendidas pelo modelo.

Pode-se destacar que a "coexistência" dos dados para todos os nós envolvidos na distribuição é a necessidade principal que o modelo de distribuição de Base de Dados para as aplicaçōes convencionais busca atender.

Esta coexistência dos dados traz algumas conseqüências que devem ser tratadas pelo sistema de Gerenciamento de Base de Dados: controle de concorrência e controle de integridade.

$\mathrm{Na}$ medida em que os dados coexistem, diversas transações poderão tentar acessá-los "ao mesmo tempo". A concorrência das transações pelos dados é tratada nos 
modelos de Base de Dados convencionais através de dois métodos: bloqueio e préordenação. $O$ primeiro se caracteriza pelo fato de que a ordem das operaçōes é conhecida após as transaçōes serem efetuadas. Já o método de pré-ordeuação, que utiliza o conceito de "timestamp", tem a ordem estabelecida antes das transações se efetivarem.

$\mathrm{Na}$ ocorrência de falhas indesejáveis, entretanto possíveis, estruturas "robustas" são definidas com o objetivo de atenuar o efeito das referidas falhas. Atas, Imagens Transientes, Descarga, Arquivos Diferenciais, Programas Restauradores, são estruturas utilizadas para prever e/ou recompor o sistema na ocorrência de falhas.

Diante dos aspectos levantados, com o estudo da distribuiçāo das Bases de Dados Convencionais, passou-se ao estudo das possiveis necessidades de distribuição para um ambiente de desenvolvimento de projetos. Entretanto, numa primeira análise, chegou-se à conclusão que era necessário aprofundar-se nos conceitos do Modelo de Representação de Objetos e nos aspectos de implementação do modelo em questão.

Como síntese desse estudo verificou-se que as necessidades de distribuição num ambiente para desenvolvimento de projetos são distintas daquelas impostas pelas aplicaçōes convencionais, e são mais facilmente suportadas pelo MRO.

Uma característica muito importante num ambiente de desenvolvimento de projetos é o fato de tanto a cópia quanto a base original poderem evoluir independentemente, ou então apenas uma evoluir mas manter liberadas as operações de leitura nas demais cópias. Após um determinado tempo, estas bases cópia e original, podem sofrer um processo de re-integração, o qual síntetiza as operações ocorridas tanto na cópia quanto na original.

Com isto algumas características importantes em aplicações convencionais tal como a atomicidade e a serializabilidade passam a não ter grande relevância na especificação de um ambiente distribuído voltado ao desenvolvimento de projetos, enquanto outras necessidades precisam ser atendidas pelo sistema distribuído.

\subsection{2 - Definição dos tipos de ligação entre bases original e cópia.}

Foram definidos os registros de autorizaçōes para a distribuiçāo do MRO para objetos, colônias, relacionamentos e atributos, conforme ilustra a figura 5.8 e ainda $\mathrm{o}$ esquema do modelo de distribuição ilustrado através das figuras 5.9 e 5.10. 
Inicialmente pensou-se em considerar como "máscara" para separaçāo da Base de Dados MRO, todos os registros(fig. 5.8) que contêm a especificação das autorizaçōes das operações e também o tipo de ligação entre a colônia original e a cópia.

Este caminho levou a especificação dos registros que continham todos os onze campos referentes às operações para criar, apagar ou modificar objetos, relacionamentos, atributos e colônia como uma única configuraçāo, e os respectivos registros de autorizaçōes da original(O) e cópia(C).

Com isto surgiu a visualização de apenas três modos básicos para os tipos de acesso: apenas leitura(r-), independente(in), exclusivo(ex), e um quarto modo que era a combinação dos anteriores. Por r-, entendia-se apenas as operações de leitura liberadas para original e cópia. Independente, pressupunha-se que tanto a base original como a copia podiam evoluir de modo independente. Exclusivo, entendiam-se todas as operações liberadas para cópia e apenas leitura para versão oficial.

Entretanto quando começou-se a pensar nos possíveis passos para a integração, essa forma para especificar a separação mostrou-se ineficiente, pois conduzia a caminhos que dificultavam a compreensão e solução do problema.

Basicamente este processo induzia a dois tipos de erros que impossibilitavam a condução do raciocínio para compreensão do problema real e conseqūentemente a soluçāo real para a Distribuiçāo do MRO.

Primeiro: o fato de agrupar todas as operaçōes para criar, apagar ou modificar objetos, colônias, relacionamentos e atributos, induzia a consideraçāo de que estes subcampos, que formavam campos e conseqüentemente registros, estavam vinculados entre si. Na verdade cada subcampo tem uma especificação independente. Esta constatação implicou na conclusão de que as operações sobre objetos, colônias, atributos e relacionamentos devem ser realizadas de modo independente para a operação de distribuição. Com isto, a análise passon a recair sobre o subcampo, o que simplificou muito a representação das possibilidades de separação. A figura 5.11 ilustra tal situação.

Segundo: Como o registro da forma de operação de distribuiçāo apresenta-se juntamente com as autorizações de r- e rw para a versão original e a cópia, induziu-se a pensar que, para decidir sobre as características de uma operação de distribuição centrada num objeto que foi gerado por uma outra operaçāo de distribuição, dever-se-ia analisar as formas permitidas para acesso (r-, independente e exclusivo) levando em consideração as autorizações da original e cópia. Isto também não era verdade, pois o 
que interessa para a operaçáo de distribuição é apenas autorizaçóes de r- ou rw sobre as operaçōes de criar, apagar ou modificar.

Diante destas duas considerações, destacadas através do negrito, passou-se a reavaliar o problema, onde constatou-se que ao invés de três tipos de ligação e uma combinação para a distribuição, tem-se na verdade cinco tipos de ligação e combinação das mesmas, sendo que um desses tipos é dividido em dois subtipos.

Cabe observar que a configuração anteriormente denominada exclusivo, passou a se chamar isolado. Nota-se ainda o surgimento de mais dois tipos de ligaçāo: um tipo chamado mutuamente exclusivo(me) que representa a situação onde tanto a cópia como a original podem evoluir independentemente, entretanto quando solicitar a integração, apenas uma deverá ser assumida; o outro, flagrante(f) onde apenas a original pode evoluir enquanto apenas operações de leitura são permitidas na cópia. Esses tipos de ligação foram definidos segundo as diferentes necessidades da operação distribuída em um ambiente de projeto.

\subsection{3 - Diferenciação de Objetos da Base Cópia.}

Para diferenciar os objetos reproduzidos na cópia através da operação de separação, dos objetos criados, apagados ou modificados na cópia, utilizou-se a marcação de objetos "velhos". O mesmo procedimento poderia ser feito para relacionamentos e atributos. Entretanto dado o grande tamanho da estrutura de dados necessária para controlar tal proposta, a operação de distribuição tornar-se-ia excessivamente "carregada", inviabilizando a eficiência da Base de Dados Distribuída. Assim, considerando-se que toda a identificação de dados é feita por objetos, e que com isso pode-se efetuar qualquer correspondência entre a informação manipulada externamente a base, $\mathrm{e}$ as estruturas armazenadas, optou-se por garantir o reconhecimento do que é velho e do que é novo apenas a nível de objetos, deixando-se para atributos uma estrutura que, embora permita a ocorrência de conflito ou sobreposiçāo de dados, é possível ter os resultados controlados a nível da própria aplicação. Assim em situaçōes críticas, um aplicativo pode assumir o controle da replicação e re-integração de atributos, e em situações gerais prevalece o critério de que a última operação de integração efetuada tem precedência para a determinaçāo dos valores armazenados. 


\subsection{4 - Relacionamento de Interface.}

O tratamento de relacionamentos que acessam objetos pertencentes a outras colônias(rel.interface) também foi padronizado conforme ilustra a figura 5.12. Definiu-se uma sintaxe para o relacionamento de interface no que se refere aos acessos permitidos a objetos, relacionamentos e atributos. Com isto, no processo de separação da base original, se a colónia na qual habita o objeto destino for acessada por um relacionamento de interface:

- se tal colônia permitir as operaçōes de escrita e leitura então a base cópia poderá criar, apagar ou modificar o relacionamento de interface;

- se permitir apenas leitura, então o objeto só pode ser acessado juntamente com seus atributos mas nada pode ser alterado;

- e finalmente se a colônia estiver bloqueada então nem o objeto destino pode ser acessado, embora se reconheça a sua existência.

Com isso as operações de acesso a colônias nāo distribuídas, que no entanto constringem objetos destino de relacionamentos distribúdos, são garantidas e controladas.

\subsection{5 - Relacionamento Triplo.}

Para a reproduçāo de um relacionamento triplo, restringiu-se a análise do processo de separação e de integraçāo ao conceito que um relacionamento triplo é conceitualmente um relacionamento binário entre o objeto da Divivisão1 e o objeto da Divisão3, que tem como atributos os relacionamentos binários entre o objeto da Divisão1 e os da Divisão2. Assim as considerações efetuadas sobre relacionamento de interface ou de contexto, valem da mesma maneira para os binários componentes da tripla. Isto resulta que um relacionamento triplo: ou é de contexto se todos os binários componentes são de contexto; ou de interface, se ao menos um dos binários for de interface. A solução adotada nas primitivas leva em conta que a separação ou integração de relacionamentos triplos é feita posteriormente às operações de separação ou integração dos relacionamentos binários, incluindo-se aqui os relacionamentos binários que são componentes de relacionamentos triplos, o que está de acordo com tal conceito. 


\section{2 - Futuras Pesquisas.}

\subsection{1 - Semânticas de Integração.}

A Operação de Integração, que é executada em função da configuração dos subcampos gerados na operação de separação, na qual o tipo de ligação é independente, tem na sua operaçāo de integração uma semântica específica para cada situação da base cópia e original. Como foi mencionado na seção 5.4, a composição e a comparaçāo são algumas das possíveis consequências da operação de integração. Provavelmente existem outras que poderão ser tratadas de modo a especificar uma semântica para o tipo de ligação independente. Qualquer que seja a especificação, a incorporação deste, nas primitivas propostas por este trabalho, não acarretá muitas complicações, na medida em que as primitivas tratam os problemas da distribuição, de modo bastante localizado. Tal como as primitivas estão descritas, elas suportam a semântica de composição. Alterá-las para atender a outras semânticas é uma tarefa que requer fundamentalmente a identificação das operações correspondentes, e a parametrização adequada das primitivas já descritas. Como sugestāo de futuras pesquisas, considera-se a análise da semântica de comparação e um estudo de um conjunto mais abrangente de semânticas de integração.

\subsection{2 - Novos tipos de Integração.}

A operaçāo de integração onde não ocorre previamente uma operação de separação pode trazer significados análogos ao processo de integração onde está caracterizado o tipo de ligação independente. É possível neste caso estudar a semântica envolvida na operação em questão, especificando-a. Esta especificação também poderia ser incorporada, sem muitas dificuldades, nas primitivas para integraçāo apresentadas neste trabalho. Igualmente, é possível estudar a situação onde uma operação de integração não elimina a base cópia, permitindo re-integraçōes parciais de uma cópia ainda não plenamente projetada. Como sugestão de futuras pesquisas, considera-se o estudo de integrações sem a ocorrência da operação de separação e a integração de 
bases sem a eliminação da base cópia.

\subsection{3 - Controle de Integridade na Operação de Integração.}

Na operaçāo de integração pode existir um número muito grande de integraçōes de objetos que não puderam ser realizadas, pois no instante da integração algumas colonias poderiam estar bloqueadas. Para minimizar este problema, poderiam ser utilizadas estruturas robustas que armazenariam as integraçōes que não puderam se efetivar. Estas estruturas poderiam atender não só as integraçōes que não puderam ser realizadas pelo fato de encontrar colônias bloqueadas, como também atender as possíveis falhas ocorridas no sistema. Para se ter uma visualização da situação de conflito da base de dados, poderia ser elaborado um aplicativo que fornecesse o "estado" de conflito da base. Além disso, é importante que na implementação efetiva das primitivas efetuadas, sejam gerados "relatórios" para os usuários, descrevendo como ocorrem aspectos importantes da integração e da separacão, tal como conflito entre relacionamentos, repetiçāo de identificadores. Um outro recurso que pode ser adicionado para o tratamento de conflitos é a interferência do usuário para a soluçāo de conflitos que por algum motivo não puderam ser solucionados pelos procedimentos anteriores. Portanto, como futuras pesquisas considera-se: especificacão de estruturas robustàs para o tratamento de falhas e integraçōes incompletas; geração de relatórios que descrevem os resultados da operação distribuição; especificação de uma interface com usuário para solucionar os possíveis conflitos na operação de distribuição.

\subsection{4 - Tipo de Ligação "Online".}

Um sistema distribuído para um ambiente "online", onde qualquer alteração em uma determinada cópia seja repassada imediatamente para sua respectiva base original ou então para outras cópias, pode ser atendido pelo sistema de distribuição do MRO através da criação de um sexto tipo de ligação, que pode ser incorporado ao núcleo básico de primitivas apresentadas neste trabalho. Como futuras pesquisas considera-se o estudo de um novo tipo de ligação para um ambiente "online". 


\section{3 - Conclusões.}

A definição do registro de autorização para operaçōes nas colônias, a definição da sintaxe para um relacionamento de interface e a restriçāo do relacionamento triplo, são algumas importantes contribuiçōes deste trabalho para o MRO como um modelo de dados.

O conceito de distribuição no MRO adquire uma conotação diferente do modelo convencional. Os tipos de ligação entre a base original e a cópia no MRO, estabelecem uma semântica de distribuição que atende mais facilmente a um ambiente de desenvolvimento de projetos do que atende apenas a coexistência dos dados, que é a característica predominante do modelo distribuído de bases de dados convencionais. Assim, aspectos que são importantes em aplicaçōes convencionais, tal como Atomicidade e Serializabilidade das transaçōes passam a nāo ser vitais, sendo em alguns casos contraproducentes. Por exemplo, a atomicidade de uma transação longa obrigaria a desconsiderar-se toda uma operação de integração, se houver conflito em uma de suas operações, o que poderia significar a desconsideração de meses de trabalho. Assim o sistema admite que a atomicidade seja violada, integrando-se o que é possível, deixando de integrar as informaçōes que geram conflitos. A Serializabilidade também é desconsiderada quando o tipo de ligação entre original e cópia é independente, porém essa ligação atende a situaçōes onde o controle de concorrência pode ser resolvida "externamente" entre os projetistas. Operações de atualizações em dados que ainda devam ser acessados por outros aplicativos podem ser realizados quando o tipo de ligação é isolado, causando com isso a possibilidade de que sejam lidos dados que já estão em processo de modificação, porém com isso, evita-se impedir o acesso, mesmo para leitura, a dados que podem sofrer um processo de atualização muito longo.

Neste trabalho buscou-se tornar um problema complexo que é a distribuição de um modelo que tem uma grande representação semântica, em aspectos mais simples, que pudessem ser abordados em detalhes. Para isso, a operação de distribuição foi desmembrada em diversos processos bem localizados. Primeiramente dividiu-se em três processos mais genéricos: separação, manipulaçāo e integraçāo. Posteriormente, na seção 5.3 cada um desses processos foram tratados de modo específico. Com isso, o problema inicial de distribuição de uma base de dados voltada ao suporte de ambientes de projeto foi dividido em um conjunto de problemas bem menores, e foi empreendida sua análise. $O$ resultado dessa análise procura atender a um espectro bastante amplo de 
necessidades dentro desse domínio, embora evidentemente existam situações não tratadas. De qualquer maneira, o particionamento e a modularidade que se buscou para a solução proposta, permitem afirmar que, mesmo as necessidades não atendidas pela soluçāo adotada podem ser analisadas e resolvidas com muito mais facilidade, como conseqüência do trabalho efetuado, uma vez que tornou-se possf́vel localizar com maior precisão, onde qualquer nova operação, ou alteração das operações já tratadas, devem ser empreendidas. 


\section{BIBLIOGRAFIA}

[BERNSTEIN_80a] Bernstein,P.A.; D.W. Shipman ; J.B. Rothnie Jr. - "Concurrency control in a system for distributed databases (SDD-1)", ACM Transactions on Database Systems 5:1, 18-25, 1980.

[BERNSTEIN_80b] Bernstein,P.A; D.W. Shipman. - "The correctness of a concurrency control mechanism in a system for distributed databases (SDD-1)", ACM Transactions on Database Systems 5:1, 52-68, 1980.

[BERNSTEIN_81] Bernstein P.A.; N. Goodman. - "Concurrency control in distributed database systems", Computing Surveys 13:2, 186-221, 1981.

[BIC_86] Bic, L; Gilbert, J.P. - "Lerning from AI: New Trends in Database Techonology", IEEE Computer, Vol. 19, NRO. 1, 44-54, January 1986.

[CALÔNEGo_91] Calônego Jr., N. - "Desenvolvimento de um Núcleo Multi-Usuário para um Sistema de Gerenciamento de Base de Dados Orientada a Objetos", Dissertação apresentada ao ICMSC-USP para obtençāo do títilo de mestre, Agosto 1991.

[CASANOVA_84] Casanova,M. A.;A.V. Moura. - "Princípios de Sistemas de Gerência de Banco de Dados Distribuídos". Texto apresentado na Quarta Escola de Computaçāo, IME-USP, 1984.

[CERI 84] Ceri,S.; Pelagatti,G. - "Distributed Databases: Principles and Systems". MacGraw-Hill, New York, (1984).

[DATE 88] Date, C.J. - "Banco de Dados (Tópicos Avançados)" Editora Campus, Rio de Janeiro, 1988.

[EARL 85] Earl, A. N.; Whitingtom, R. P. - "Capturing the Semantics of an IPSE Database" Data Processing, Vol. 27, Nro. 9, 33-43, November 1985.

[ESWARAM 76] Eswaran, K.P.; et all. - The notions of consistency and predicate locks in a relational database system", Communications of the ACM 19:11, 624-634, 1976.

[GRAY 81] Gray, J.N. et al. - The Recovery Manger of the System R Database Manager", ACM Computing Surveys, Volume 13, Number 2, June 1981, 223-242, 1981.

[HAMMER_79] Hammer, M.; D.Shipman. - "Reliability mechanism for SDD-1: A system for distributed databases", ACM transactions on Database Systems" 5:4, 431-466, 1979. 
[HARTZBAND_85] Hartzband, D. J.; Maryanski, F. J. - "Enhancing Knowledge Representation in Engineering Databases" IEEE Computer, Vol. 18, Nro. 9, 3948, September 1985.

[KATZ_86] Katz, R. H.; Chang, E.; Bhateja, R. - "Version Modeling Concepsts for Computer-Aided Design Databases", SIGMOD Conference, in ACM SIGPLAN Vol.21, Nro. 12, 379-386, 1986.

[KELTER 87] Kelter, U. - "Concurrency Control for Design Objects With Versions in Cad Databases", Information Systems, Vol. 12, Nro.2, 137-143, 1987.

[KIM_91] Kim, Won et all. - "A Distributed Object-Oriented Database System Supporting Shared and Private Databases", ACM transactions on Informations Systems, Vol.9, No. 1, January 1991.

[KOLLER 81] Kohler, W.H. - "A survey of techniques for synchronization and recovery in decentralized computer systems", Computer Surveys 13:2, 149-184, 1981.

[KORTH 82] Korth, H.F. - "Deadlock freedom using edge locks", ACM Transactions on Database Systems 7:4, 632-652, 1982.

[KORTH 83] Korth, H.F. - " Locking primitives in a database system", Journal of the AC̄M 30:1, 55-79.

[LEATH 83] Leath, C.L.; Ollanik, S. J. - "Software Architecture for the Implementation of a Computer Aided Engineering System", in Proc. 20th Design Automation Conference, 137-142, June 1983.

[LORIE_77] Lorie, R.A. - "Physical integrity in a large segmented database", ACM transactions on Database Systems 2:1, 91-104, 1977.

[MARTIN_91] Martin, Bruce E.; et all. - "An Object-Based Taxonomy for Distributed Computing Systems", IEEE Computer Society, special edition of Distributed Computing Systems, 17-27, August 1991.

[NAVATHE_86] Navathe, S. et alli - "Integrating User Views in Database Design", IEEE Computer, Vol.19, Nro.1, 50-62, January 1986.

[ŌZSU_91] Özsu, M. Tamer; Valduriez Patrick - "Distributed Database Systems: Where Äre We Now?", IEEE Computer Society, special edition of Distributed Computing Systems, 68-78, August 1991.

[PAPADIMITRIOU_79] Papadimitriou, C. H. - "Serializability of concurrent databases updates", Journal of the ACM 24:4, 631-653, 1979.

[PIZZIGATTI_90] Pizzigatti, P. L.; Takai, O. K.; Traina Jr., C. -"Uma linguagem de Consulta para o GEO/MRO", Notas do ICMSC, Outubro de 1990. 
[RIES_77] Ries,D.R.; M. Stonebraker. - "Effects of locking granularity in a database management system", ACM Transactions on Database Systems 2:3, 233-246, 1977.

[RIES_79] Ries,D.R.; M. Stonebraker. - "Locking graularity revised", ACM Transactions on Database Systems 4:2, 210-227, 1979.

[SEGEV 89] Segev, Arie; Park Jooseok - "Updating Distributed Materialized Views", IEEE Transactions on Knowledge and Data Engineering, Vol.1, Nro.2, 183-184, 1989.

[SIMON 83] Simon, R.L - "CAD/CAM - The Foundation for Computer Integrated Manufacturing", in Proc. 20th Design Automation Conference, 686-700, June 1983.

[SINGHAL 90] Singhal, Mukesh - "Update Transport: A New Technique for Update Synchronization in Replicated Database Systems", IEEE Transactions on Software Engineering, Vol.16, Nro.12, 1325-1336, 1990.

[SKEEN 83] Skeen, D.; M. Stonebraker. - "A formal model of crash recovery in a distributed system", IEEE Trans. on Engineering 9:3, 219-228, 1983.

[STONEBRAKER_76] Stonebraker, M.; et all. - The design implementation of INGRES", ACM Transactions on Database Systems 1:3, 189-222, 1983.

[SU_86] Su, S.Y.W. - "Modeling Integrated Manufacturing Data with SAM" IEEE Computer, Vol. 19, Nro.1, 34-49, January 1986.

[TRAINA_86] Traina Jr.,C. - "Máquina e Modelo de Dados Dedicados para Aplicações de Engenharia", Tese apresentada ao IFQSC-USP para obtenção do Título de Doutor, Dezembro 1986.

[TRAINA_88] Traina Jr., C.; Slaets, J. F. W. - "Um Modelo de Representaçāo de Objetos", in Anais do $3^{\circ}$ Simpósio Brasileiro de Banco de Dados, Recife, 227-242, Março de 1988.

[TRAINA_91a] Traina Jr., C.; - "GEO: Um Sistema de Gerenciamento de Bases de Dados Orientado a Objetos - Estado Atual de Desenvolvimento e Implementação", in Anais do VI Simpósio Brasileiro de Banco de Dados, Manaus, maio de 1991.

[TRAINA_91b] Traina Jr., C.; Camolesi Jr.,L. - "Gerenciamento do Esquema e Acesso Concorrente em um Sistema de Base de Dados Orientado a Objetos", a ser publicado.

[TRAINA_91c] Traina Jr., C.; Biajiz, M. - "O Modelo de Representaçāo de Objetos: Conceituação e Desenvolvimento", a ser publicado. 